\title{
INTRODUCTION
}

\author{
BY \\ COMMANDER W.M. BISSET \\ SENIOR STAFF OFFICER SA NAVAL MUSEUMS
}

The first narrative of the South African Naval Forces during the Second World War was written by Cdr H.R. Gordon-Cumming, OBE for the Union War Histories Section in the Office of the Prime Minister and appears to have been completed in December 1950. A number of chapters from this work were included in War in the Southern Oceans 1939-45 which was published by Oxford University Press in 1961. In December 1967 a shortened version of Cdr Gordon-Cumming's narrative, which he entitled Brief History (Sea) was included in a book duplicated on a Roneo machine, A Short History of the SA Navy, compiled by Lt (now Cdre, Retired) A.P. Burgers for the SA Navy's Directorate of Personnel at Naval Headquarters.

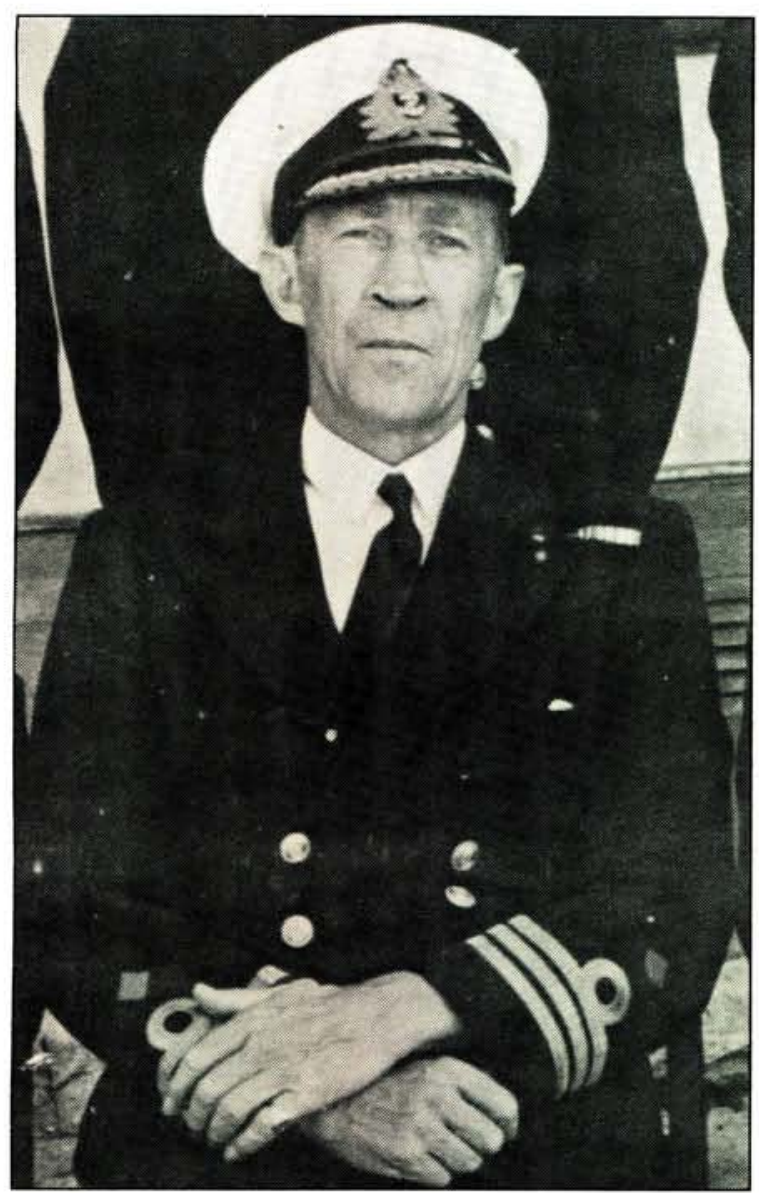

Cdr H.R. Gordon-Cumming OBE. (Photo supplied by SA Naval Museum)
In 1973 the SA Navy celebrated its 50 th Birthday by publishing a history entitled South Afrlca's Navy, The First Flfty Years which was compiled under the direction of Cdre J.C. Goosen, SM. This work contains extracts from Cdr Gordon-Cumming's Brief History (Sea).

Cdr Gordon-Cumming served in ships in the Royal Navy's Africa Station at Simon's Town between 1921 and 1927 and was Senior Staff Officer to RearAdmiral Hallifax when the Seaward Defence Force (SDF) was established. In November 1941 he was appointed South African Naval Officer-in-Charge of the Durban Detachment of the SDF. For his valuable services during the Second World War, he was created an Officer of the Order of the British Empire and awarded two King's Commendations.

The unpublished chapters of Cdr Gordon-Cumming's narrative fill important gaps in our naval history, so it is fitting that some of these should be published in this special edition of MILITARIA, which appropriately appears as the South African Navy celebrates its 70th Birthday. 


\section{UNPUBLISHED CHAPTERS FROM THE OFFICIAL HISTORY OF THE SA NAVAL FORCES DURING THE SECOND WORLD WAR}

BY CDR H.R. GORDON-CUMMING, OBE

\section{CHAPTER I}

\section{EARLY SDF ORGANISATION : JANUARY TO MAY 1940}

On 15 January 1940, the Seaward Defence Force (SDF) formally took over from the Royal Navy the responsibility for operating the minesweeping and anti-submarine services, the Port War Signal Stations and the Examination Services at Cape Town, Durban, Port Elizabeth and East London. The Commanding Officers of these port Divisions - soon afterwards renamed "detachments" to conform with military usage had been appointed a fortnight earlier and were $\mathrm{Cdr}$ J. Dalgleish, Lt Cdr H.B. Stocken, Lt Cdr G.V. Thomas (Commander RNVR, retired) and $L t$ C.S. Peers, respectively.

The size of their commands strictly complied with instructions, received during the formative period, that numbers were to be kept down to a minimum (as "the total strength of ths SDF was never likely to exceed 500"). At Cape Town, where a minesweeping depot was somewhat grudgingly allowed as a temporary measure while ships were being fitted out, the shore-based personnel consisted of 15 officers, 28 ratings and two civilians; at each of the other three ports there was a total strength of about 30 . The apparently high proportion of officers included four for the Examination Service and two Extended Defence Officers as the bare minimum at each port. The Directorate consisted of four officers and 14 others. The Controller of Stores and Accounts had 18 in his department, including civilian clerks, typists and labourers.

This period was of the greatest value for an administrative "shake-down" most of which could, with greater foresight, have been much simplified by pre-war planning. The Military Discipline Code (MDC) of the Union, quite apart from its excessive inconvenience as a volume, was new to everyone and did not cover naval requirements, especially as regards summary punishments. It was found, for instance, that a few comparatively minor offences in a flotilla might put it out of action for several days while the cases were dealt with by the ponderous machinery of military law, including voluminous paper-work and courtsmartial convened by the local army Commander. In the other direction, a case actually occurred of a Commanding Officer being incapable of taking his ship to sea owing to drunkenness one of the few offence for which the MDC permits a summary punishment and being fined ten shillings. This remarkable sentence was made possible by the fact that it concerned a Skipper (Patrol Section RNVR) graded by the army as an "other rank". Soon after, all skippers were made Sublieutenants (ie commissioned officers). Amendments, applicable only to the 
SDF, were therefore made then and later with the result that, eventually, the powers of summary punishment were greater, on the whole, than those permitted by the Naval Discipline Act.

Recruiting at first took place only at Cape Town where volunteers were interviewed by an officer of the Directorate. As only about 180 posts in the establishment remained vacant, (the shortage was at first 51 officers and 134 ratings, of which most of the former were later obtained by promotion in the Förce) it was decided to go slowly and to confine immediate acceptances to men with professional experience, some of whom were still coming forward. As a result, numerous applicants, very promising in other respects, could only be placed on a waiting list and many of these joined other units before the SDF could take them. No assistance was then given by the military recruiting organisation, even when required; ex-postal telegraphists, for instance, badly needed for training as naval W/T operators, were debarred from joining any unit but the Corps of Signals. During the first two or three months, therefore, new entries were not sufficiently numerous to cause a serious problem; they were mostly accommodated for training, though in considerable discomfort, in the ships already at sea.

It had already been laid down that the uniform of officers and men would be very similar to that of the Royal Navy, the only differences being that buttons, when available, would be of a slightly different design, that the capribbons of ratings would carry the letters "S.D.F.", and that officers and men would wear the "orange flash" prescribed for all members of the UDF who were prepared to serve outside the Union - an addition which, it was decided, was least unbecoming to naval uniform when worn on the sleeve. Personnel on loan were permitted to wear the uniform of the services from which they came. However, in so far as the ratings were concerned, these instructions had to defer to the fact that new uniforms of any kind were practically unobtainable; many of the men wore plain clothes for months after joining and even boiler-suits and oil-skins were in extremely short supply. The shortage was aggravated later by the unforseen expansion of the Force, so that it was fully two years before all recruits received complete kits on joining.

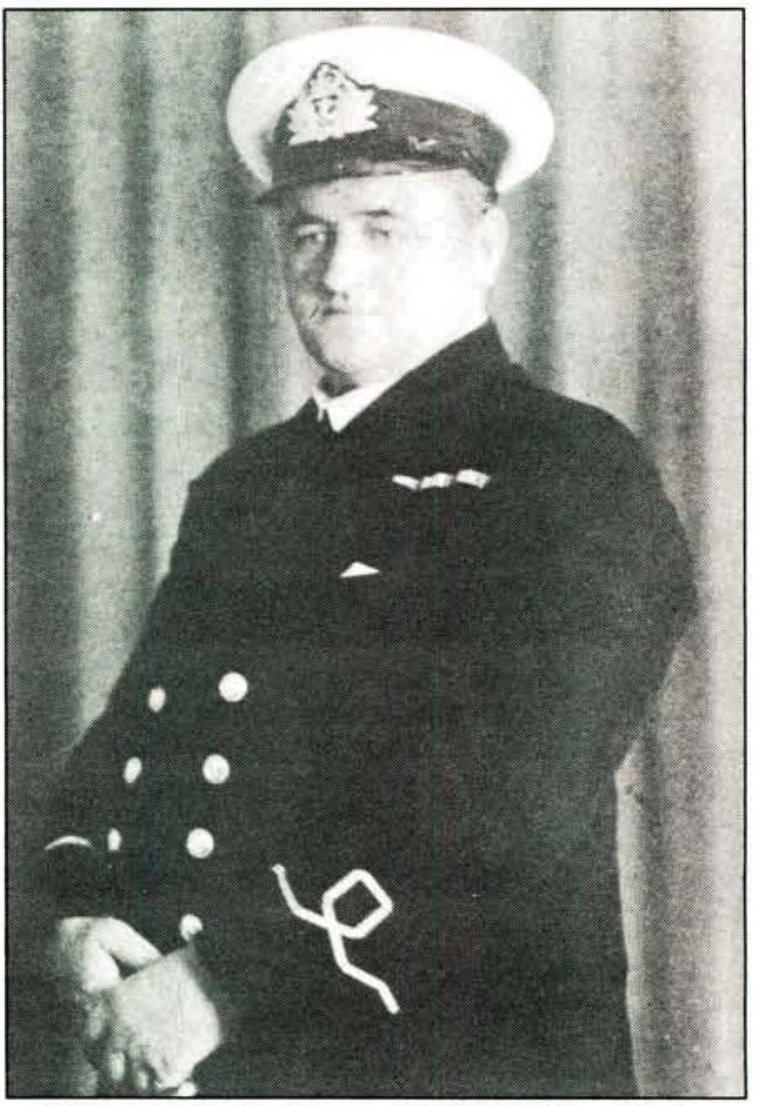

Skipper R. Palmer, RNVR (SA). (Note Uniform)

The ships were designated "His Majesty's South African Ships" (HMSAS) and were ordered to wear the White Ensign (for recognition purposes) as well as the flag of South Africa. The question how service "anywhere in Africa" should apply to the SDF was decided by a Special Proclamation which laid down that: "... any portion of the Seaward Defence Force, or any member thereof, may be employed on any ship commissioned by the Secretary for Defence for purposes of defence, when such ship is in any waters surrounding South Africa, whether within or outside the territorial waters of the Union."

With regard to general administration, the Director had previously stressed the necessity of his being given a very free hand - at least until the personnel side became sufficiently stabilised to draw up a seniority list of officers and rosters of ratings under their various categories. This was agreed to and for the first year or more Defence Head- 
quarters exercised only a remote control over appointments, advancements and promotions, provided that the last two fell within the authorised establishments.

\section{MINESWEEPERS AND A/S VESSELS}

The 15 minesweepers, with complements of 18 or 19 , were distributed as follows: at Durban, Port Elizabeth, East London and Simon's Town, two at each port; at Cape Town, seven. Of the latter, one or two were being could be altered without difficulty and this was, in fact, done later when mines were found well outside the 100-fathom line. The anchorages outside the harbours were also swept periodically.

As regards anti-submarine measures, the minesweepers when fully converted for war, were each armed with one 12-pounder gun, one or two Lewis MGs and two mounted depth-charges. As no form of asdic was fitted, they could be used only for surface patrols, but even as such they were of some deterrant value against submarines.

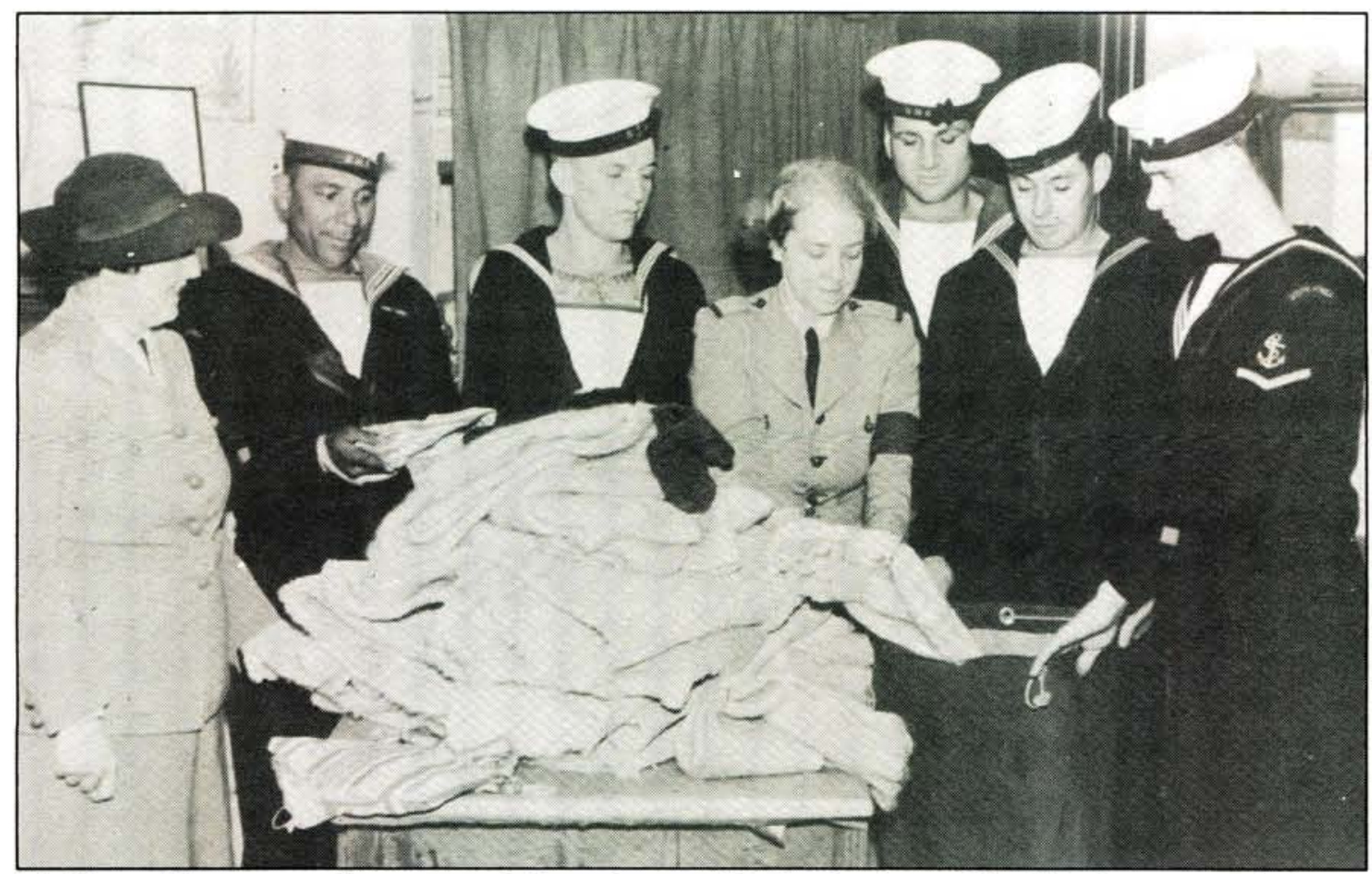

SA Naval Forces ratings receiving sheepskin jackets and knitted garments from Mrs EIsie Skaife (left) and a SAWAS helper. Orange diamond badges can be seen on the sleeves of two of them.

armed and another, the Fishery Research ship AFRICANA, which had the most suitable accommodation, was available for instructional purposes. The two Simon's Town minesweepers were placed under the operational control of the Royal Navy while on this duty. These $\mathrm{M} / \mathrm{S}$ flotillas were already carrying out daily sweeps of the Searched Channels which had a width of two miles and a centre line running directly from a point near the harbour entrance to another point, arbitrarily selected, near the 100-fathom line, a distance varying from 22 miles at Cape Town to seven at Durban. As there are virtually no outlying navigational obstructions off the South African ports, the direction, width and length of these channels
By the middle of January 1940, an A/S officer with a staff of eight $\mathrm{RN}$ ratings, four asdic sets (Type 123) and $A / S$ instructional equipment had arrived in this country. The officer, Lt R.C. Burton $R N$, had a dual appointment, being on loan to the Seaward Defence Force and also on the staff of the SNO, Simon's Town; his staff, who were on loan to the SDF, included specialists in depth-charge maintenance.

Early in February the two most suitable trawlers, MOOIVLEI and BLOMVLEI, arrived at Simon's Town for conversion to $A / S$ vessels and in the middle of March the first batch of SDE officers and men began their A/S course. These courses were held at Simon's 


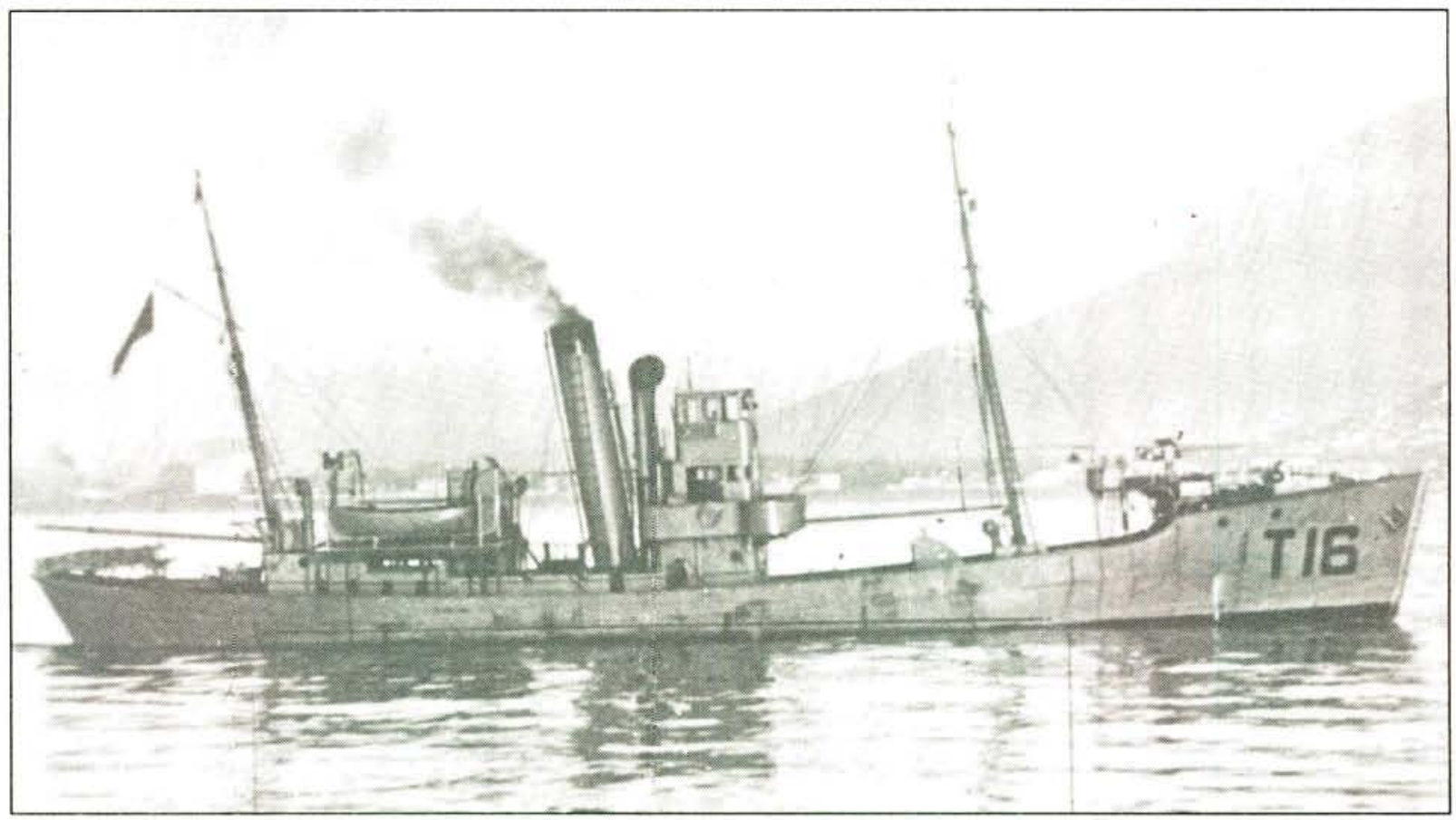

HMSAS MOOIVLEI.

Town until suitable accommodation for a small $A / S$ school could be found in Cape Town docks. As soon as the two ships were ready for sea in April, the practical part of the course was carried out in them; but it was not until early in 1943 that two non-operational submarines were made available at Cape Town and Durban for instructional purposes.
Early in February 1940, the SAR \& H administration informed the Secretary for Defence that they could no longer cope with all of the conversion work required for SDF vessels. Authority was therefore given to place future work with certain private firms under the supervision of Admiralty Overseers. Owing to the more technical and confidential nature of their conversion,

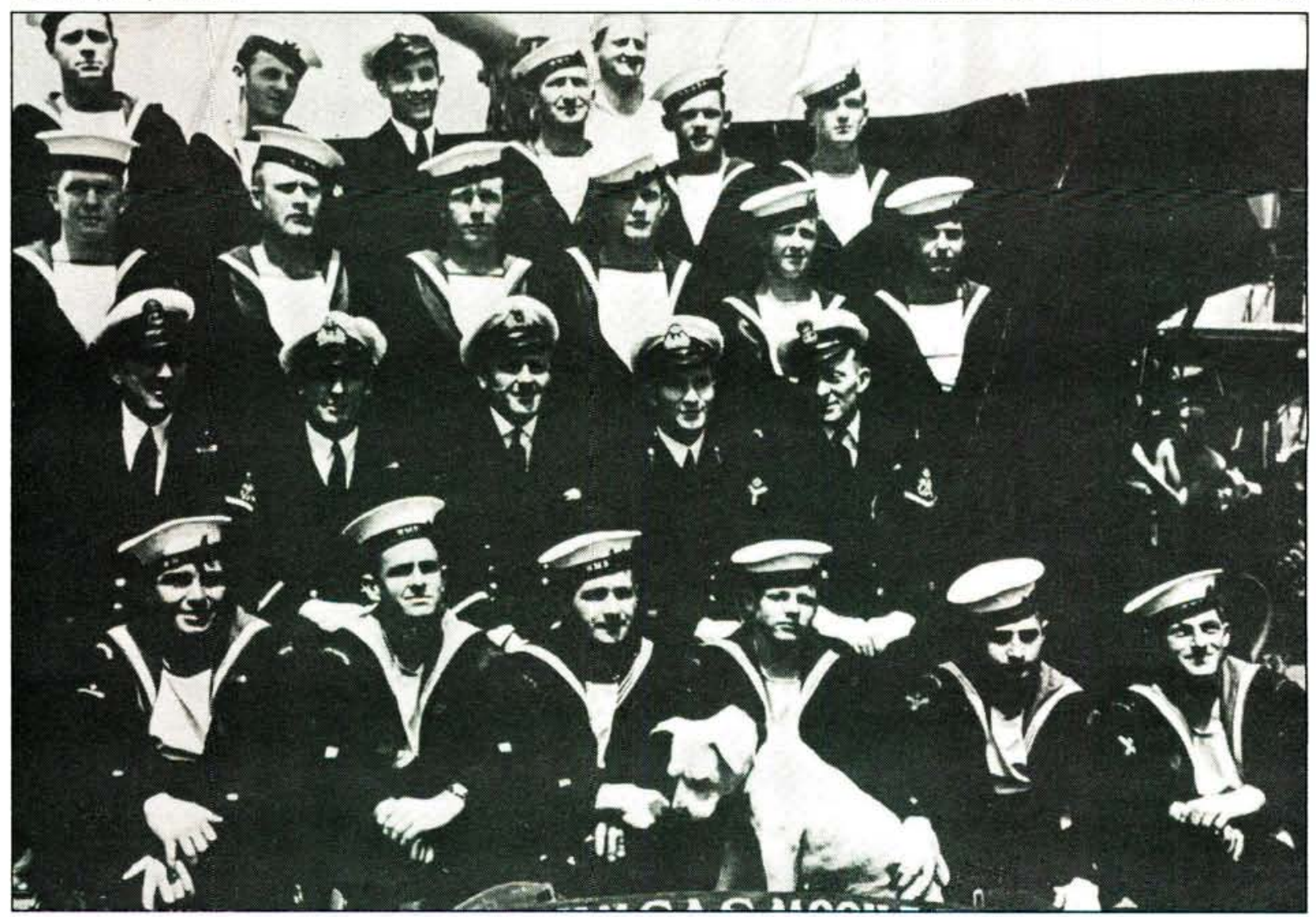

The Ship's Company of HMSAS MOOIVLEI circa 1944. 
A/S vessels continued to be fitted out at Simon's Town, but the Admiralty, a few months later, agreed to this work being carried out by private firms also.

When the whaling fleets returned from the Antarctic at the end of the season, immediate steps were taken to acquire some of these larger whalers and approval was obtained, on 3 April, to requisition five of the Hektoria Company's vessels. These, though by no means the best of the Antarctic whalers, had a nominal speed of 13 knots and were expected to be a decided improvement on any of the ships then in service. As the authorised number of 21 vessels already had been requisitioned, it was arranged that five trawlers would be returned to the fishing industry as soon as the HEKTORS had been converted.

\section{THE EXAMINATION SERVICES}

Of the four Examination Vessels, whose duties were non-combatant, two were chartered complete with their crews and two were operated by the SAR \& $H$, so that SDF personnel were not required for this service. (In 1942, by which date the work of the Examination Services at Cape Town and Durban had greatly increased, the two vessels at these two ports were taken over, both for manning and maintenance, by the SA Naval Forces; they were each provided with two complete crews, working in 24-hour spells.)

\section{THE INCREASE OF PERSONNEL}

The first increase in the number of ships (from 21 to 32 ) required an additional 300 officers and ratings, bringing the total strength to about 900 and when the number of ships was further raised soon afterwards to 40 , with 52 as the eventual total, it was apparent that the personnel side, in all its aspects, would require drastic re-organisation.

Fortunately there were still more than enough volunteers for naval service. Arrangements were made whereby they were handled by the Army Recruiting stations which passed them on to the SDF officer at the nearest port, for selection, before sending them to Cape Town for enrolment. A retired naval officer in Johannesburg rendered valuable unpaid assistance in this respect by interviewing and reporting on volunteers in the Reef area. While the raw material thus obtained was most satisfactory both in quantity and quality, there was a shortage of men with technical experience - eg as engineers, telegraphists and cooks. As the complete training of these would obviously be more difficult to arrange and take much longer than that required for seamen and stokers, the early manning of the ships largely depended on the provision of men with some previous specialised knowledge of the kind required.

The exact establishment of personnel took many months to work out in detail; the numbers for the additional ships' companies were easily calculated, but the requirements of extra shore-based personnel to administrate, feed, pay and supply the ships and their crews could not be decided at once and were mostly arrived at by the economical but inefficient process of keeping the departments in question increasingly under-manned until they could no longer cope with the work.

Owing to delays of this nature and to other operational developments which began soon after, the establishment of personnel never remained static for any length of time, so that the figures for October 1940 - 183 officers and 1049 men (about double the original number) - are of temporary interest only. This number included a "training reserve", of $10 \%$ - well named because training requirements were all that it allowed for; all the other ineffectives men in hospital, on leave, in detention, in transit and so on, amounting to at least a further $25 \%$, had to be borne by the ships and shore stations which were therefore continuously short of complement.

The sudden influx of recruits raised the question of shore accommodation for which no provision previously had been considered necessary. So urgent was the matter that for some months several railway carriages, shunted into the Table Bay docks near where the ships lay, were used for the purpose. Soon after, arrangements were made 
to acquire a cargo store in Table Bay docks and it was fitted out as a naval barracks, to take about 50 men, by October 1940. Certain offices of the Cape Town detachment, for which there was now insufficient space in Seaward House, were also transferred there. Though it formed a useful stopgap, this building was unsuitable in many ways and, as to space, the detachment soon outgrew it. But, it was not until the middle of 1942 that sufficient living accommodation was provided by the completion of a new block, known as BONAVENTURE I, near the western end of the new basin. The original barracks, then named BONAVENTURE II, was thereafter used solely for offices and workshops. In July 1940 the Directorate moved out of Seaward House to more spacious quarters and soon after, the Controller of Stores and Accounts, who had been one of the first to apply for a large increase of staff, did the same. ed very well. Now, however, with the RNVR also enrolling many new recruits, the facilities at the training bases were severely strained; the shortage of instructors and equipment entailed larger classes, with a corresponding lack of individual supervision and loss of efficiency. There was particular difficulty over signalmen, many of whom had to be returned from sea for more thorough training; this became so necessary that in May 1941, special courses for signal and $W / T$ ratings began at the East London RNVR base. In July 1940, a series of training classes for ratings recommended for commissioned rank began; the first took place at the Port Elizabeth training base but subsequent courses were carried out afloat in HMSAS AFRICANA, in the Cape Town - Saldanha area. Eleven men at a time took the seven weeks' course and those who failed to pass for commissioned rank were, in some cases, advanced to Acting Petty

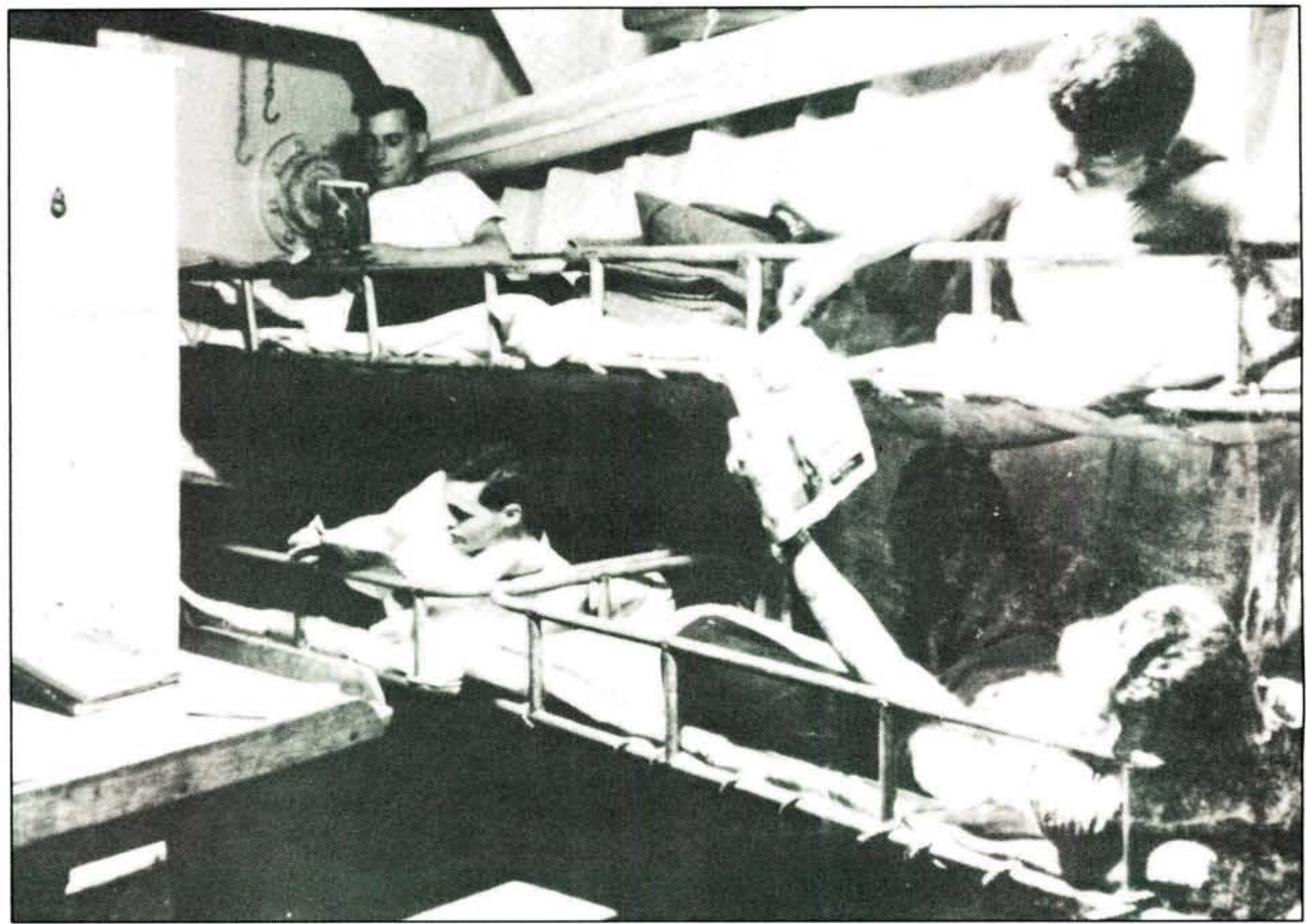

A mess deck in one of our "little ships". (Photo: SA National Museum of Military History)

It had been arranged, when the SDF was first formed, that its shore training should be provided by the existing RNVR organisation at its bases concurrently with RNVR classes and, with the small numbers involved, this had work-
Officer and re-examined for officer's rank later.

In addition to the large number of trained men required to fill the new establishment, the RNVR (on loan) 
personnel had to be considered. A fair number of these had, by now, chosen to join the SDF for good and the remainder had been given no definite date of release, but many were now applying for this and it was most desirable to comply with their choice of service as soon as possible; in doing so, there was naturally most delay in the cases of specially trained men.

Amongst recruits, mention must be made of the excellent material provided by the training ship GENERAL BOTHA. The majority of her ex-cadets, who had joined the merchant service for good, were still serving in it or in the Royal Naval Reserve; but many others, who had left the sea and found shore employment in this country, now came forward and the high percentage who became officers or made good in other respects demonstrated the value of the early discipline and training provided.

\section{SDF DEVELOPMENTS AT DURBAN}

During the first six months after the birth of the Seaward Defence Force in January 1940, its small expansion was confined to Cape Town. Not only was it the headquarters, where conversion work could be carried out under the immediate eye of the Directorate, but it was also the nearest port to the centre of hostilities. Further, its approaches, including the Agulhas Bank, were for topographical reasons, the most vulnerable part of the Union's coastline to enemy minelaying.
At the three other commercial ports, the strengths of the SDF detachments remained at the bare minimum, the size and importance of Durban being balanced by its greater distance from German bases.

The situation altered with the entry of Italy in June, followed by the closing of the Mediterranean and the steady increase of traffic round the Cape. Chiefly owing to fuel-supply difficulties, Port Elizabeth and East London were not fully used until much later in the war, so that all the extra shipping was handled at the two larger ports. Of these, Durban possessed the only drydock in Southern Africa capable of taking a battleship and therefore, if only as a growing naval refitting base, promised to become of great strategic importance. With several whalers already fitting out there, the local SDF Detachment began an expansion which, accelerated by the Japanese threat later on, was to continue for four years.

Although the post of CO Durban Detachment, was not officially advanced to that of a Commander until the middle of 1941, Cdr H.R. GordonCumming was sent to take over from Lt Cdr H.G. Stocken, who was transferred to East London in November 1940. Until October 1941, when a depot was completed at Congella, the Durban headquarters was in Tribune House, under the same roof as the Royal Navy; the ships were berthed, where possible, near " $Q$ " shed, part of which was used as a store. 


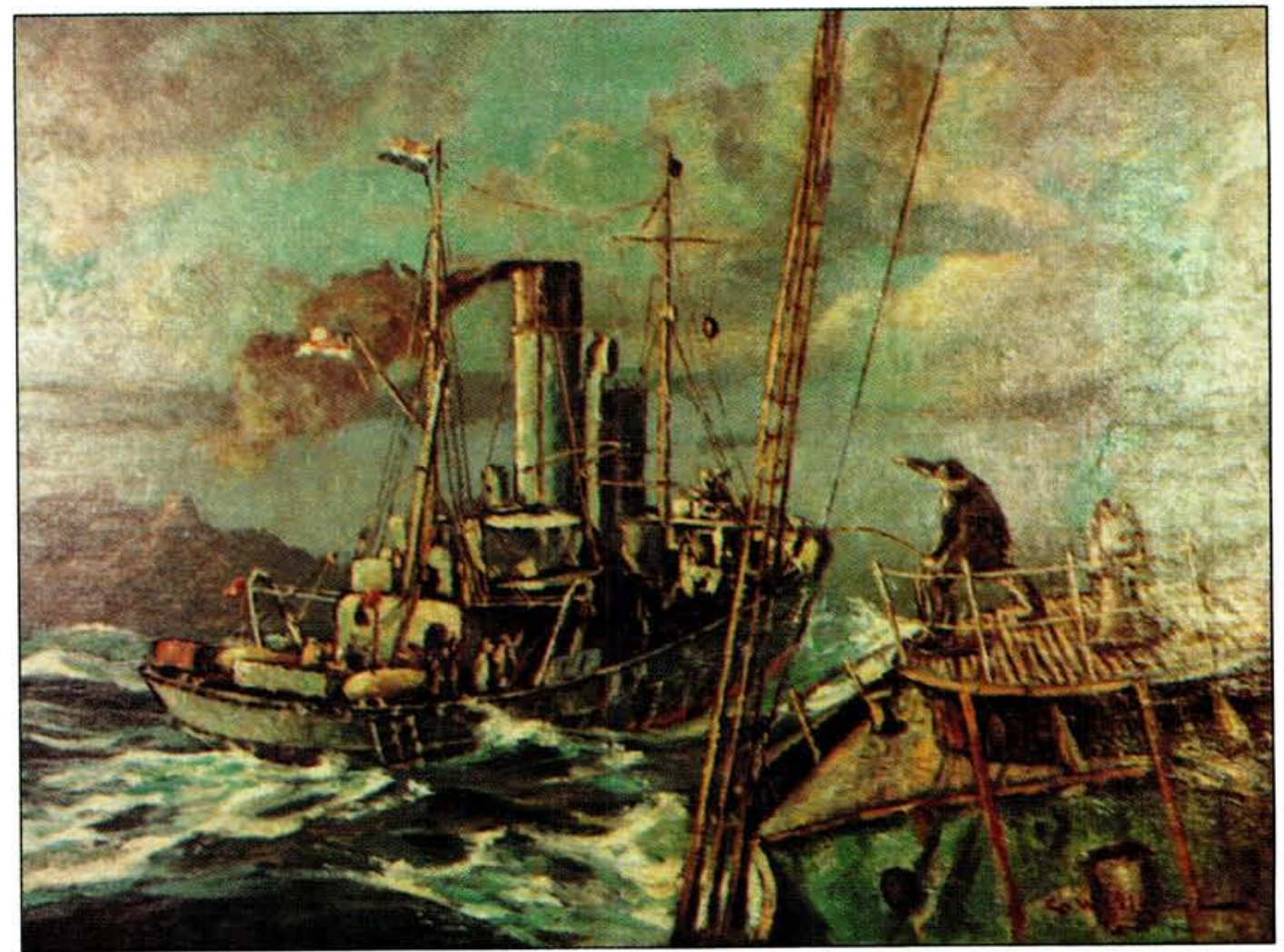

"Passing the Sweep"' oil painting by George William Pilkington. The setting is Table Bay. A light rope, thrown from one minesweeper to another, was used to haul the heavy sweepingwire across the gap between the two ships and so position it for minesweeping. The sweep was designed to catch the cable of a moored mine and thus bring it to the surface.

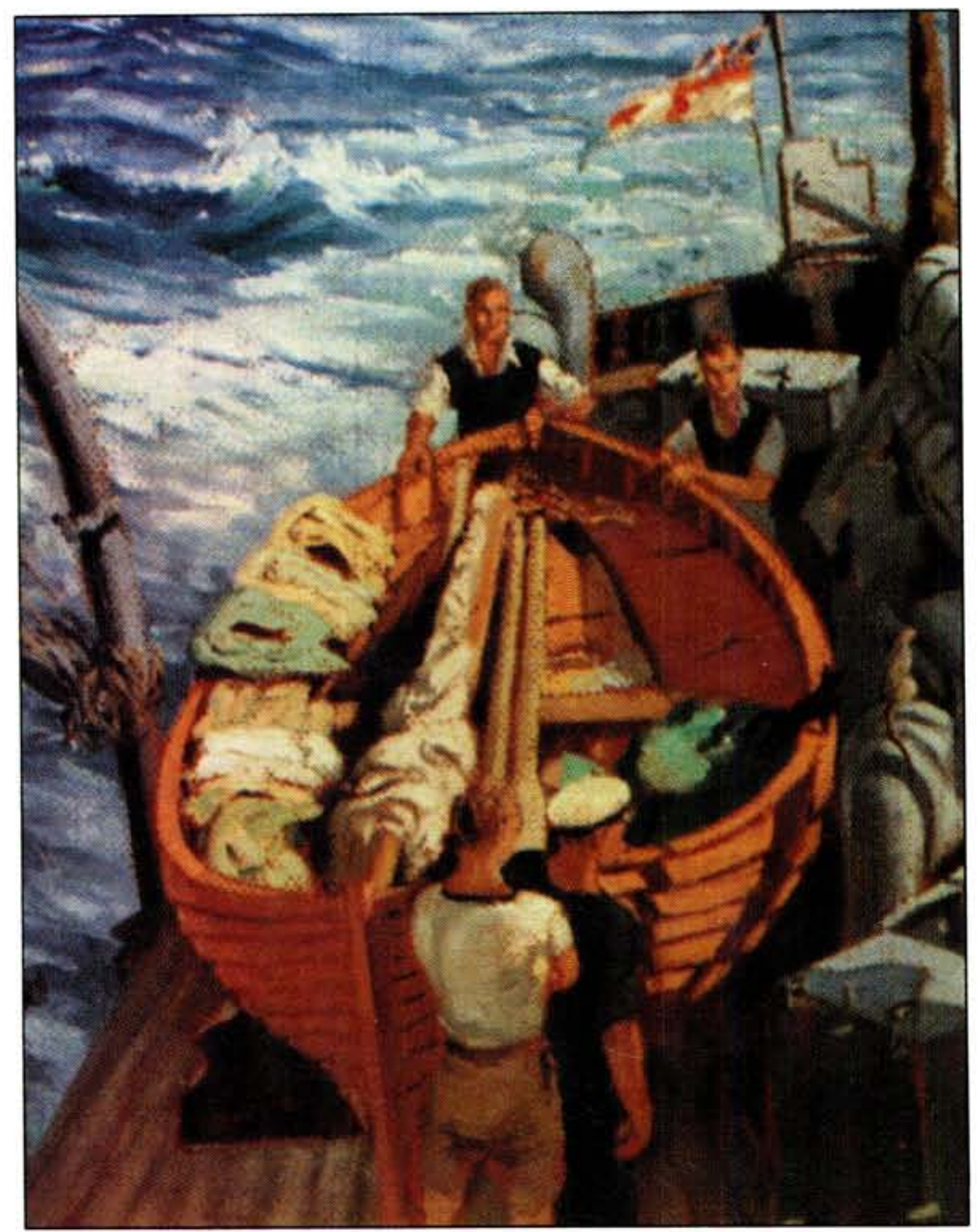

Photo's supplied by SA

National Museum of Military History

"Quiet Afternoon with Convoy", oll painting by Alfred Gordon Taylor. The opportunity is being used to check the lifeboat and its supplies and equipment. 


\section{GENERAL MATTERS IN 1941}

\section{WALVIS BAY, OFFICERS' APPOINTMENTS, THE FITTING OUT OF MINESWEEPERS AND THE INCREASE OF PERSONNEL}

\section{THE WALVIS BAY DETACHMENT}

Although the original War Plan had included Walvis Bay as a defended port, it did not become one in the full sense on the outbreak of war; the conditions did not warrant it, nor were sufficient ships or naval personnel available. On 4 September, however, four 60-pounder field-guns were installed and were then used to cover the occasional ships which arrived until the port authorities had boarded them. Later in the month the Commander-inChief, South Atlantic, asked the Union Government whether Walvis Bay might be used for bunkering merchant ships so as to relieve the congestion at Freetown (Sierra Leone) which had resulted from the increase of traffic via the Cape. Owing to the strong German influence in the Walvis area, there were doubts at first as to the safety of the port for shipping, but the request was subsequently acceded to and arrangements were made for the handling of up to three ships a day.

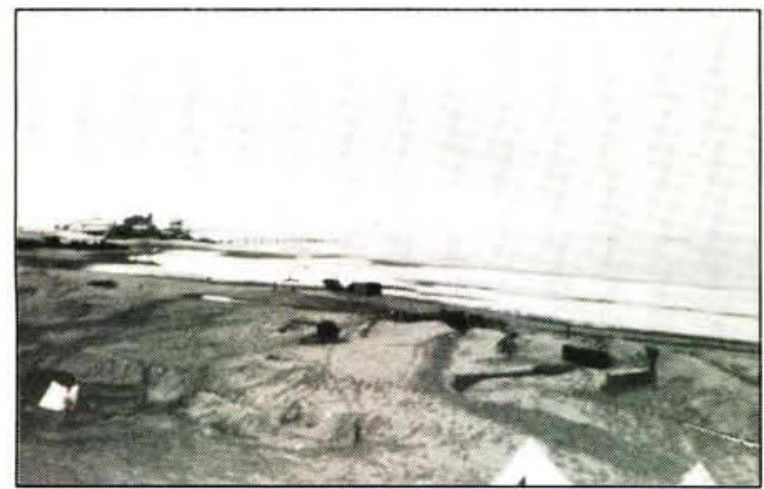

Walvis Bay cira September 1939. (Photo supplied by Brig L.G.F. Wolf, SM, MC)

A fifth SDF Detachment was therefore established at Walvis Bay in January 1941. The tender CLARA arrived there from Cape Town with stores and personnel on 16 January and on 19 January the $M / S$ vessels ARISTEA and GOULDING began the routine sweeping of the Searched Channel which ran due west to the 70-fathom line, about 21 miles from Pelican Point. Later, two alternative channels were instituted, one of them dog-legged and both reaching the 70 -fathom line a few miles farther north. Owing to the small number of ships calling, no examination vessel was provided, this duty being carried out by the local minesweepers. Later, the field-guns were replaced by two 12-pounders and two 6 -inch guns on fixed mountings.

At first the accommodation ashore was primitive and even after this had been improved upon, recreational facilities were few and the general living conditions unpleasant. The personnel were therefore relieved rather frequently and no less than eight officers commanded the detachment at different times.

At the end of 1943, when the post of the senior military officer was reduced in rank, the SA Naval Officer-in-Charge became the Fortress Commander. The Royal Navy was represented by a Naval Liaison Officer and a small Naval Control Service staff until April 1944. Then, owing to the small number of ships calling, it was arranged that the SA Naval Officer-in-Charge should take over these duties also and the RN personnel were withdrawn.

Happenings in the Walvis area include the arrival of a U-boat which sank two ships in that latitude towards the end of 1941 and the stationing of two A/S vessels in that area for a short time; the wreck of DUNEDIN STAR and the rescue of the survivors and salvage of a part of the cargo; the sighting of a German submarine 20 miles from the port in May 1944; and one or two searches for the survivors of torpedoed ships off South West Africa.

No mines were laid in the area, but German records reveal that Raider $G$ 


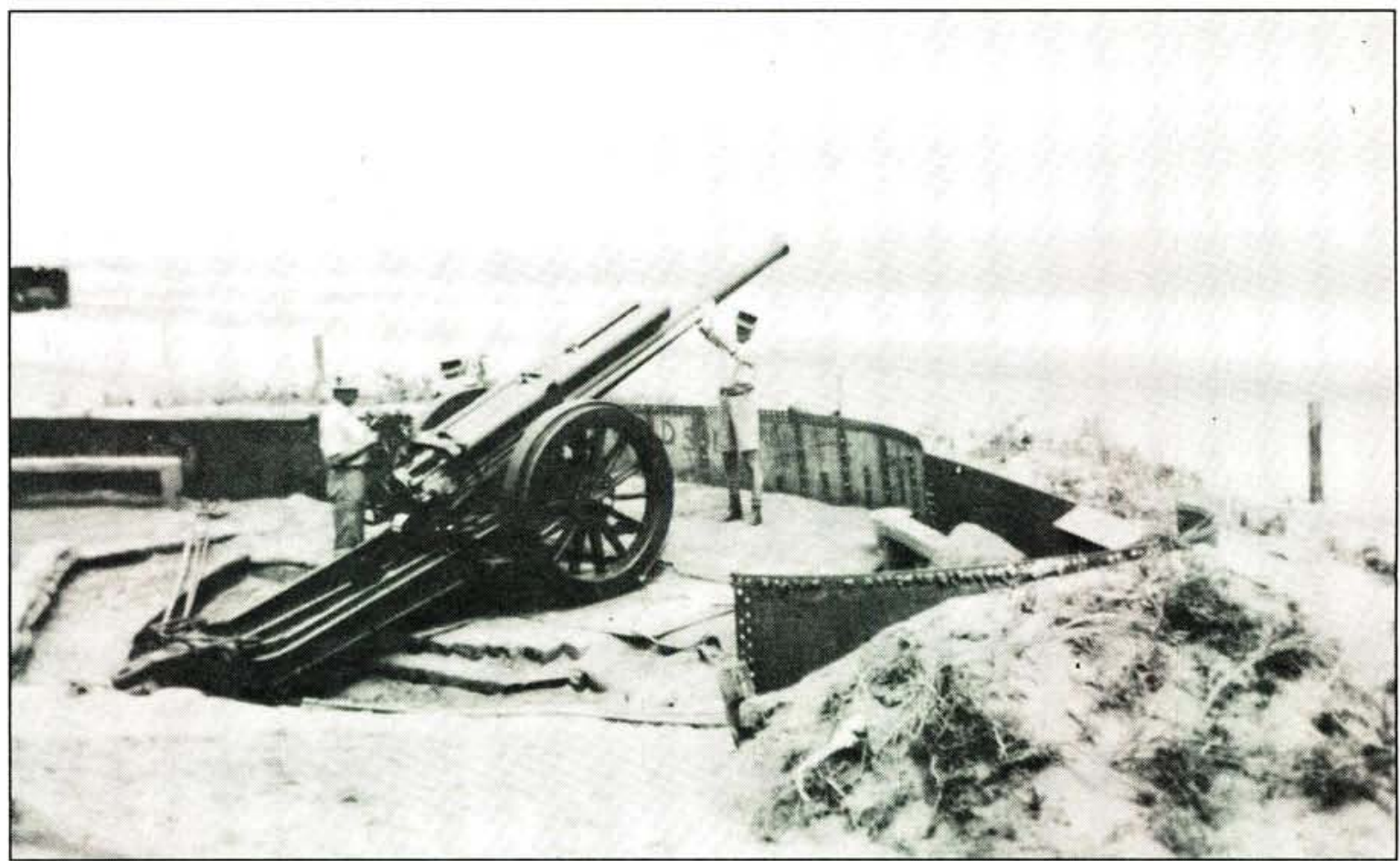

One of the four 60-pounder field guns which were mounted in temporary emplacements at Walvis Bay on 4 September 1939. (Photo supplied by Brig L.G.F. Wolf, SM, MC)

(KORMORAN; Schiff 41) intended to do so on her way to the Pacific in 1941. This was cancelled on account of weather conditions.

\section{DEATH OF ADMIRAL HALLIFAX CAPTAIN DALGLEISH BECOMES DIRECTOR}

In March 1941 the Director inspected the new detachment at Walvis Bay.

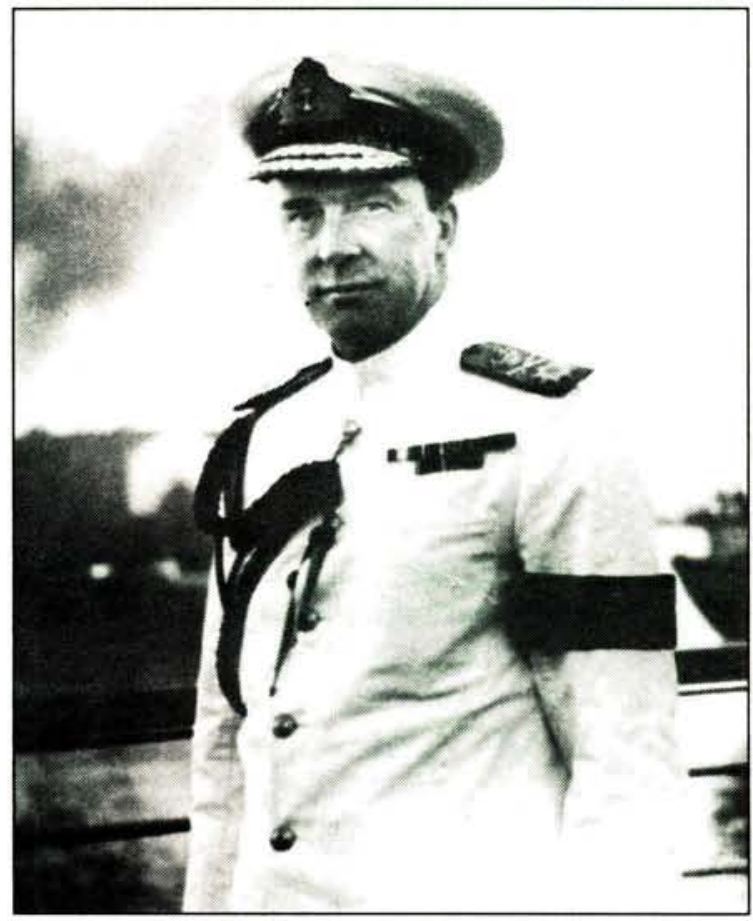

R Adm G.W. Hallifax, CMG.
On 28 March the aircraft in which he was returning to Cape Town struck the crest of a rocky ridge near Baboon Point, 40 miles north of Saldanha in thick weather; the plane was totally destroyed and there were no survivors. In this sudden and tragic way, Admiral Hallifax was lost to the service for which he had done so much, just when he was beginning to see the results of his early perseverance.

Car J. Dalgleish, the senior Permanent Force officer in the SDF, was then appointed Director with the rank of Captain. Considering that in 1941 the Defence Department would have had considerable difficulty in "importing" a suitable senior officer, even if it had wished to do so, it was indeed fortunate that the Directorship should have fallen, almost automatically, into such capable hands. The early impetus given by Adm Hallifax was never relaxed and his work was continued and completed in a manner which provided the best possible epitaph to his memory.

Although the new Director took over after most of the initial difficulties of creating a new service had been overcome, his task of completing the programme of expansion, even as then authorised, was no light one. As will be 


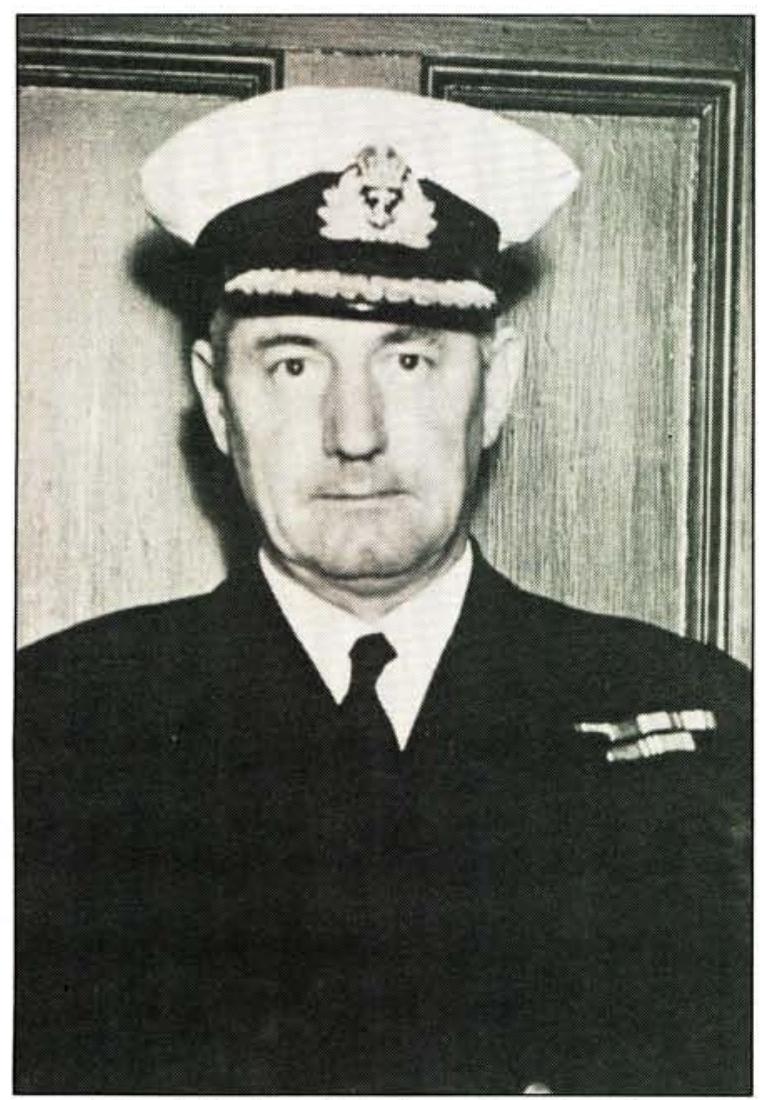

Capt (Iater Cdre) J. Dalgleish.

seen, this was soon to involve far more than the conversion and manning of more $A / S$ and $M / S$ vessels; the fact that the war would obviously be a long one, during the greater part of which the Cape route was likely to remain of the highest importance, had already caused the Union Government to accept several additional naval commitments, such as degaussing facilities (a protective measure applied to ships as a safety precaution against magnetic mines). With the entry of Japan at the end of the year, these "side-lines" - mostly of an amphibious nature - grew and multiplied until Allied victory was well in sight in 1944. Throughout the year 1941, however, the fitting out of newly requisitioned vessels continued to be the most important technical item on the programme of expansion.

\section{FITTING OUT OF MINESWEEPERS IN 1941}

In January 1941, $24 \mathrm{M} / \mathrm{S}$ vessels were in service, three were being converted and several more were about to be requisitioned. Shortly afterwards, matters were complicated by the Admiralty recommending protection against ground mines of either the magnetic or acoustic type. As these would be effective only in comparatively shallow water and the enemy was not in a position to use aircraft (the usual method) for laying them, this type of offensive was less to be feared than the laying of moored mines, owing to the much bolder tactics required on the part of the minelayer.

The danger, however, could not be ignored and in March authority was given for the fitting out of six vessels as LL minesweepers - these to be included in and not in addition to, the established total of $37 \mathrm{M} / \mathrm{S}$ vessels. The Admiralty, meanwhile, became in urgent need of vessels of this type for the Mediterranean and in May the Union Government agreed to provide and man eight. Although these ships (together with the three $A / S$ vessels already serving with the Royal Navy and a fourth earmarked to replace the lost SOUTHERN FLOE) were, at about this time, given the status of a "reserve" additional to the existing establishment (52 M/S amd $A / S$ vessels), they received priority over the provision of magnetic sweepers for local defence which had therefore to be deferred if only because of a shortage of equipment.

Even then it was feared that eight conversions of such a novel and highly technical nature could not be taken on simultaneously in this country without much delay, so four of the ships were only degaussed, manned by the SDF and left this country on 30 July 1941 for fitting out in the Middle East. The next two ships were completely fitted out in the satisfactory time of four months, including trials, at Durban and sailed from there in November. The last two ships, taken in hand at Cape Town early June, did not sail for the Mediterranean until April 1942.

Meanwhile, to bridge the gap in local waters, provision was made for skidtowing - a method which, at the best, was suitable only for dealing with ground mines laid in harbour entrances and other sheltered areas. By the end of 1941, 21 magnetic skids had been constructed; six were allocated to Cape Town and three each to Durban, East London, Port Elizabeth, Simon's Town and Walvis Bay. This number was provided owing to their being "expendible"; they cost about $\$ 500$ each. 
However, the provision of vessels capable of towing and operating the skids, for which six of the trawler-type ships were chosen, was not so simple as it had first appeared. Although structural alterations were not very extensive, degaussing was necessary as well as the provision of special generators and other fittings not then obtainable in this country. There was so much delay over this that the first three ships were not completed until January and February 1942.

In the meantime adverse reports had been received on skid-towing elsewhere and it had become doubtful whether this method would be practicable in South African waters; it was therefore decided to convert four of the ships completely with LL (MarkV) installations, leaving them still capable of skid-towing and for this, they were taken in hand two at a time. Of the other two ships of the original six, one remained as a skid sweeper only and the conversion of the other was cancelled. It was arranged that both the LL (Mark V) and skid-sweepers should also be able to use Oropesa $\mathrm{M} / \mathrm{S}$ sweeps.

In the latter half of 1941, five whalers; two recently requisitioned and three already in service as $\mathrm{M} / \mathrm{S}$ vessels, were also earmarked for fitting out as LL (Mark III) minesweepers similar to those sent to the Mediterranean and the conversion of four of them had begun by the end of the year. The position in January 1942 as regards minesweepers of all kinds was therefore as follows:

Fitting Out: Two trawlers being fitted as skid and LL (V) sweepers; three nearly completed as skid-sweepers only. Two new whalers being fitted as LL (III)s. Two $\mathrm{M} / \mathrm{S}$ whalers being re-converted as LL (III)s. One new whaler being fitted for $M / S$ to replace an older $M / S$ vessel earmarked as the fifth LL (III).

In Service: Six vessels of the MC Flotilla, 18 port minesweepers disposed as follows: Cape Town (including Simon's Town), eight; Durban, four; Walvis Bay, two; Port Elizabeth, two; East London, two. (Owing to the number of re-conversions in hand, this total of $24 \mathrm{M} / \mathrm{S}$ vessels in service was two less than it had been 9 months earlier - a temporary reduction which was made full use of by increasing the number of men under training ashore.)

The above total of 34 minesweepers of all kinds, fitting out and in service, though three short of the number authorised, was never exceeded chiefly because by this time there were no more suitable vessels available in the country after making provision for the full number of $15 \mathrm{~A} / \mathrm{S}$ vessels.

It may here be stated that no ground mines were ever laid in South African waters. The five LL (III) whalers were completed between March and November 1942 and did little beyond periodical sweeping exercises; their stability having been reduced during their reconstruction, they were seldom employed on extraneous duties at any distance from the ports. The four LL (V) trawlers came into service between June 1942 and March 1943; being "dual-purpose", they assisted in the routine M/S sweeping of the Searched Channels.

\section{ADDITIONAL OFFICERS' POSTS : 1940 AND 1941}

After the expansion of the Force began in the middle of 1940, certain shore-going officer's posts were gradually added to the establishment. On the detachment staffs, the earliest of these were for two officers for legal and secretarial work at Cape Town and Durban. In the latter half of 1940, also, two new posts on the Directorate were created. One of these was for an officer in charge of Confidential Books; these were mostly obtained on loan from the Admiralty who naturally made it a condition that their rules for the security of CBs should be strictly adhered to. The other new post was for a signals officer.

When the SDF was formed, there were only four engineer officers (Lt Cdrs), one for each detachment. At Cape Town, the DEO at first was largely employed on conversion work, but decreasingly so as more vessels came into service and required his attention for normal repair work; elsewhere, the DEOs were also responsible for stores and victualling (for which a stores officer was allowed at Cape Town 


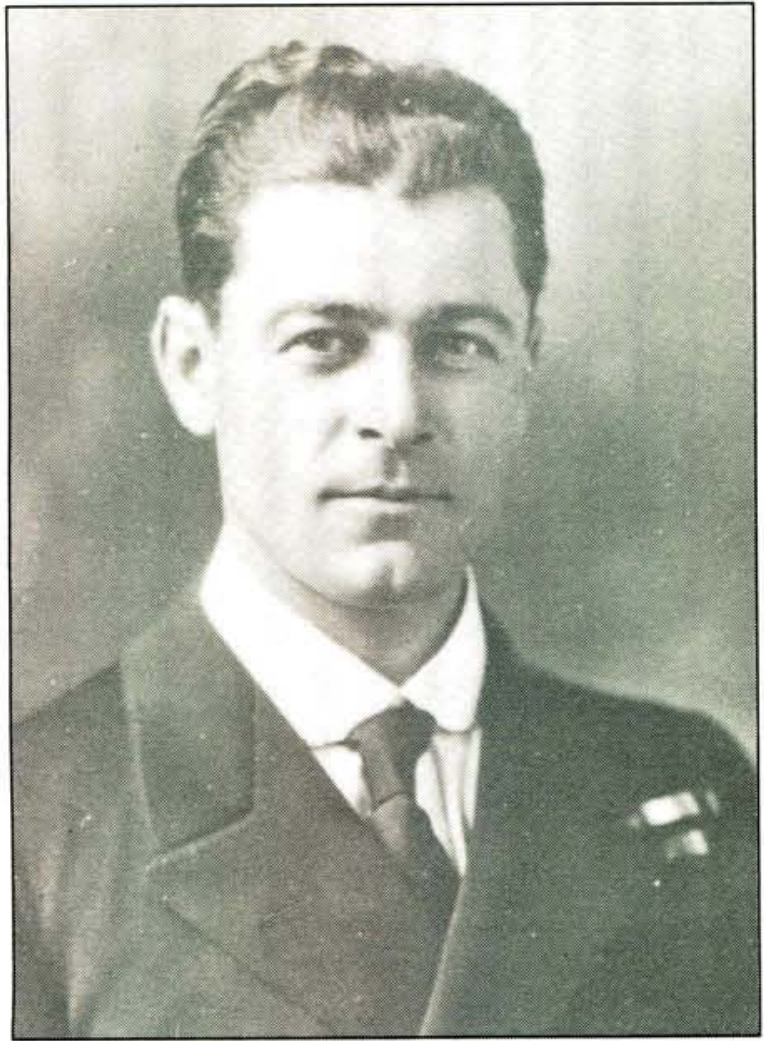

Lt Cdr (later Cdr) L.E.S. Napler, DSO.

only). The earliest increase in this branch resulted from the decision that all $A / S$ vessels and the Senior Officers' ship of the Mine Clearance Flotilla, should have officers as chief engineers. The first engineer sub-lieutenants received their commissions in the later part of 1940 and four of them sailed in the "Southerns" for the Mediterranean at the end of the year. During the early part of 1941 the fitting out of vessels was handled directly by the Deputy Director, Lt Cdr L.E.S. Napier, assisted only by $\mathrm{Cdr}$ Dalgleish who acted in an advisory capacity on account of his early experience and was later to become Director.

\section{PROVISION OF EUROPEAN (WHITE) RATINGS IN 1941}

Perhaps the most urgent problem which faced Capt Dalgleish soon after his assumption of directorship was that of providing and training ratings of all branches, as quickly as possible, to fill the hundreds of new posts created by the decision, arrived at in April 1941, that SDF ships serving in the Mediterranean should be regarded as an additional, but fully manned reserve. At that time there were only three of these - the A/S vessels of the SOUTHERN class - and the total strength of personnel was then only 150 below establishment, but nine more ships were authorised in May. Further, the trend of events pointed to yet more requirements long before the existing ones were likely to be satisfied. By September 1941 the establishment had risen to 288 officers and 2175 men, the numbers then serving being 216 and 1427 .

The employment of Cape Coloured men did much to make up the shortage of non-specialist junior ratings and released a large number of Whites for other work and training. Every new ship would require at least two officers, three petty officers (including a sufficiently experienced engineer to take charge of that department), a signalman and a telegraphist; and the provision of LL minesweepers entailed the introduction of two new rates electrical artificers and wiremen - the former soon to be required also for the maintenance of electrical installations on shore.

As a result, the first naval recruiting drive took place in the latter half of 1941. As well as the Corps of Signals and other UDF units being asked to permit suitable volunteers to transfer to the SDF, articles appeared in the leading newspapers emphasising the more pressing requirements and making a special appeal to employers of "key men" to release recruits with the necessary technical qualifications. In December, permission was obtained for a small naval recruiting party of one officer and two leading ratings to visit the Youth Training Brigade Camp at Potchefstroom and to tour the Rand area, which from that time onwards, provided a large proportion of the new entries. Taken as a whole the results of this drive were successful and the ships were duly manned as they came into service.

\section{FIRST EMPLOYMENT OF COLOUREDS}

When the two smallest trawler-minesweepers, ARUM and NERINE were first requisitioned by the $R N$ in 1939, the firemen and deckhands were Cape Coloureds. As the RNVR Patrol Section was open to Europeans (Whites) only and no other experienced trawlermen 
were available, the men were retained on Merchant Service Agreements and proved quite satisfactory for work in local waters. When the SDF took over soon afterwards this arrangement remained in force; for adminsitrative convenience the two ships were kept in the same detachment and formed the Port Elizabeth M/S Flotilla for the next two years or more.

In April 1941, when serious future manning difficulties first threatened, the Director asked for authority to recruit 173 "Non-Europeans" (although they were officially given the comprehensive name of Non-Europeans, only Cape Coloured personnel were employed then and later) - sufficient to provide non-specialist seamen, stokers, cooks and stewards, together with a $10 \%$ reserve, for $12 \mathrm{M} / \mathrm{S}$ vessels. With ARUM and NERINE providing a satisfactory precedent as to the suitability of the men, there were strong arguments in favour of this, including that of the general manning position in the country; even if the large naval shortage could be made up entirely by Europeans in time to man the ships, other services would suffer. Also, as the only untapped source of sea-faring recruits lay among the Coloured fishing communities, it was apparent that they would require less initial training than European (White) landsmen.

The scheme was at once approved in principle and soon afterwards was extended to the entry of more men, not necessarily with sea-going experience, for employment in naval shore establishments, which would release Europeans for more responsible duties, technical training and so forth. There was then some delay while the conditions of service, provision for extra accommodation and other details were worked out, so that it was not until June that formal authority was received for the recruiting of Coloured personnel and for their attestation for service anywhere in Africa. The men were to be quite distinct from the Cape Corps, UDF, and as they were to be interchangeable with Europeans (Whites) of certain categories and do similar work, it was decided that they should receive the same pay. This undoubtedly had its effect; for the first year or more the number of applicants was far in excess of requirements, so that those accepted were of a high average standard.

The first batch of about 50, were entered in August 1941 and commenced disciplinary courses at the Cape Town and Port Elizabeth RNVR Training Bases, of which the latter afterwards became the main centre of Coloured training. The September course included the 22 civilian deck-hands and firemen from ARUM and NERINE, now attested for the first time, who were relieved for this by some of the men trained in August, but otherwise the proceeds of the earlier courses had to be employed mainly on shore - first at Cape Town and then, at Durban when the new detachment headquarters and depot were completed there in October. This was because the seamen gunner, signalman and telegraphist carried by each minesweeper, though of the grade of $A B$, had to be Europeans and therefore required separate accommodation which entailed structural alterations. These could be put in hand only when the ships were laid up for major alterations or periodical refits, so that it took many months to effect all the changes of crews originally allowed for. The first ship so converted was GOULDING in September and the other coal-burning minesweepers followed at intervals of three or four weeks.

\section{LATER DEVELOPMENTS}

It may here be said that the employment of Cape Coloured ratings at sea proved so successful that, with European manning difficulties continuing, their numbers and those of the ships they manned were greatly increased. By the end of 1943, 22 port minesweepers (91 M/S and three LL) as well as two examination vessels and several smaller harbour-craft and part Coloured crews (out of a minesweeper's complement of about 22, 13 were Coloured); the two coal-burning $A / S$ vessels MOOIVLEI and BLOMVLEI had been manned by them for a time; and they had also been borne in the salvage ship GAMTOOS, but in this duty they had proved less satisfactory and had recently been withdrawn after nearly a year's service in the Mediterranean. 
For work in the minesweepers - mainly uneventful, but requiring considerable stamina - the Cape Coloured men were, if anything, an improvement upon the Europeans whom they replaced. Of the latter, it must be remembered, all the more intelligent and well-behaved men either received early advancement or else were drafted off for training as signalmen, telegraphists, seamen gunners and submarine detectors after a few months hardening at sea; this left only inexperienced or otherwise inferior men, especially in the port minesweepers, whose duties were considered less important than those of the A/S vessels and the Mine Clearance Flotilla. Further, the Coloured ratings appeared to suffer less from staleness and, with proper handling, took a great pride in their ships in which there was a marked average improvement in smartness and cleanliness.In the shore establishments, the number of Coloureds rose correspondingly; as well as supplying working-parties, cleaners and messengers (who, being trained seamen or stokers, were available as reliefs for those at sea), most of the junior cooks' and stewards' posts were filled by them. At the degaussing ranges at Cape Town and Durban several Coloured ex-schoolmasters and ex-clerks were employed on routine technical duties such as blue-printing, drawing electrical diagrams and the collecting and filing of ships' records - work which they performed with care and precision.

In October 1943, out of a total strength of about 4000 , there were 830 Coloureds in the Service. Their recruiting then ceased, to be opened subsequently from time to time only to make up temporary shortages, but it had amply served its purpose; by no other means could the extra ships have been manned in time - and only just in time, as it happened - to assist in combating the German minelaying and submarine offensives of 1942 and later. 


\title{
DEGAUSSING, MINE DISPOSAL AND NAVAL FIXED DEFENCES (OTHER THAN BOOMS)
}

\author{
THE SOUTH AFRICAN DEGAUSSING RANGES : EARLY ARRANGEMENTS
}

The enemy's use of magnetic mines in Europe resulted in the receipt of the following Admiralty message by the Senior Naval Officer, Simon's Town, dated 4 June 1940 :

"It is desired to establish degaussing open ranges at certain Dominion and Indian ports. Information is requested whether Dominion and Indian naval authorities will undertake their establishment and operation. Instruments and stores not available locally will be supplied from United Kingdom. Instructions for laying already promulgated. Personnel for ranges one lieutenant, one civilian electrical officer and assistant, three recorders WRNS, two signalmen. In addition, one physicist per Dominion with necessary qualifications to analyse and make recommendations. Ranges in order of priority Halifax, Cape Town, Bombay, Sydney. Duplex later. If proposals concurred in Senior Technical Officer should report to Superintendent of Degaussing at Admiralty for training without delay, travelling by air."

It should here be noted that the provision and maintenance of the suggested degaussing range had no direct connection with South Africa's defences, but was rather, a link in a world-wide service for the protection of shipping against magnetic mines. By accepting the cost of this commitment, which it did on 31 July after more information had been provided, the Union Government made its first external contribution towards the general Allied war effort. At first there was a question whether the Royal Navy should lay and operate the range, but it was soon decided that the SDF would do so, the Admiralty providing only such technical equipment and initial assistance as might be required.

As, even in Britain, this was quite a new branch and there had not as yet been time to train specialists to supervise the laying of DG ranges elsewhere, the services of Professor B.L. Goodlet, of the University of Cape Town, were obtained as Technical Adviser. He left for Portsmouth in August and spent several weeks absorbing the necessary first-hand knowledge and practical experience before returning to this country in November.

\section{FORMATION OF THE ELECTRICAL BRANCH : SEAWARD DEFENCE FORCE}

As the SDF then possessed no technical officers, Prof Goodlet had to recruit and train his own staff who thus became the first members of the SDF Electrical Branch, formed at the end of 1940 with an initial establishment of three officers and nine ratings. With the many additional technical commitments which were accepted later, the branch expanded steadily, especially after the installation of $A / S$ Fixed Defences in 1942 and 1943. Qualified divers were soon required and members of the branch were so trained at Simon's Town, but it was three years before the Defence Department approved of the payment of an allowance for this specialised and often dangerous work.

Prof Goodlet himself continued to serve as a civilian until December 1941 when he received a commission as Electrical Commander, SDF. Later he was awarded the OBE for his services. In April 1943 he was seconded for special duties under the Admiralty and was succeeded by $\mathrm{Lt}$ 
Cdr A.L. James who had done valuable work as his chief assistant.

\section{LAYING OF THE CAPE TOWN RANGE}

The only suitable position for the range was found to be close to the eastern shore of Robben Island, so that the site for the instrument rooms, offices and living accommodation had to be on the island itself. This not only more than doubled the estimated initial cost of £3 500 owing to the necessity of providing special supplies of electric power and fresh water, but also resulted in complications and delays chiefly connected with transport and communications. In spite of the work of installation being new to all those immediately concerned and of delays caused by the dilatory peace-time methods still adhered to by the Government Departments concerned, matters were sufficiently advanced by the end of February 1941 for the range units to be laid. For this, a ship of considerable length was required and the SNO, Simon's Town arranged for HM Cruiser DELHI to come to Cape Town for the purpose after preparations had been made on board her by Simon's Town Dockyard for the handling and accurate lowering of the units. Two sets of units, for ranging shallow and deepdraught ships, were laid on 26 and 28 February, the ship having to be rigidly moored, head-and-stern, for each operation. For each range there were 12 units, placed 30 feet apart for the deep range and 20 feet apart for the shallow range. The minesweeper CRASSULA, which had been specially prepared for the purpose, was then used for laying the electrical cables which connected the units with the shore station - an operation which required good weather as well as good seamanship.

The range opened on 6 June, but a series of winter gales then caused many cable breaks and much interference with ranging, so that only 12 ships were dealt with in that month. By the end of 1941 the number had risen to nearly 100 per month. This was more than the existing staff could cope with and in November additional posts for two officers and six ratings were approved; the former were Range Pilots, occupied solely on liaison work with the masters of the ships being ranged. The number of ships dealt with in the first 12 months was 1145 .

\section{DEGAUSSING : LATER DEVELOPMENTS}

Even with the Table Bay range working at full capacity, it was soon unable to deal with the greatly increased volume of shipping using the Cape route and so, at the end of February 1942, the Admiralty asked for the provision of deep and shallow DG ranges at Durban. After negotiations had been completed regarding the cost, position and additional personnel required, $\mathrm{Cdr}$ Goodlet went to Durban and was so successful in pressing on with the preliminary work that the units for the deep range were successfully laid immediately south of the Umgeni River mouth in July, the large SAR \& $H$ dredger RIETBOK being used for the purpose. The site, in common with the rest of that coast, was found to be too exposed to swell for the laying of a shallow range which was therefore cancelled. A series of delays then occurred owing to bad weather, to break-downs of the Admiralty vessel employed on laying the cables and to over-meticulous government control over all expenditure. In November, when the cable-laying was at last taken in hand, it was found that most of the buoyed "pigtails", rising from the units, had been fouled by shipping or otherwise lost and that the whole range therefore had to be relaid. In the meantime, the buildings had been finished and the range came into operation on 20 February 1943. By the end of the year 80 ships per month were being dealt with.

By the end of February 1945, 3034 ships had been ranged at Cape Town and 1292 at Durban. If taken together, the total of 27 million gross tons was the third greatest output in the world, coming next to those of the Thames and Clyde ranges.

Deperming: In the latter half of 1942, a unit for deperming small ships was installed at Durban where the barge GILBERT OF COLCHESTER supplied the 
battery power and a total of 125 ships was thus given protection. In 1944 a borehole range, for deperming large ships, was added.

Note: The fore and aft component of the ship's magnetism, not conveniently neutralised by DG circuits, could be removed by wrapping several electric cables completely round the ship (over and under her) and passing a high current through them momentarily so as to magnetise the ship in the opposite sense to its original fore and aft magnetic polarity. The current was supplied from storage batteries in an auxilliary vessel placed alongside for the purpose. To control the deperming operation, measuring instruments had to be placed under the ship, either slung from ropes or permanently installed in boreholes in the sea bed where the ship could be berthed directly over them. At the Durban borehole range there were 58 measuring units, each separately connected with an instrument room on the adjacent jetty. It should be noted that degaussing and deperming were not merely for local defence, but were part of a world-wide service for the protection of Allied shipping of all kinds. After being so treated, ships compasses were usually affected and their correction was an additional service eventually provided by the SANF.

Some months earlier Cdr Goodlet had made tentative suggestions on the subject, but on 15 June, just after the first of the 1942 mines had come ashore, with the probability of more to follow, he put up a definite proposal to the Director that the SDF should assume the same responsibilities as the Admiralty (in the UK). Assuming that this work would be the responsibility of the Electrical Branch, he further asked permission to call for two officer volunteers, who with himself, would receive an instructional course from the RMS specialists of the RN.

This proposal was referred to and approved by the General Officer Commanding Coastal Area, who arranged for a Defence Force meeting to be held, followed by discussions with the SAR \& H Administration. On 28 August the re- sponsibilities of the three fighting services were promulgated, those of the SANF being for the disposal of all mines on Union territory not owned by the Admiralty and all bombs or shells found below high water mark, on merchant shipping, on property occupied by the SANF and in SAR \& $H$ areas. Meanwhile, the suggested RMS training had begun on 29 June, followed by that of additional volunteers later in the year. Finally, the police and Civilian Protection Corps were given the necessary information and orders for the identification and reporting of washed-up mines, by means of lectures, printed instructions and line drawings of the types of mines likely to be encountered. In March 1944, owing to the RN specialists being more urgently required elsewhere, it was agreed that the SANF would also be responsible for Admiralty property (owned or rented). Early impetus was given to these arrangements by the stranding of numerous mines on the south-west coast in the latter half of 1942. The first of these arrived at Thorn Bay, about 50 miles north of Cape Columbine, and was dismantled by the RMS officers on 12 June. Cdr Goodlet was sent to represent the South African authorities and so gained his first practical experience of mine disposal. Later, after the instructional course had begun, the other pupils benefitted in the same way.

Four other mines were dealt with in June: at De Hoek, near Bredasdorp on 14th; near Slangkop, Cape Peninsula on 20th; at Hout Bay, Cape Peninsula on 23rd; and seven miles west of Cape Agulhas on 30th. By the end of September the total had reached ten which had been disposed of as follows: Two dismantled and completely salvaged; four dismantled and then burnt out; four blown up by countermining without being dismantled. The usual procedure was to dismantle a mine if its complete detonation, in situ, might endanger life or property (as in the case of the mine found near Slangkop Wireless Station) or if its appearance promised any novel internal features. A full report on each mine and the method of dealing with it was forwarded to the Admiralty. One of these mines had drifted as far east 
as Humansdorp where it was destroyed on 16 August - the first to be dealt with by the SANF without help or guidance from the RMS officers of the RN.

Between September 1942 and December 1944 only five more mines were found beached, two of them near East London and another near the Great Brak River mouth in the George district.

All of the 15 mines dealt with up to this time had been German types $Y^{x}$ and $V$ (the latter being type $Y^{x}$ modified as an antenna mine), but the last mine to be washed up on the SA Coast was a French mine (Breguet type) which had presumably drifted all the way from northern Madagascar. It was found near Scottburgh in Natal on 11 March 1945 and had to be dismantled owing to the proximity of the railway and power lines.

\section{THE FIRST ANTI-SUBMARINE FIXED DEFENCES : GOODLET LOOPS}

Early in 1942, the British War Cabinet Sub-Committee on Defence Arrangements for the Indian Ocean Area made recommendations for various fixed underwater defences in South Africa. Included in these was apparatus for the detection of midget submarines which might operate against the ports, of which Durban was considered the most vulnerable target. There, the closing of the long entrance channel would have been more easy to effect and would have had more serious consequences than elsewhere. The surface patrols and the Examination Service, backed by the coastal batteries, gave protection against enemy blockships but not against the sinking or stranding of a friendly ship in the fairway. This danger was emphasised soon afterwards by the attacks on shipping in Sydney Harbour and Diego Suarez at the end of May, followed by the known presence of a Japanese surface raider and I-class submarines (either of which might be carrying midget submarines) off the Durban/ Lourenco Marques coast during June and July.

None of the Admiralty-pattern instruments or equipment was then in this country, but the matter was so urgent that $\mathrm{Cdr}$ Goodlet was instructed to do what he could with materials obtained locally. $\mathrm{He}$ had already done some experimental work of this kind, and although dredging operations delayed matters somewhat, his "Goodlet Loops" were working satisfactorily in the Durban entrance channel by the end of October.

The installation consisted of two loops of electric cable, one crossing the channel close to the north pierhead and the other 550 feet up-channel from it. Both were connected with a small control station on the root of the South breakwater where one officer and one rating kept continuous watch. Each circuit passed through a fluxmeter acting upon a photo-electric trigger relay which operated an electric bell when a crossing took place and the system was sufficiently sensitive to detect an 80-foot wooden fishing boat with a steel keel and engine. In the event of an unidentified crossing, the outer loop provided a warning and the inner loop confirmed it. At first, the offensive part of the system was a motor boat provided with five-pound hand charges, in close communication with the control station and at all times ready to slip from her moorings. Owing to the prevailing shortage of personnel she was manned, by day only, by a full-time SANF crew; at night, after the boom had been closed, the SANF Reserve took over this duty. Somewhat similar arrangements were then made for the two harbour entrances at Cape Town.

\section{NAVAL FIXED DEFENCES - GENERAL POLICY.}

Most of the recommended defences, however, were far too elaborate for local improvisation. The installation of additional boom defences, Harbour Defence Asdics of two types, several hundreds of miles of cable for $A / S$ indicator loops and a controlled minefield, together with the shore stations required for their operation, entailed large supplies of technical equipment and stores as well as the services of trained personnel and several specially fitted vessels. 
After some discussion it was agreed that the provision of these defences would be primarily a Union Government commitment but that the Admiralty would give every assistance, both in material and personnel, without charge.

This meant that practically all the technical equipment would be brought from the United Kingdom and installed by R.N. specialists, who would be seconded to the S.A. Naval Forces for the purpose, but that the Union Government would erect the buildings and provide all such other labour and materials as were available in this country. It was also agreed that South African personnel would be trained to take over the installations as soon as they were in full working order, as well as such vessels as would be required for maintenance.

These arrangements, however, were not the cause of the work being somewhat delayed: the Admiralty, whose output of new equipment and trained personnel was then comparatively small, had to give priority to those ports and coasts nearest to the enemy - in Australian waters and the eastern side of the Indian Ocean.

\section{LAYING OF INDICATOR LOOPS AND H.D.A.S (TYPE 131).}

It had been decided early in the year 1942 that the first harbours to be provided with $A / S$ Fixed Defences would be Cape Town, Durban and Saldanha Bay in that order. In April and May the local conditions at those ports were carefully investigated as to their suitability for the intended installations, and a preliminary survey of the area beyond Table Bay anchorage was carried out after the arrival of the cable-laying vessel EMILE BAUDOT on $27_{\text {th }}$ May. In consultation with her captain, Commander Goodlet then drew up the proposed general lay-out of the Cape Town system. This was to consist of four indicator loops, with an average length of four miles each, passing outside Robben Island, between Melkbosch and Clifton. The loops were to be backed by four H.D.A.s (type 131), two to the northeast and two to the south-east of the island, and all of the tail-cables were to be landed on the east side of Robben Island near the site of the proposed control station, the erection of which was authorised by the Union Government in the middle of June.

Early in July, the first contingent of A/S F.D. specialists arrived at Cape Town. The complete team consisted of eight officers (mostly R.N.V.R., United Kingdom) and 57 ratings; its senior officer was appointed A/S Fixed Defence Officer, South Atlantic - to act as A/S F.D. adviser to both the Commanderin-Chief, R.N. and the Director, S.A.N.F.

On 11 th July the proposed lay-out received Admiralty approval and EMILE BAUDOT began to lay the Cape Town loops forthwith. As was to be expected, this was considerably interfered with by bad weather but the system came into full operation on 20th November 1942, towards the end of the first German submarine offensive in these waters. The four H.D.A.s also had been laid and connected up by that date, but two of them broke down almost immediately, owing to the rocky nature of the bottom, and were not replaced.

The installation of the South African loop systems then proceeded slowly owing to cable-laying difficulties. It had been hoped that two vessels would be available, but the locally fitted CECILE MAPLESON proved to be so unreliable that, after a series of breakdowns of her main engines, it was decided to replace her. For this the coaster MEAD was requisitioned and fitted out by the Royal Navy, but she was completed only in time to take over from EMILE BAUDOT which sailed for Colombo in January 1943 after carrying out a preliminary survey at Durban. H.M.S. MEAD then began to lay the Durban indicator loops which formed a rough semicircle, beginning about a mile south of the Bluff and ending seven miles north of it, near Umhlanga Rocks, where the control station was situated. The magnitude of this undertaking may be gathered from the fact that there were seven loops, each consisting of three parallel lines of cable four miles in length, and each separately connected with the control 
station, up to eight miles away. This work, which entailed the accurate laying of nearly 140 miles of cable in unsheltered waters, was completed by the middle of April and the Umhlanga Naval Station - one of the largest and most exposted installations of its kind in the world - went into operation in June 1943. Five H.D.A.S (type 131) had been added by the end of October, but only three of these were effective.

Meanwhile, at Saldanha Bay, the control building was completed at the end of 1942; but no vessel was then available to lay the loops and this was never afterwards effected, partly owing to the greatly reduced importance of the harbour by the middle of 1943, and also because strong defences of other kinds - a controlled minefield and extensive $A / T$ booms - were already being installed there.

The next scheme was to provide indicator loops at Walvis Bay, but changes in the general war situation caused this to be cancelled in September and a complete system of A/S Fixed Defences, planned for Simon's Town, never materialised for the same reason. It was therefore decided, at the end of 1943, that the third (and last) South African loop system would be installed at Port Elizabeth and H.M.S. MEAD was sent there as soon as she had completed certain cable repairs at Durban and Cape Town. The first two loops were laid in January 1944 and the installation, consisting of seven short loops connected to a control station on the end of the Charl Malan Quay, came into full operation on 27th March.

As soon as each loop system was completed it was closely linked up with the other defences, through the local Fortress Command Operation Room. Thus, in the event of a loop-crossing, one or more patrol vessels could be sent forthwith to investigate it; at night or in low visibility (when the crossing might be caused by a surface vessel) it also served as a "standby" to the shore batteries and searchlights. Early in 1943, two non-operational British submarines were allocated to the South Atlantic station; of these, P614 carried out practical tests of the Table Bay $A / S$ defences on 30th March and OTUS did so later at Durban. Crossings by friendly surface vessels, for which a permanent visual watch was kept, also, of course, produced signatures on the recording instruments, so that the watchkeeping personnel soon became quite familiar with these.

Although these elaborate and costly installations probably acted as an excellent deterrent, there was no definitely established instance of an enemy submarine crossing them at any South African port during the war. There were however two distinct unidentified crossing of the Cape Town loops on 13th February and 20th May 1943, when U-boats were known to be in the area. On both occasions patrol vessels obtained brief contacts which were not repeated, possibly owing to the poor A/S conditions prevalent in these waters, caused by the large variations of temperature at different depths. The unidentified signature in May was followed, a few hours later, by a second one which strongly suggested that an enemy submarine had in fact entered, waited on the bottom, and then left without taking offensive action. There were also numerous false alarms, particularly under conditions in which the visual watches were ineffective.

\section{INSTALLATION OF H.D.A.S (TYPE 135).}

While arrangements were being made for the protection of the anchorages, further precautions were taken against the penetration of the inner harbours at Cape Town and Durban by midget submarines by supplementing the existing home-made "Goodlet" loops with H.D.A.S (type 135). At Durban, the pair of 135s installed at the outer end of the entrance channel were working satisfactorily by May 1943, but at Cape Town considerable difficulties were encountered and the two pairs (one for each dock entrance) were not in operation until July. Even then, these H.D.A.s were subject to much interference from dredgers, boom defence wires and high-power electric cables in or near the harbour entrances, so that breakdowns and non-operational periods were frequent. Another weakness, especially troublesome at Cape Town, was that the instruments were 
affected by shoals of fish passing through the entrances and this gave rise to many false alarms. Type 135s were also mounted in the harbour entrances at Port Elizabeth in March 1944 and at East London in September of that year, the latter being the only kind of $A / S$ Fixed Defence installed at the mouth of the Buffalo River.

Owing to accommodation difficulties and to the comparatively small numbers employed, the W.A.N.S. did not take over watchkeeping duties at the Type 135 Stations at Cape Town, Durban and East London which were therefore manned by S.A.N.F. ratings until they closed down in 1945.

\section{D/C THROWERS (HARBOUR DEFENCE).}

The weapons for which the H.D.A.S (type 135) and Goodlet loops were the indicators were depth-charge throwers of the usual sea-going type, mounted so as to drop their charges on or near the position of an unidentified $A / S$ contact or loop-crossing.

Because their installation was simpler than that of the H.D.A.s it was completed first, throwers being mounted at Simonstown and Durban in July 1942 and at the other ports by the end of the year. But there was some delay over the first of these becoming fully operational: the full-size charges provided for $A / S$ vessels were too heavy and too short of range, and it was not until November that 180 pound charges, which had a maximum range of 300 feet, became available. Even then it was feared that they might damage pier foundations and the H.D.A.s, so no live charges were ever fired and practices were carried out with dummy charges of similar weight.

At Simonstown, Port Elizabeth, East London and Cape Town (both basins), where the entrances are sufficiently narrow, one thrower was mounted on each side, and so adequately covered the middle of the channel. The Durban entrance channel, nowhere less than 800 feet wide (including the shallow water on either side), presented more of a problem. As a makeshift, two throwers were first installed side by side on the North pier, other parts of the channel being covered by the motorboat already mentioned. Later, two 100-foot jetties were built opposite each other, at right angles to the North pier and South breakwater and halfway between the inner Goodlet loop and the outer boom. On the platform on the head of each jetty three throwers were mounted and angled fanwise so that an effective six-charge pattern could be dropped. This work was held up for some time by dredging operations and was not completed until the latter part of 1943.

The throwers, like the booms, were manned by artillerymen where their gun positions were conveniently near elsewhere by the S.A. Naval Forces which, at all the ports, was responsible for maintenance, instruction and operational orders.

\section{A/S F.D. PERSONNEL}

The provision of trained officers and men was affected, especially as regards the latter, by the general manning difficulties which prevailed from 1942 onwards and which made it undesirable to employ men on shore who were physically fit for sea service; on the other hand, a fixed defence watchkeeper's duties required alertness, intelligence and a strong sense of responsibility. In the event, the first proviso could not be adhered to and, even then, sufficient men of the right type were hard to find. In April 1943 a particularly adverse report was made on a recent class; not only were there numerous failures to qualify, but several individuals were stated to be of a very low mental standard and others to have subversive tendencies.

Another difficulty was that the number of R.N. specialists was barely sufficient to instal the loop systems and at the same time to train S.A.N.F. personnel. This was got over by building a small training sub-depot on Robben Island, close to the control station of the first indicator loop system to be laid. The instructors were then available, if required, for installation and repair work and the trainees for practical instruction at the station.

All of the A/S F.D. installations were manned and operated as soon as they 
were completed, but only retaining some of the R.N. personnel for rather longer than had been expected: at the end of 1944, 2 officers and 18 ratings were still on loan. In all, 83 S.A.N.F. ratings were trained.

The situation was eased, at the end of 1943, by the employment of W.A.N.S. watchkeepers of which 156 were trained in the next eighteen months. As the Swans took over, most of the men reverted to general service, only sufficient being retained for maintenance duties.

There was less difficulty in finding officers of the right type, including electrical specialists for repair and maintenance work; 54 were trained, including seven for the Royal Navy, and four were later seconded to that service.

\section{THE CONTROLLED MINEFIELD AT SALDANHA.}

The laying of controlled minefields was recommended and given full consideration for several of the South African ports, but in the event only one was laid - at Saldanha Bay, partly because it had been earmarked as a convoy assembly port and also because it was the only land-locked harbour of any size where protection for a good number of ships could be provided by a comparatively small and sheltered minefield. This decision was made in August but there was then considerable delay over the arrival of the mining stores, some of which were wrongly consigned to Durban.

In September 1942 a small party of C/M specialists - three officers and 14 men began to arrive in batches from the United Kingdom. Its senior officer, Lieutenant-Commander J.B. Holmes R.N.R., who was appointed Controlled Mining Officer (South Africa), visited Saldanha and chose the approximate positions of the minefield and control station. In November a detailed plan of the whole system was completed and later approved, its main features being as follows : the northern entrance, 1600 yards wide, between Houtjes Point and Marcus Island, was protected by three mine-loops and the southern entrance, 2600 yards wide, between Marcus Island and Eland Point, by five mine-loops. There were 12 mines in each loop and, as the loops were 600 yards long, they overlapped each other considerably. They were numbered from one to eight, starting at the northern end of the line. About a mile to seaward of them were three guard-loops, each 1.3 miles long and also overlapping. The tailcables of all eleven loops were led into North Bay (immediately to the west of Houtjes Point), on the east side of which the control station was situated.

Early in January 1943 the C/M Base ship of the Eastern Fleet, H.M.S. MANCHESTER CITY, and a C/M layer, H.M.S. SPINDRIFT, which had been waiting at Cape Town for four months, arrived at Saldanha. The laying of the three guard-loops was completed by 4 th February and all the mine-loops and tail cables were in position by the end of March.

In the meantime the control station and accommodation for mining stores and personnel had been built, so that the system became operative in the middle of April. No. 3 Loop, however, was already out of action owing to the rocky bottom and in the course of the next three months No 4 and 5 also became defective. It was therefore arranged that SPINDRIFT should remain at Saldanha for cable-maintenance instead of another vessel which the Admiralty had intended to send out later. She was taken over by the S.A. Naval Forces on 5th July 1943 and her first major operation as a South African ship was the successful recovery of No. 3 and No. 4 mine-loops which was completed in August. This included some particularly good work by the S.A.N.F. diving party of whom Lieutenant J.H. Johanssen (M.B.E.) and Chief Petty Officer A.V. Whitehead (B.E.M.) later received these decorations for this and other diving operations.

As Saldanha had by this time ceased to be used by merchant shipping, the Senior C/M officer suggested that the re-siting of these mines might be deferred, in order to preserve them pending the anchorage again coming into use. This however, was not approved, and SPINDRIFT was fully employed on repairs and replacements from that time 


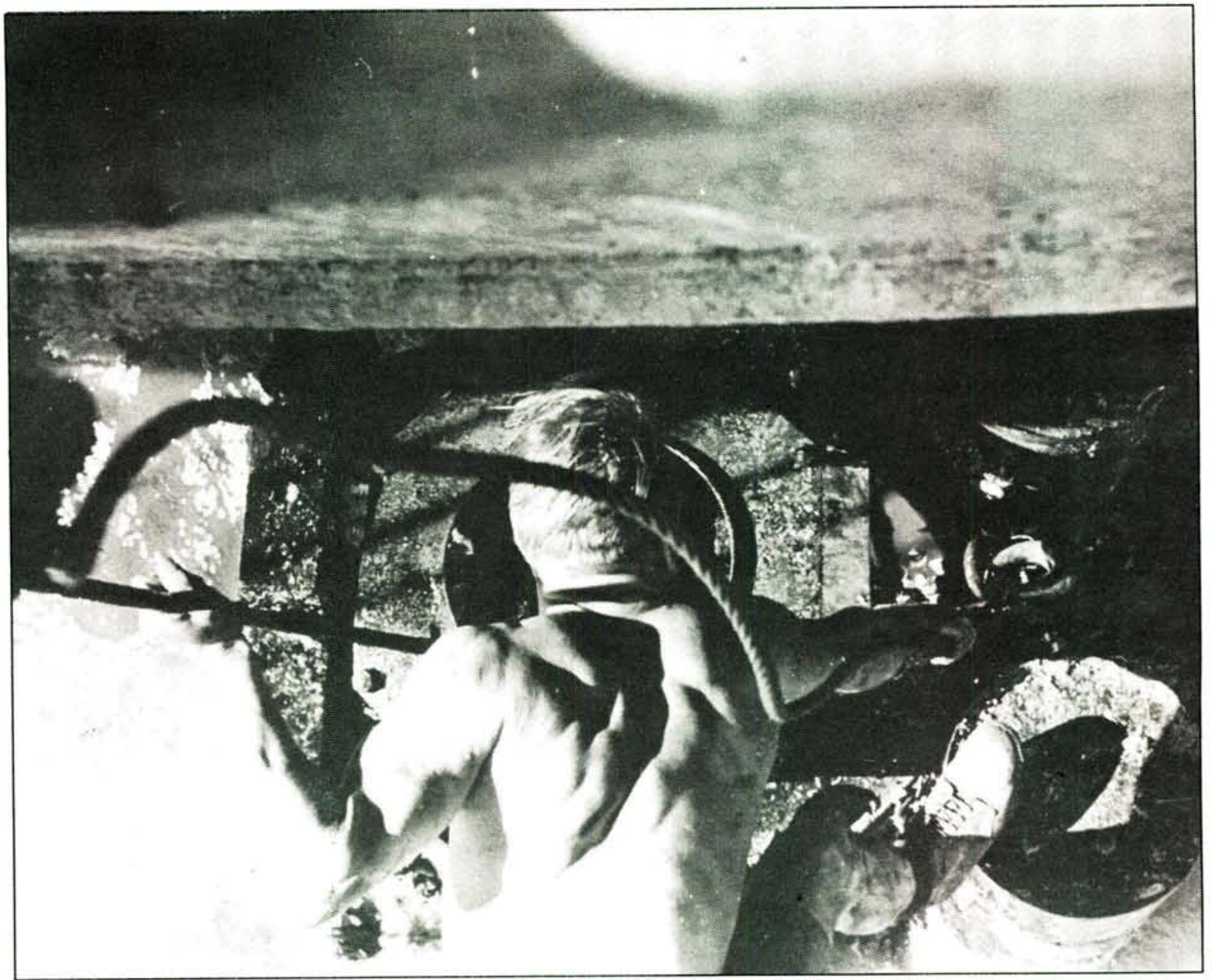

Recovering a defective mine at Saldanha.

onwards, every mine-loop being renewed at least once during the next 12 months. As a result of practical experience, considerable changes were made in the number and positions of the mine-loops which spanned the southern entrance: for about a year there were only three (numbered 4,5 and 6 ) in place of the original five. A fourth was then added, so that there were altogether seven mine-loops by 1945.

\section{PROVISION OF C/M PERSONNEL.}

Soon after the arrival of LieutenantCommander Holmes in September 1942 , arrangements were made for the C/M training of S.A.N.F. personnel who would eventually take over the station. Four officers and 15 ratings were required as watchkeepers in the control station and at least one officer and 10 wiremen for repair and assembly work in the $\mathrm{C} / \mathrm{M}$ base. A commanding officer and other specialists would also be needed for the $\mathrm{C} / \mathrm{M}$ layer when taken over from the Royal Navy, so that the total number to be trained was at least 40. After a month of theoretical instruction in the Cape Town Training Base in November 1942, the first class four officers and twelve ratings - were sent to Saldanha to gain practical experience and were there while the loops were being laid. As a result of a request by the Admiralty for eight officers and 40 ratings for $\mathrm{C} / \mathrm{M}$ duties outside South Africa, subsequent training classes also included S.A.N.F. Seconded Personnel specially recruited for the purpose and this quota was provided in due course.

By the beginning of May 1943, all except two officers and one rating provided by the Royal Navy had been replaced; of these, Lieutenant-Commander Holmes remained as the senior C/M officer until November 1944. By the end of August 1943, 18 officers and 50 ratings had been trained in laying, watch-keeping and maintenance work. In the latter part of that year the C/M 
base was completed in all respects and it was then possible to assemble complete mine-loops as spares, the work being carried out by S.A.N.F. wiremen of which nine had been trained by then. In April 1944 the ratings employed as control watchkeepers were replaced by female personnel (W.A.N.S.).

\section{OPERATIONAL FIRING OF TWO MINE-LOOPS.}

The only occurrence of operational interest at Saldanha took place on the night of lst June 1944. As is recorded in the chapter dealing with the Ger- lights were exposed over the mined area but they revealed nothing. It was therefore considered that a submarine might be present, probably having first crossed guardloop No.1 which was unreliable, being subject to severe perturbations. Searchlights were switched off at 2225 and it was decided to regard any further signatures as hostile. AT $2314 \mathrm{M} 6$ registered a swing and was fired, though a shade on the late side; 20 seconds later, M5 also registered and was fired immediately. If one submarine was the cause of both signatures, this could be explained by her having crossed them obliquely, or at the overlap. The search-

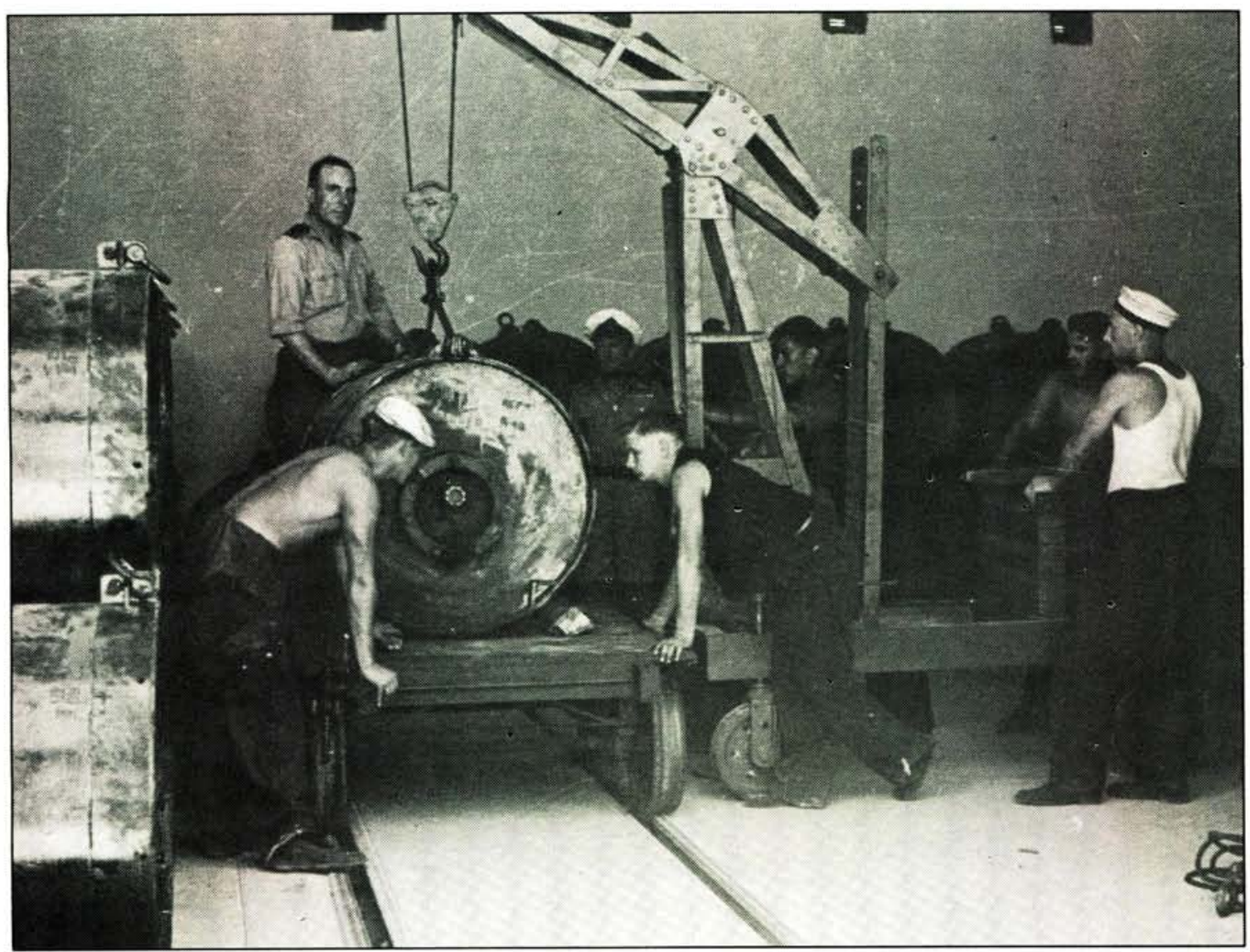

Loading a mine prior to moving it to the assembly area at Saldanha.

man Submarine Offensive, an intercepting operation off Cape Columbine was then in progress as a result of a Uboat having been seen off Walvis Bay four days earlier.

At 2158 , mine-loop No $5(\mathrm{M} 5)$ registered a decided "swing"; no action was taken as the guardloops had recorded no signature and it was thought possible that an out-going local vessel might have failed to report here intended movements. AT 2215 search- lights were exposed even before the last explosions had subsided but no sign of wreckage was seen. The examination vessel then got under way and searched the area without result. During the next fortnight the bottom was carefully searched by echo-sounding and groundsweeping but nothing was discovered. A diver was sent down to examine one position but his report was negative, except that he had "nearly fallen into a hole about 30 feet deep". As the average depth of water was about 100 feet, it was 


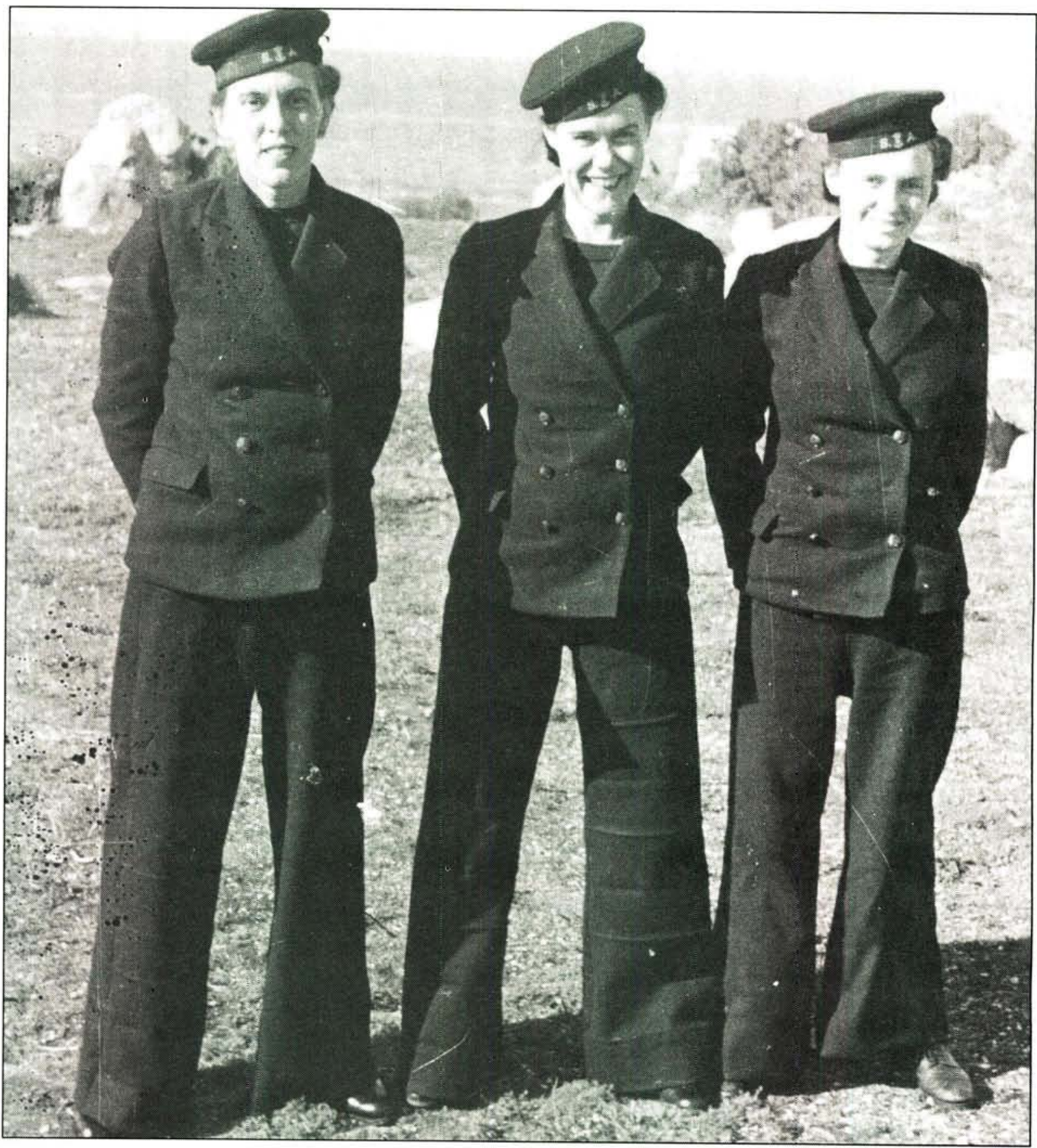

The SWAN watchkeepers who fired the controlled minefield at Saldanha in anger: $F$. Klonus, S. Labuschagne and E. MacFarlane.

not considered justifiable to make a wider search by diving. This ended the matter, for nothing since has come to light as to this suspected attempt by the enemy to enter Saldanha.

In September 1944, six slightly defective mines were assembled as a loop which was then laid, clear of the main minefield, and fired for experimental and instructional purposes.

Early in 1945 it was deemed unneces- sary to keep the system in operation and it ceased to be manned on loth March. As their recovery was likely to be lengthy and somewhat dangerous, the mines were exploded on 6th April. First, the four loops which then crossed the southern entrance were fired at three-minute intervals, followed by the three northern loops half-an-hour later. Photographs revealed that three mines (out of 84 ) had failed to explode. These were found by divers, buoyed, and later destroyed by depth-charges. 


\section{THE DEVELOPMENT OF SALDANHA BAY}

Saldanha Bay, 67 miles north-northwest of Cape Town and the finest natural harbour in the Union of South Africa, never became a seaport because of the lack of fresh water prior to 1942. The nearest river is more than 20 miles away and the only local source was a well at Oostewal, three miles up Langebaan Lagoon and approachable only by shallow-draught vessels. Thus the only amenities at Hoedjes Bay, the northern and most sheltered side of the harbour, were a railway station, two or three small boat jetties and the village of Saldanha which subsisted on rain-water and on small quantities purchased by the bucketful from the railway tank. Five miles away, on the southern side of the entrance, were the buildings and jetty of Donkergat whaling station which, until it went out of use in 1937, had obtained its water from Oostewal.

For many years Saldanha Bay had been included in the Admiralty war plan as a possible relief anchorage and in March 1939 it was one of the socalled defended ports at which the usual shipping control services (with a contraband control service at Saldanha only) would be established by the Defence Department when required.

On the declaration of war no action was taken concerning Saldanha; the general conditions did not warrant it and in any case, while the RNVR (SA) remained unmobilised, there were barely enough personnel to man the naval services at other ports. Adm Hallifax, however, reminded Defence Headquarters at the end of October 1939 that the harbour might be required as a convoy assembly port at short notice. (Although the SDF did not begin to function until three months later, its Director was already acting as the link between the Defence Department and the RN.) He was then informed that the necessary arrange- ments could be made within a month; but the authorities apparently were not quite sure about this, for early in 1940 they inquired as to the possibility of maintaining an Examination Service there.

After discussing the matter with the SNO, Simon's Town, Adm Hallifax reported in March that it would be impracticable to do so in all weathers owing to the absence of a separate and sufficiently sheltered anchorage where ships could await examination. In fine weather, ships could be dealt with on arrival in a special area outside the harbour, but when they could not be boarded there, they would have to be treated as suspect and ordered to proceed to Cape Town for examination. Even this would require all the components of a complete Examination Service, namely a Port War Signal Station, an examination vessel and gun defences to cover ships before and during examination. Escorted convoys and single ships flying the special signal would, of course, require recognition only. No action was taken for the time being, but the provision of an examination battery was considered and in August the Admiralty stated that two 6inch (Mark VII) guns could be provided.

The urgency of developing Saldanha as a defended port was lulled on 12 September 1940 when SNO Simon's Town stated that there was no immediate prospect of a convoy system being instituted in the South Atlantic; he hoped, however, that preparations for this would continue. In October, Adm Hallifax gave an appreciation of the additional SDF commitments which would be involved: he stated that out of the total number of 52 vessels then authorised, he would eventually be able to provide a small local flotilla of minesweepers and A/S vessels for Saldanha, but that the existing establishment of personnel made no allow- 
ance for manning the other naval services which would be required.

Meanwhile, from 1939 to 1942, the harbour was available for any ships friendly or otherwise - which cared to use it, without any regular check being

\section{THE WATER SUPPLY}

It was in October 1940 that the provisz ion of sufficient fresh water appears to have been seriously considered for the first time. As well as supplies of drinking and boiler water for the SDF ships and

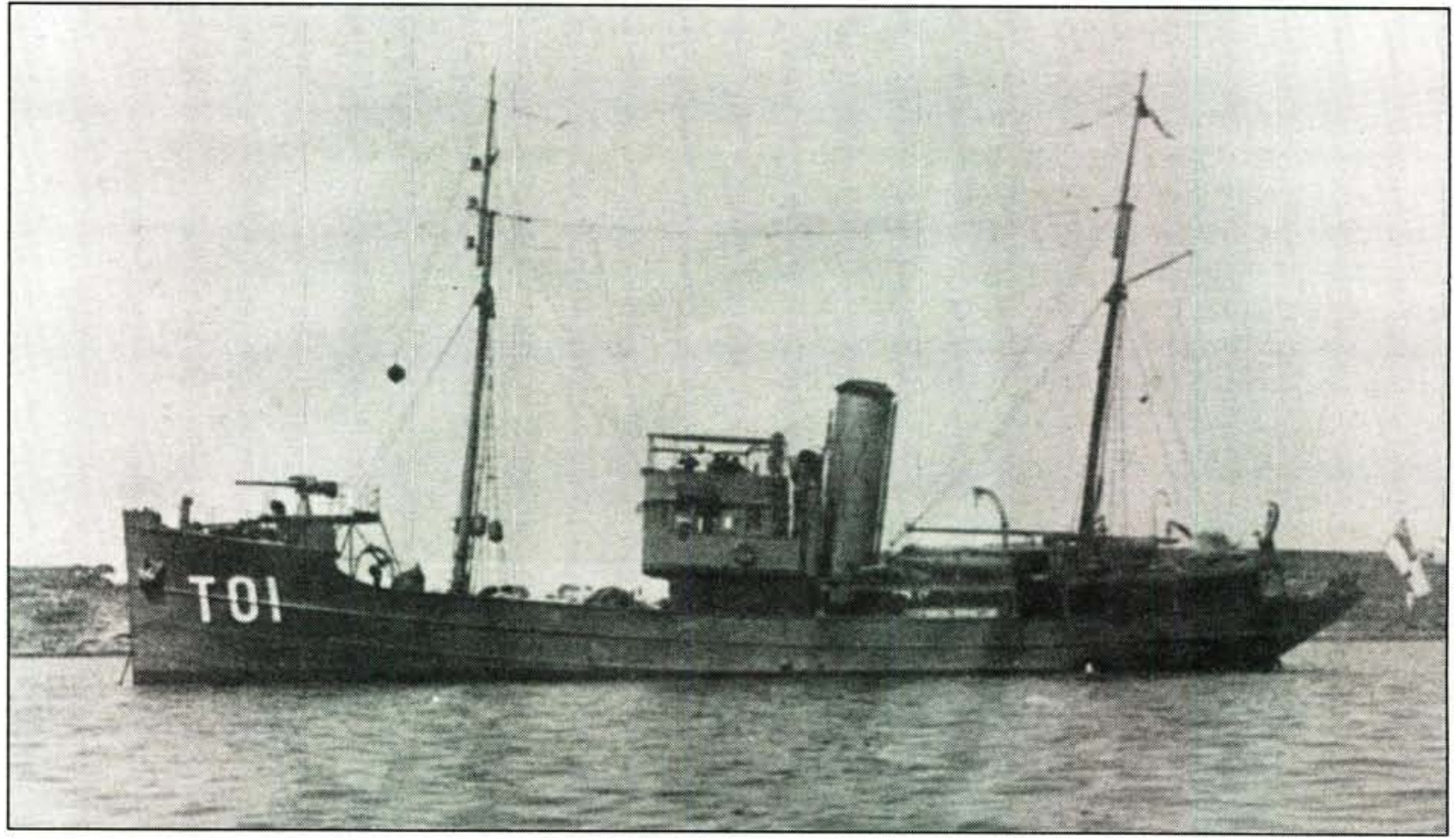

HMSAS AFRICANA.

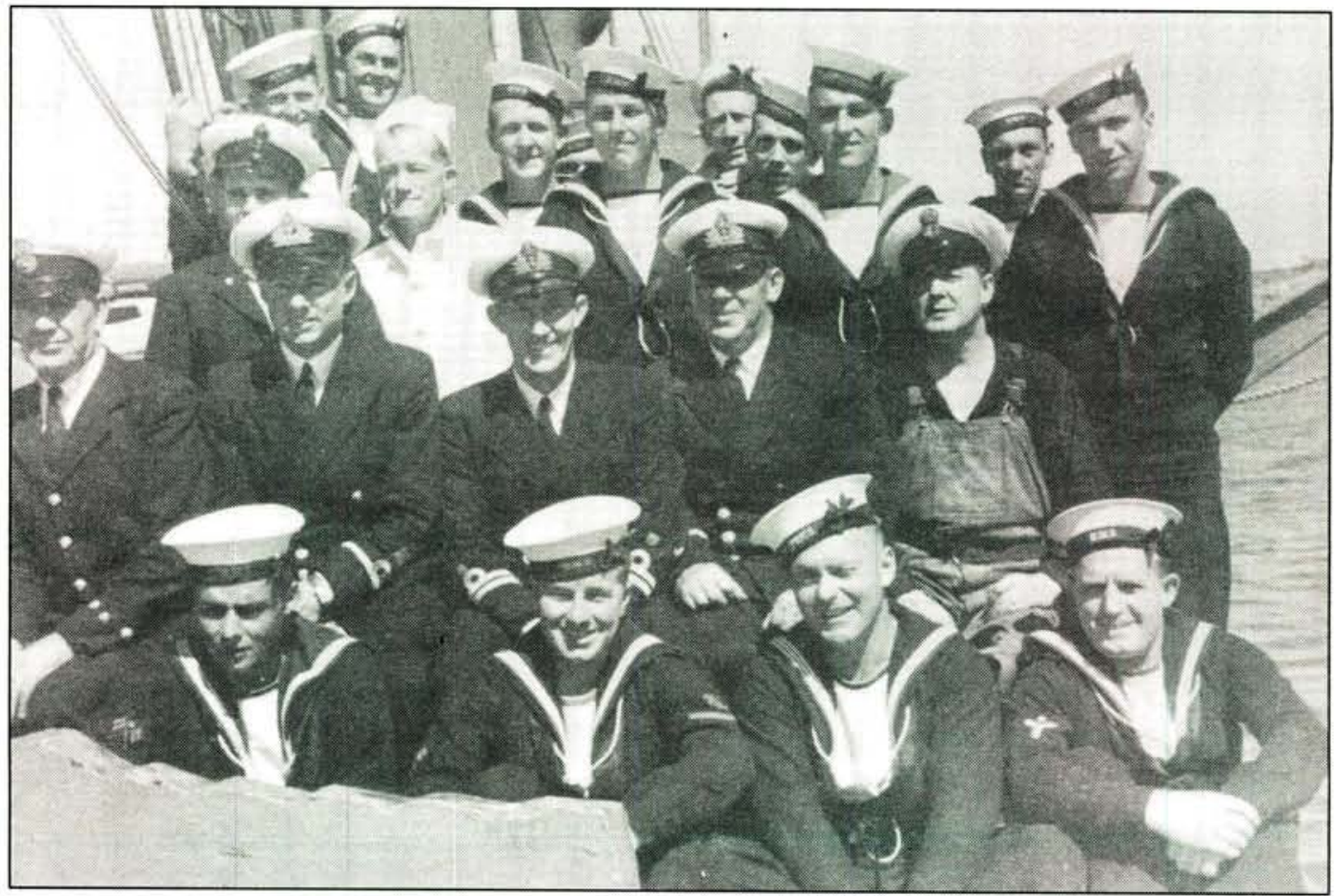

Ship's Company of HMSAS AFRICANA.

kept of their identities or movements. In April 1941 HMSAS AFRICANA, which happened to be at Saldanha for a week with an officers' training class, boarded two tankers in the anchorage and examined their papers. about 24 shore-based SDF personnel, allowance had to be made for a RN establishment of up to 100 officers and men to deal with the convoys and other local matters coming under the Admiralty. Adm Hallifax estimated 
these requirements at 155 tons per week, which made no provision for military personnel, port authorities or other civilians.

From the middle of 1941, when the preliminary work began on roads and gun emplacements, a very hand-tomouth supply was maintained by bringing fresh water from Oostewal in small local craft and by using brackish water from a well near Hoedjes Bay. Other schemes were then discussed and in November 1941 the small waterboat IRONIC was sent to Saldanha as a stop-gap. Early in 1942, when extensive defences were decided upon and the provision of an adequate water-supply and other amenities became urgent, several conferences were held. It then became clear that additional water-boats were not available and that, even if they were, the Oostewal well could not be relied upon for the greatly increased requirements. It was therefore decided to construct a pipe-line, 27 miles long and capable of providing 1 million gallons a day, running from the nearest non-tidal point on the Berg River to Hoedjes Bay. This big undertaking began in July and was completed at the end of the year, most of the work being done by military engineers.

\section{SALDANHA BECOMES A DEFENDED PORT}

Early in 1942 also, largely owing to the newly added menace from Japan, the most urgent items of the Defences were hurriedly taken in hand: wooden buildings, to house the Port War Signal Station and Wireless Station, were erected on North Bay Hill; a battery of two 6-inch guns on mobile (Mark XIX) mountings was installed on Baviaanberg, on the north side of the entrance; and hutments and a commandeered house were prepared for the necessary personnel, including that of the Examination Service. In April, the provision of accommodation required by the Royal Navy, for upwards of 150 officers and men, was gone into and soon afterwards the SAR \& $H$ Administration also stated its requirements. In the event, the latter were required and provided in skeleton form only.
By the beginning of June 1942 the volume of shipping arriving in Table Bay had so greatly increased that it was resolved to use Saldanha immediately as a relief anchorage, though it was by no means ready as yet for use as a convoy assembly port. The existing defences were manned, the examination vessel WILLIAM HOLLAND arrived on 21 June and from that date the procedure for a defended port was carried out in full. Protection to seaward was provided by one A/S vessel which patrolled off the port and by the sweeping of the newly authorised Searched Channels, which had begun in May. On 11 september, HMS GUARDIAN, special net-layer, arrived and spent a month at Saldanha; she laid a light $A / S$ indicator net across the entrance, west of Marcus Island, but it was soon damaged by a ship and what remained of it was lifted.

On 11 July, the SAR \& H Administration took over the internal control of the port and provided a Marine Assistant, who acted as boarding officer and pilot. Merchant ships had already begun to arrive in small numbers and from September to January the arrivals averaged about 40 per month. In February and March 1943 the monthly arrivals were over 70, in April and May about 35 , but after that the harbour went almost completely out of use except for vessels which had to be laid up for long periods. Up to the end of the war, there were 457 arrivals by merchant ships of which the two largest were CAPE TOWN CASTLE and DOMINION MONARCH, each of about 27000 gross tonnage. The greatest number of merchant ships present at any one time was 24 , but double that number could have been accommodated, all of them in the calm water under the lee of Hoedjes Point. In the southern and less sheltered part of the harbour, anchor berths could have been provided for an additional 100 ships of average size.

In October and December of 1942, two 12-pounder batteries of two guns each, near Hoedjes Point and Eland Point, were installed so as to cover the narrowest part of the entrance and the boom when completed, from north and south. The main gun defences 
consisted of two batteries, each of two 6 -inch guns, at the northern side of the entrance. The Noord Battery, on North Bay Hill, was completed in January 1943 and the Baviaans Battery (which replaced the original examination battery) in March 1943. At the end of October 1942, three Catalina aircraft arrived at Saldanha to assist in countering the first attacks by U-boats and more arrived later; as a result, a flyingboat base was established at the old whaling station at Donkergat.

\section{PORT INSTALLATIONS}

Saldanha never became a convoy assembly port, but preparations for this continued for the next year or more. At the end of 1942 work began on the new jetty, which eventually was to have a depth alongside its outer end of 22 feet and dolphin extensions where deep-draught ships could be supplied with water and oil-fuel. This progressed so slowly that the cut-down hulk of the ex-German ship PRASIDANT - a relic of the 1914-18 war, conveniently beached nearby - was converted into a temporary jetty: on its completion in May 1943, a hydrant was installed there and for the first time water from the Berg River pipeline became available for shipping, though a water barge was still required for supplying deep-draught vessels, the PRASIDANT jetty continued to be the main landing- place until March 1944 when SANF vessels began to use the new jetty which was used later for landing the dismantled boom; but it was not completed with its extension dolphins until May 1945. From December 1942, a steam collier was permanently stationed in the harbour. In May 1943 she was replaced by a hulk (the ex-sailing ship COMMODORE) which was towed to Cape Town when she required refilling. This arrangement continued until railway lines were installed on the new jetty in 1945. In June 1944 the Shell Company completed the erection of seven oil tanks with a capacity of 9500 tons, with the necessary machinery and pipes laid onto the jetty.

\section{SANF DETACHMENT AND TRAINING CENTRE ESTABLISHED}

During 1943 an administrative block and a barracks with accommodation for 250 men was completed for the Royal Navy. They were never fully used, but a Naval Liaison Officer and staff were stationed there until 30 April 1944. Then, as at Walvis Bay, the senior officer of the SA Naval Forces took over the few RN duties which remained. After some discussion as to the use which could be made of the Admiralty buildings, they were rented by the Defence Department and the administrative block became the local headquarters and officers' block of the SANF. The barracks also came into use soon afterwards.

Until I December 1944, the SANF at Saldanha Bay were administered from Cape Town, but on that date they became a separate detachment and remained so until the end of 1945 . 

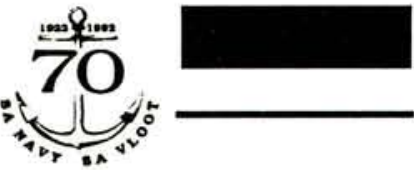

\section{BOOM DEFENCES : PRE-WAR ARRANGEMENTS}

The provision of booms was the only kind of naval fixed defence considered and partially prepared for, before the war. As far back as 1921, when the South African Government took over all the military defences, it also accepted responsibility for this form of harbour protection, including that at Simon's Town

In July 1935 a meeting of the Net and Boom Defence Committee was held at Cape Town and certain recommendations were made, including the provision of some of the gear which could be obtained in South Africa and the purchase from the Admiralty of sufficient anti-torpedo nets to span the two harbour entrances at Cape Town. For these, £4 000 was paid during the Financial Year 1937-38, but in November 1938 the nets intended for the Victoria Basin entrance were rendered unserviceable by a fire in the $\mathrm{New}$ Quay shed.

In March 1938 the Staff Officer SANS drew the attention of the Defence Department to the fact that no one in particular was responsible for the isntallation of anti-torpedo booms; he also pointed out that, although the King's Harbour Master, Simon's Town had done a Boom Defence course and his advice was then available, he would be unable to assist in time of war.

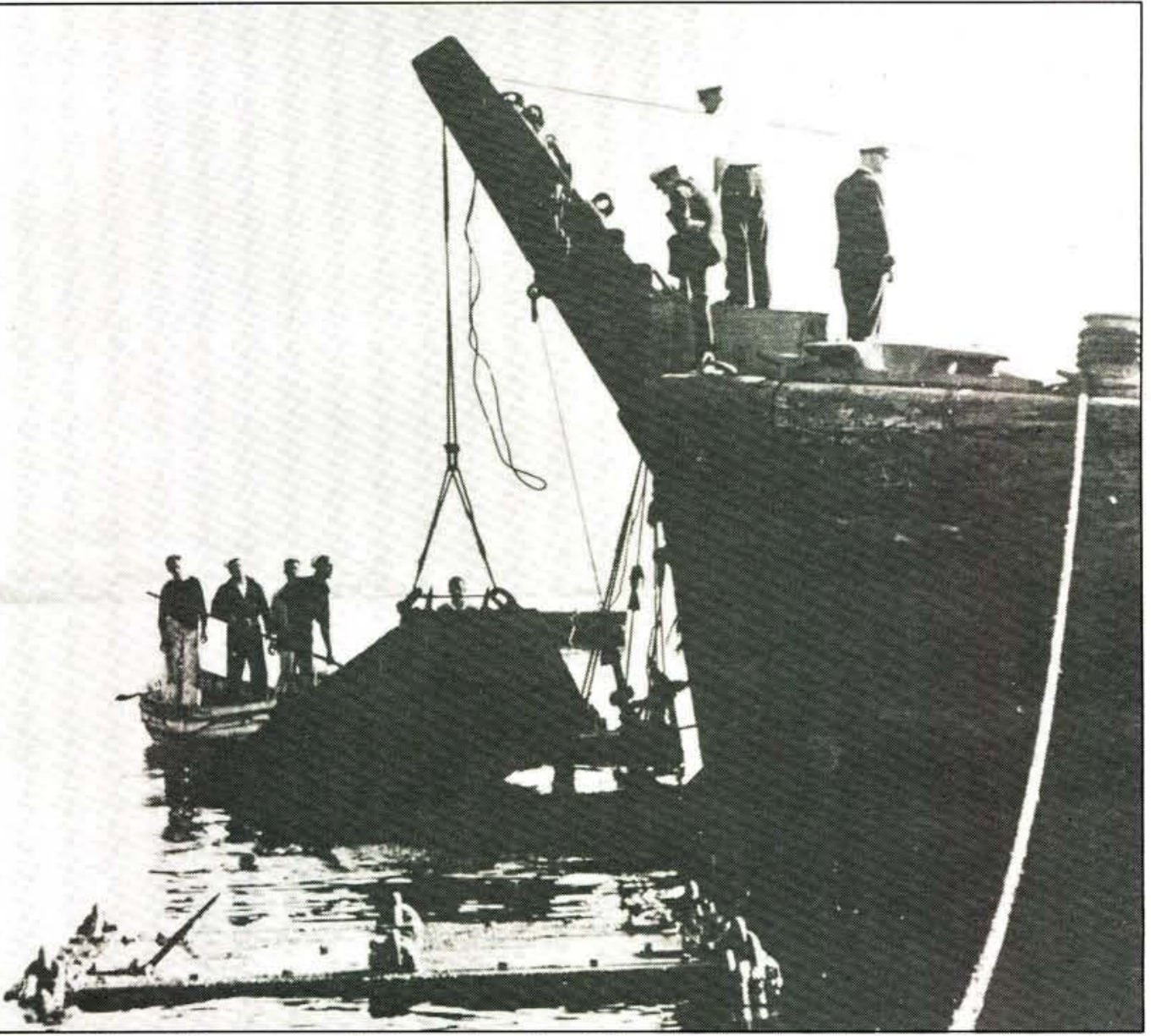

The mooring lighter lifting an anti-boat baulk at the harbour entrance in Simon's Town. 
It was therefore decided that the $S A R$ \& $H$ Administration should be responsible for the assembly and maintenance of the boom gear in time of peace - and for its erection when required. It was also arranged that the Assistant Port Captain, Cape Town who was proceeding to the United Kingdom on leave, should receive the necessary training at the Boom Defence School at Rosyth. He completed the course in November 1938 and, as a result of further representations by the naval authorities, made a tour of the ports in May 1939 and planned a boom defence system for each. His suggestions were accepted by the Defence Department, but it was decided that for the time being, only the two entrances at Cape Town would be protected by $A / B A / T$ booms, and that the booms at Durban, Port Elizabeth and East London would be of the $A / B$ type only. (An A/B (anti-boat) boom gave surface protection only. The baulks and the jackstays linking them, were fitted with spikes to prevent their being "jumped" by shallow-draught torpedo craft. The baulks provided sufficient buoyancy for $A / T$ (anti-torpedo) nets to be suspended from the boom, which was then described as "A/B A/T".) The Defence estimates for 1939-40 made provision for the additional gear required, but as some of it was not then available in South Africa, there was considerable delay over its assembly.

\section{ADMIRALTY RECOMMENDATIONS AND GENERAL POLICY REGARDING BOOM DEFENCES}

The provision of boom defences after the outbreak of war, like many other items in the South African war effort, was influenced firstly by the varying likelihood of attacks on the ports and secondly by the availability of materials. The nature of the booms at the individual ports, described later and the priority given to their installation must therefore be considered in relation to the following phases:

Outbreak of War. No facilities existed for producing boom gear on a large scale or for making anti-torpedo nets, of which only a small stock was in the country. The most likely form of attack was by small surface torpedo-craft (launched from raiders) and therefore A/B booms could be accepted except where shipping lying inside the booms was exposed to torpedoes discharged from outside, either by surface craft or ocean-going submarines. Where this had to be guarded against, the boom had to be $A / T$ also and, even then, a single line of nets was considered to provide only $60 \%$ protection. This had been pointed out by the Admiralty some time earlier, but the cost of providing and maintaining materials for double-boom systems at all South African ports in peace time was not considered to be justified. On the outbreak of war, however, the Defence Department ordered sufficient $A / T$ nets to double those at Cape Town.

May and June 1940 - Serious Allied Reverses. Although the RN authorities pressed for the doubling of the Cape Town booms on account of the probability of war with Italy, Adm Hallifax (Director, SDF) disagreed. He argued that with ships continuously lying outside Table Bay docks (as a result of the increased traffic on the Cape route) enemy attacks, if made, would now be directed against these easier targets. On the other hand, he obtained approval for the installation of $A / B$ booms at Durban and East London. It is probable that his views were influenced by the fact that $A / T$ nets deteriorate rapidly while submerged and that those which had recently arrived at Cape Town might soon be required to replace the single nets already in use. It will be seen that, in the event, the East London boom was fitted with $A / T$ nets for a special reason.

Early in 1942 - The Threat from the Far East. Even before the penetration of the Japanese into the Indian Ocean and their subsequent attacks on shipping off East Africa, their use of seaborne aircraft and midget submarines against Pearl Harbour caused the Admiralty to make urgent recommendations, particularly for the protection of the vulnerable pumping machinery and caissons of the graving docks at Durban and Simon's Town. The duplication of the harbour entrance booms was again asked for, with priority for those two ports and a third boom (and anti-aircraft defences 
When they could be provided) was recommended for the immediate protection of each dry-dock entrance against air-borne torpedoes. It was pointed out that the estimated $60 \%$ protection of one line of nets had not taken into account the lifting or cutting devices with which midget submarines were believed to be fitted. As most of the gear still had to come from Great Britain and it was all absorbed in complying with these more urgent requirements, the second lines of nets at Cape Town once more did not materialise - nor did they ever do so. It was during this period that harbour entrance booms were first closed nightly as a matter of routine.

1943 and Later. Although the Japanese threat receded almost as quickly as it had arisen and the general situation continued to improve in all other theatres, nothing was left to chance. The local manufacture of $A / T$ nets and better facilities for refitting other boom gear made it possible to maintain all the installations at full efficiency and they were worked regularly until the end of the war against Germany.

Before their defeat in 1943 - indeed, as far back as 1918 - the Italians had specialised in the development of under-water weapons, other than submarines, for attacks on harbours. They had scored several notable successes with these and it was highly probable that the Germans and Japanese were already improving upon the Italian inventions. Among the counter-measures installed at Gibraltar and elsewhere was the catenary net, a light wide-meshed net which was sufficient to stop these "human torpedoes" and other low-powered contrivances and which could be opened or closed (on the suspension principle) in a matter of seconds, compared with the minimum of twenty minutes required for the operation of the average gate boom. Early in 1943 it was suggested that catenary nets should be installed at Cape Town and Durban, but eventually only Durban harbour was so protected, as is described in greater detail under "Boom Defences at Durban".

The Cape Town Booms. On the outbreak of war the installation of the Cape Town system was immediately put in hand: by mid-October 1939 , three electric capstans had been mounted and the two booms had been rigged and operated. At first. only the entrance to the New Basin was protected by $A / T$ nets, but additional nets arrived in October and the Victoria Basin boom, which was 250 feet long, was so fitted by the end of the year. The estimated total cost of the two booms was $£ 3080$ and this figure was approximately adhered to. Early in 1940 the widening of the New Basin entrance, as designed, was taken in hand and in March the boom was lengthened from 450 to 750 feet. But as the work on the entrance progressed, it was found that the basin was over-exposed to sea and swell, so the mole was reconstructed, reducing the entrance to its present width of 400 feet; the boom was therefore shortened again and when the pier-head of the mole was completed, a petroldriven winch was mounted there to replace the indirect haul from the other side.

Although the Cape Town booms were not opened and closed regularly at this time, the question soon arose as to who should do so when required. Just before the SDF took over local naval defence from the RN in January 1940 , Adm Hallifax arranged with the Port Authorities that SAR \& $H$ employees volunteers, who would be paid a retainer - should be trained and be available at short notice. A year later, by which time a small docks battery had been built between the two entrances, it was suggested that the military personnel employed there should assist with the working of the booms. This was agreed to after some discussion and the final arrangement, which came into force on 1 June 1941, was that the SDF would man the western side of the Victoria Basin entrance, the soldiers the inner sides of the two entrances and that the duty SAR \& $H$ berthing party, using their launch, would attend to the eastern side of the New Basin entrance (shortly afterwards, this latter duty was taken over by the SDF). These two booms and those installed at the other ports, were of the gate type and were secured to buoys when open; they took about half-an-hour to open or close under average conditions of tide and wind. 
The Simon's Town Boom. At Simon's Town, a complete A/B A/T boom had been in readiness for protecting the entrance to the basin for some years before the war. The floating part of it, which consisted of four timber rafts, was tested annually; but the nets were not slung under the boom because even one immersion would have caused their rapid deterioration. When the nets were fitted at the outbreak of war, it was found that the rafts, which were more than twenty years old, no longer had sufficient buoyancy. After some discussion, chiefly concerned with the cost involved, a new boom similar to those at Cape Town was constructed; it was installed in May 1940 by the Director of Fortifications in consultation with the SNO. All repairs, including the supply of new $A / T$ nets about once $a$ year, were at the cost of the South African Government which also provided a second $A / T$ boom for the entrance to the basin in September 1942 and a third, to protect the graving dock caisson, in October 1942.

Boom Defences at Durban. At the outbreak of war, as a result of Italy remaining neutral, the boom defence schemes for the commercial ports other than Cape Town were held up and a conference, at which the Director General of Operations presided, was convened to consider more economical means of providing protection.

These discussions, which had no concrete results, ceased abruptly in June 1940: on 21 June, instructions were issued for the construction of a boom across the entrance channel at Durban. There, where the sides of the long channel are shelving, the work was much less simple than at Cape Town where the ends of the nets fitted snugly against the vertical pierheads. At that time, however, a number of large concrete caissons were being constructed in the old floating dock (condemned for the use of shipping) for use as the foundations of the new "T" jetty. Two of these caissons, measuring roughly 50 by 25 feet and 40 feet high, were therefor towed to a position near the seaward end of the old Repair Quay and bedded down opposite each other, 425 feet apart, on either side of the deep-water portion of the channel. The gateboom, then of the surface type only, hinged on the southern caisson and was moored to a wooden dolphin further downstream when in the open position; power was provided from a capstan on the southern shore and a large electric winch mounted in the northern caisson itself; fixed $A / B$ extensions covered the shallow water between the caissons and the north and south shores.

Although one of the caisons was wrongly placed and had to be pumped out and relaid, this work was completed by 14 July at a total cost of $\$ 11353$. Like those at Cape Town, the Durban boom was at this time worked only occasionally, as an exercise and the only way of reaching two of the operational points - the northern caisson and the wooden dolphin - was by boat. This was not rectified until August 1941 when these points were connected with the shore by two cat-walks.

Additional Booms at Durban. In March 1942, considerable additions to the Durban boom defences were authorised and in April a large consignment of nets and other gear was shipped there from Cape Town. First, the existing boom, including the fixed extensions, was converted to $A / T$ by the addition of nets; it was completed by the end of May and from then onwards was closed at sunset and opened at dawn. As they were well placed for doing so - at the docks battery on the north side and the Bluff on the south side - artillery personnel were employed for this and also for operating the second entrance-channel boom, added later.

As soon as this work was completed, an $A / T$ boom was assembled and launched in the Graving Dock Basin in June. Its northern end was permanently secured to the north wall of the basin and it was bunched on that side when open; when closed, which was its normal position, its movable end was hauled to a mooring buoy near the floating dock on the southern side. In this position the boom lay at an average distance of about 40 feet from the dock caisson with a sufficient overlap on each side. It was operated by naval personnel from the SDF head-quarters nearby.

The third and largest item was the provision of a second $A / B$ A/T boom 
boom by then required almost complete renewal. Additional gear was collected with some difficulty, some of it being shipped from Cape Town in the recently commissioned salvage vessel GAMTOOS, then on her way to the Middle East. The renovated boom was installed on 26 November 1942.

The provision of an $A / B$ boom for Port Elizabeth was first considered at the same time as those for Durban and East London, but no action was taken: the entrance there is about 1350 feet wide and in July 1940 the materials were not available, even for a surface boom.

The matter was revived among the other recommendations for increased protection early in 1942, by which time portion of the boom, 750 feet long, was completed first and was in position by 16 February; the 600 -foot gate, which hinged on the Charl Malan pierhead, was launched on $26 \mathrm{March}$ and after successful trials, the boom came into routine operation on 20 April 1943. It was worked by military personnel.

\section{Saldanha Bay Boom Defences}

In the account of the installation of the controlled minefield at Saldanha, reference already has been made to the expected importance, which never fully materialised, of that harbour. The first form of defence upon which a clear decision was reached (in April 1942) was the provision of an antitorpedo boom. As the entrance at its

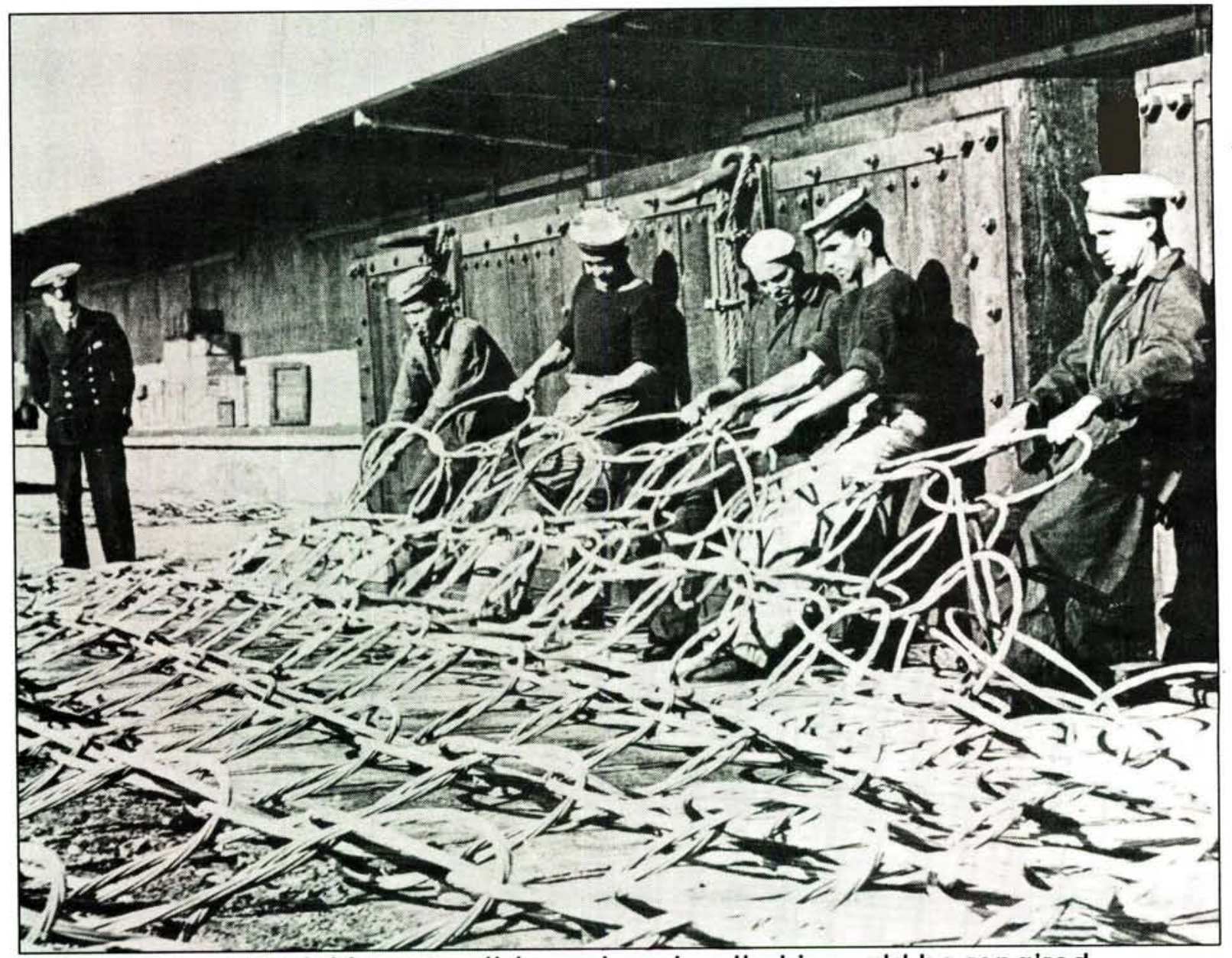

Ratings stretching an anti-torpedo net so that is could be repaired.

it had become apparent that all booms should be fitted with $A / T$ nets. Defence Headquarters eventually agreed to this on condition that the Admiralty would provide the materials at its own expense, which it did and the first consignment of gear reached Port Elizabeth early in December. The fixed narrowest point has a width of twoand-a-quarter nautical miles and is exposed to considerable sea and swell, the task was obviously beyond the scope of local resources and the Admiralty agreed to provide the materials (with the excepion of the mooring columns - concrete clumps weighing 5 
tons or more - of which the SAR \& $H$ made 295) and lay the boom.

HMS BARCROSS, boom-layer, arrived at Cape Town on 14 August. HMS FERNMOOR (a merchant ship of about 7000 tons converted to boom carrying vessel), arrived on 18 September and the laying of the boom commenced on 28 September. It was soon realised that the work would be very heavy and the captain of BARCROSS estimated that it would take a minimum of 216 working days if only one layer were employed. A second boom-layer, HMS BARBRAKE, arrived at Saldanha on 14 January 1943. In accordance with the accepted policy that the SA Naval Forces would take over all naval fixed defences together with the vessels required for their maintenance, BARCROSS then proceeded to Simon's the date of completion being 29 May 1943.

As originally designed, the boom was to have had a gate, but it was soon realised that the two additional vessels required for this would not be available; it was therefore decided to substitute a permanent opening, the sides of which would be staggered so that a torpedo, fired from seaward, could not pass through it. "A" baffle, which closed the northern entrance between Hoedjes Point and Marcus Island, a distance of 5000 feet, was laid first; then came " $B$ " baffle, which ran from Marcus Island to a point 5400 feet to the south-west; and lastly, "C" baffle, extending from Boat Rock on the southern side to a point 5200 feet in a northerly direction. This placed the southern end of " $B$ " baffle 400 feet

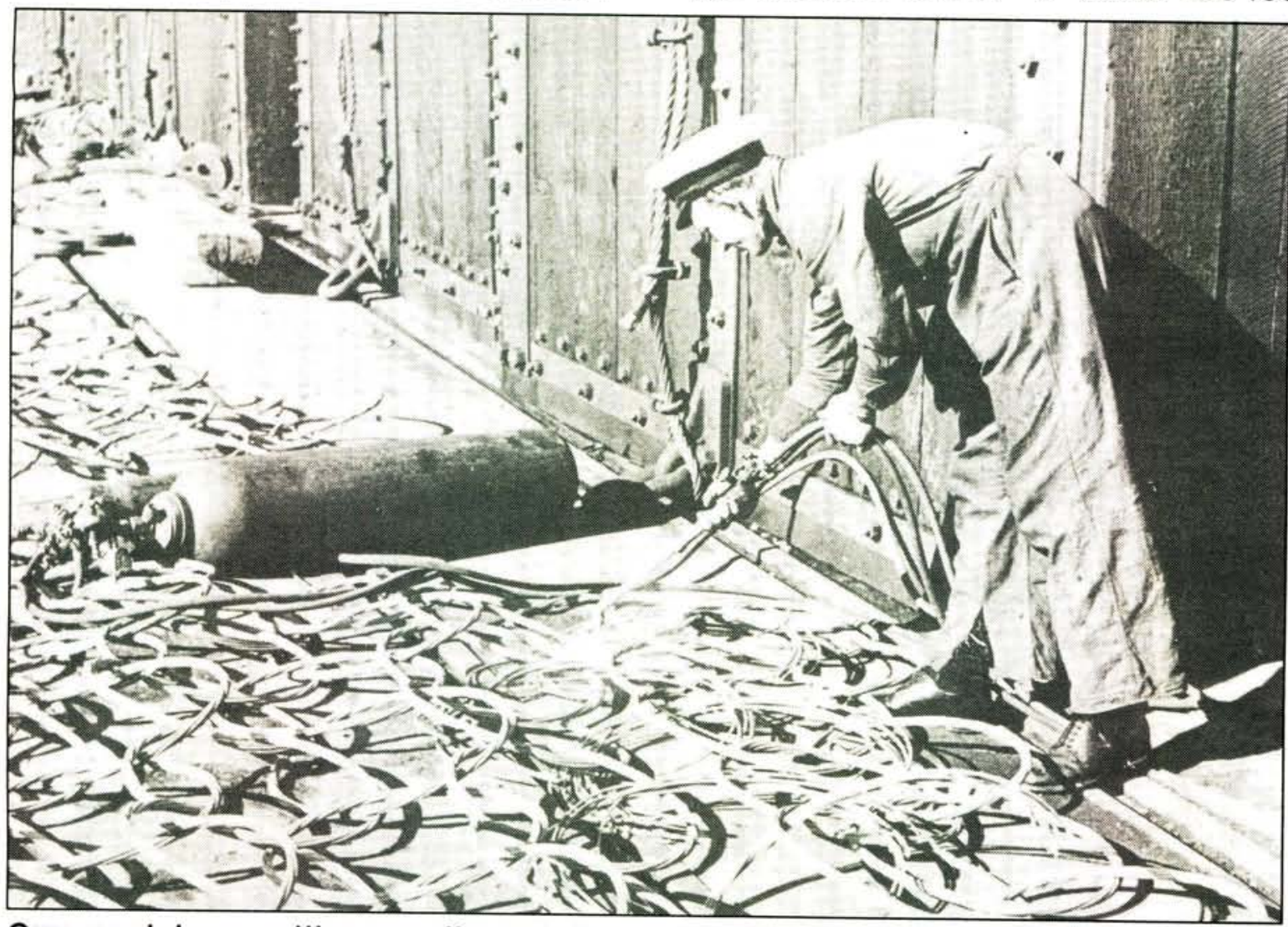

Oxy-acetylene cutting was the quickest method of removing broken or distorted grommets from an anti-torpedo net.

Town to be re-commissioned by a South African crew, already trained in boom-laying, at the end of January. She then returned to Saldanha and relieved BARBRAKE which was then also taken over on 15 February. The laying in its latter stages was therefore carried out chiefly by the SANF under the supervision of RN officers. The total time taken was exactly eight months, west of the northern end of " $C$ " baffle and the entrance therefore faced north and south. The boom was $A / T$ only, flotation being provided by spherical floats instead of the spiked baulks used elsewhere; also, the depth was that of one A/ T net only, which did not reach the bottom except near the shore, so that very little protection was given against midget submarines or human torpedoes. 
The SANF Take Over all Boom Defence Work. Until the middle of 1942 the SA Boom Defences were installed and maintained by SAR \& $\mathrm{H}$ technicians. This was done under the supervision as regards defence requirements, of the SDF which was responsible for the operation of the booms (though, as already stated, other personnel, more suitably placed, provided most of the manpower).

After the great expansion of boom defences was authorised early in that year, it became evident that a special Boom Defence branch of the SDF with its own establishment of trained personnel, storage depots and repair facilities would soon be required. On 10 July the Director, SDF wrote to the Deputy Chief of Staff putting up detailed proposals, most of which were adopted without delay. On 1 September Mr A.G. Jones, on the staff of the Harbour Engineer, Cape Town, who had been placed in charge of this work on the outbreak of war, was transferred to the SANF with the rank of Lt Cdr and became Boom Defence Officer, South Africa. His staff at first was established at; two other officers, 10 senior ratings (as riggers) and 28 Coloured $A B s$; and a crew of one officer and 18 ratings was also allowed for manning one boom vessel when taken over.
Saldanha Bay was chosen as the site for the main storage depot because of the unlimited space available there and also because that port was to have by far the largest boom-defence system. For the time being the headquarters and workshop remained at Cape Town from where parties could be sent to other ports where suitable quanitities of gear were stored for local use. After the completion of the Durban booms, however, two riggers were stationed there permanently to carry out inspections and minor repairs there and at East London and Port Elizabeth.

At first there was the usual difficulty in obtaining suitable personnel, either in the form of men with previous experience or volunteers for training in this work, especially as the establishment was greatly increased when it was decided to take over both "Bar-class" ships, each requiring a crew of 32 . It was also found that the proposed number of riggers sufficed for shore work only and that fourteen more would be required, seven in each ship as part of her permanent complement. By the middle of 1943 most of these had been obtained, but for several months the Boom Defence branch of the SANF could barely cope with its commitments, working seven days a week.

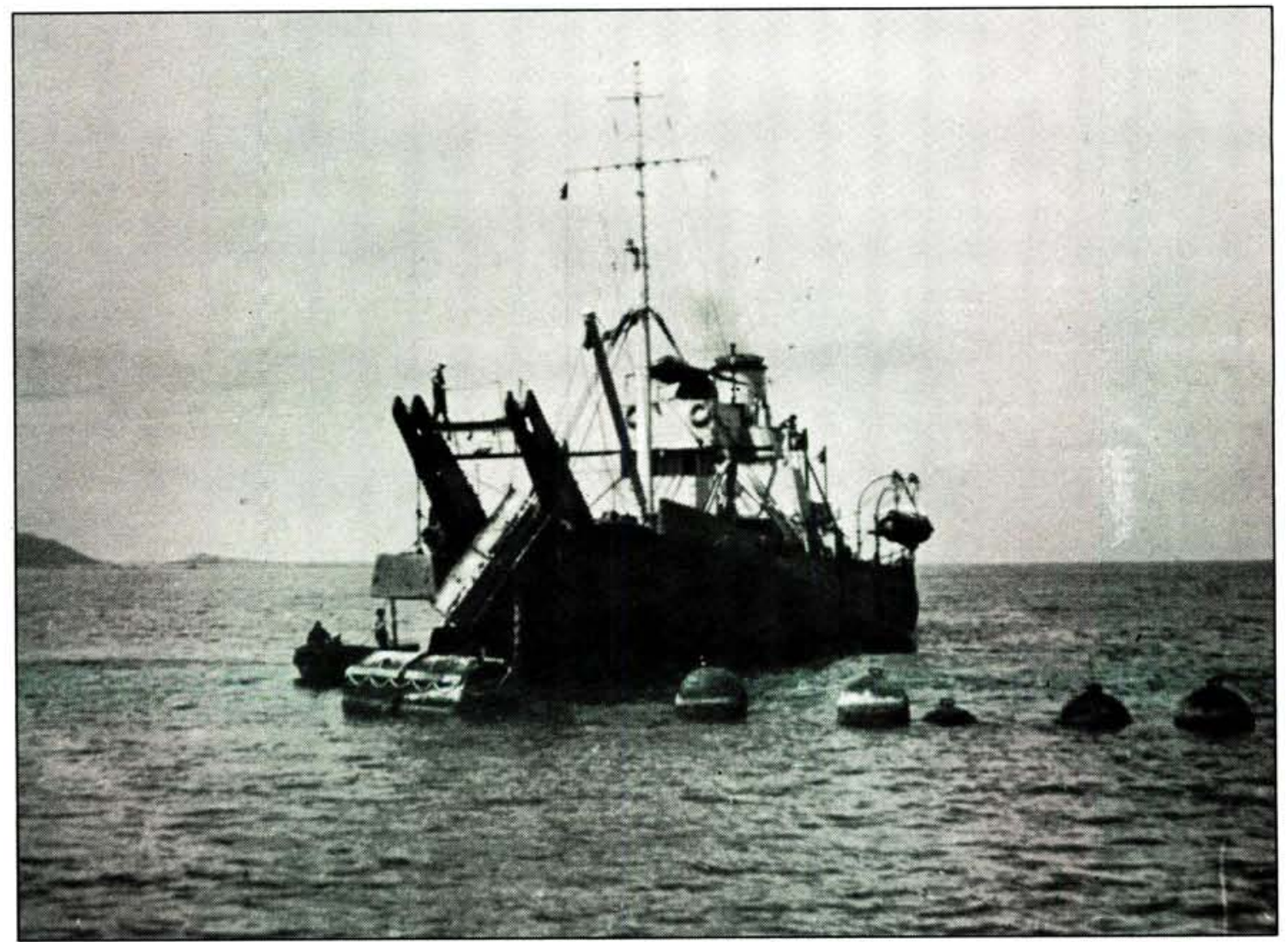

HMSAS BARCROSS (later SAS SOMERSET) at Saldanha. The concrete block hanging from her starboard horn was a clamp used in mooring the trots. 

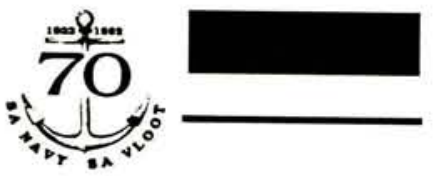

\section{NAVAL TRAINING AFTER 1941}

Training for the SDF during the first two years of the war was somewhat haphazard. From that point it is now proposed to describe the development necessitated by the big influx of recruits which began in the latter half of 1941 .

As to living accommodation, the local Detachment Headquarters could no longer cope with the numbers, although men under training or serving on shore were encouraged to find private lodgings in Cape Town (where the preliminary training of all Europeans (Whites) was carried out); hutments, sufficient for 60 recruits, were
By the middle of 1942, however, these living and training quarters had both become inadequate. A section of Pollsmoor military transit camp was therefore taken over in August and for nearly two years all initial training in discipline and seamanship was carried out there under Lt L.C. Heydenrych. Up to 200 men at a time underwent the course which lasted for one month. This number included the monthly quota of 40 men recruited for $\mathrm{RN}$ service, who were seconded after taking the course and also recruits from the Rhodesias and elsewhere who had joined the RN directly and were trained on its behalf by the SANF.

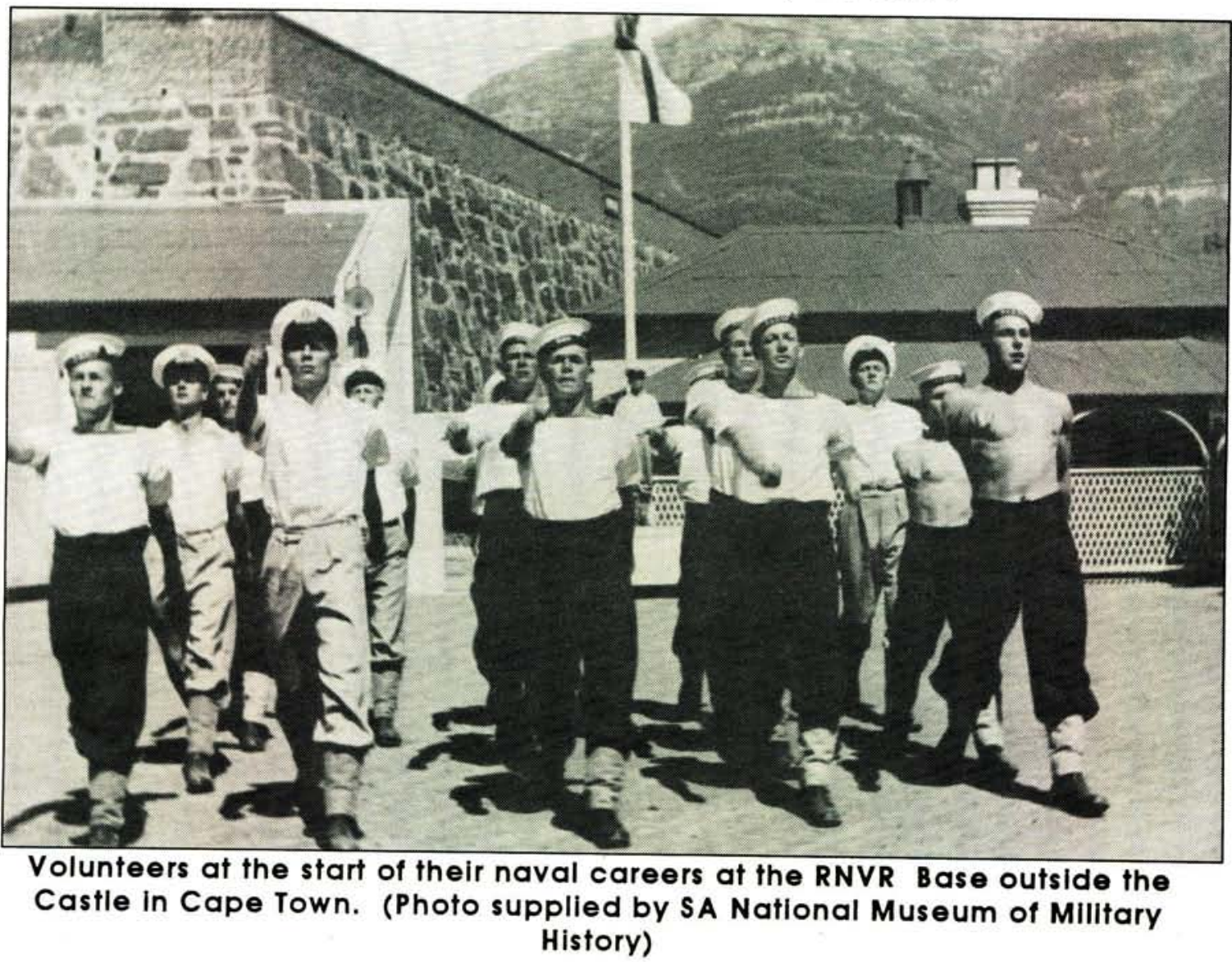

therefore provided near the new graving dock in September. For the actual training, the reduction in the number of RNVR recruits about balanced the increased number of SDF, so that the old RNVR Base near the Castle sufficed for the time being.
Meanwhile, the new naval training base, HMSAS UNITIE, had opened on 4 July under the command of $\mathrm{Cdr}$ W.J. Copenhagen, then CO Cape Town Division, RNVR (SA). When the SANF, of which he automatically became a member, was formed at the end of the 


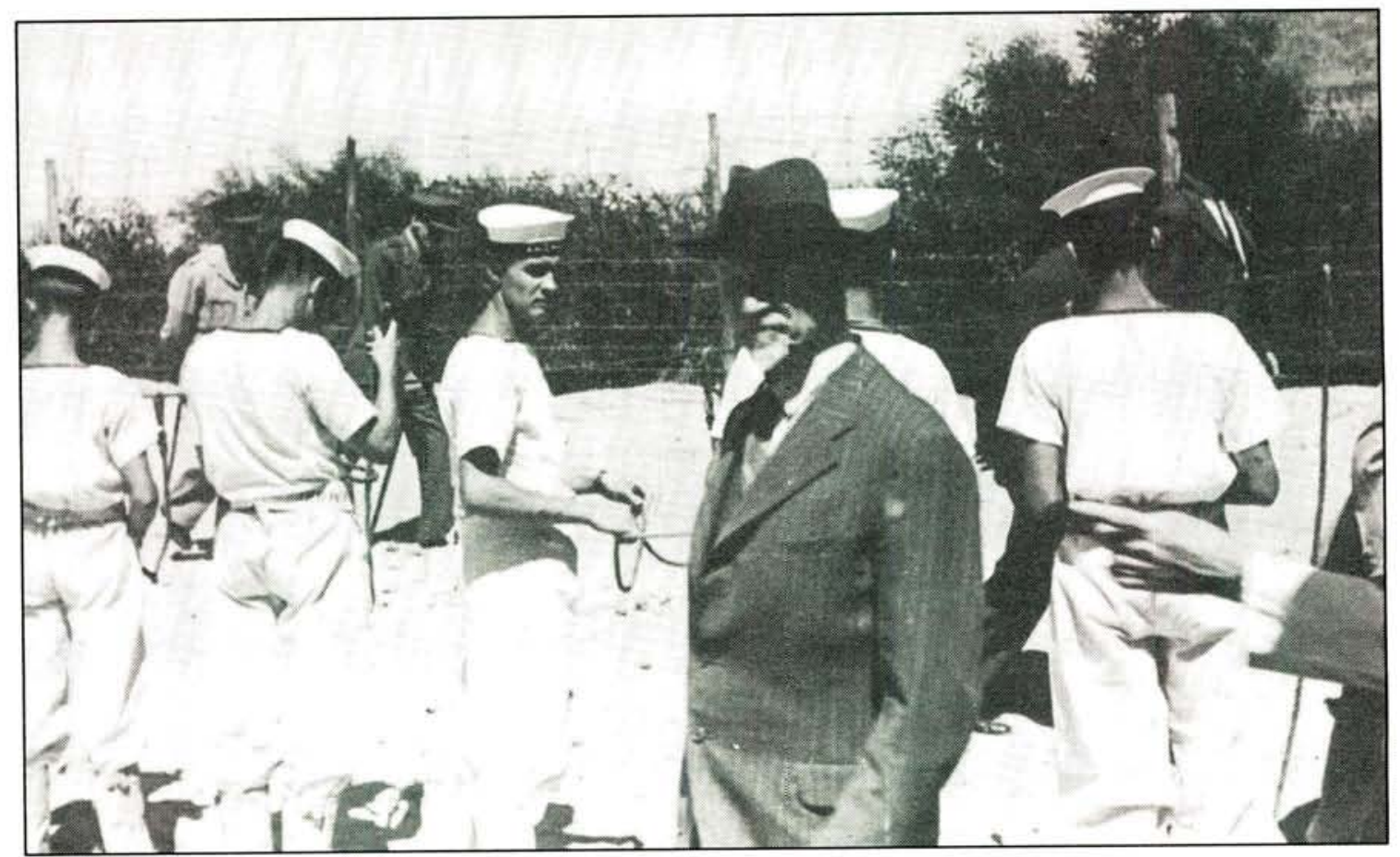

Gen Smuts visiting SA Naval recruits at Pollsmoor.

month, he was also placed in charge of all SANF training. The junior new entries (including the Coloureds at Port Elizabeth) having been satisfactorily provided for elsewhere, it then became possible to concentrate all specialised training in one establishment - moreover, in one built for the purpose, although the living accommodation had to be supplemented by hutments. As well as advancement courses for leading and petty officers' rates being held and seamen gunners, signalmen and telegraphists being trained there, the new base was used, then or later, for many other kinds of instruction. The first of these resulted from the arrival of specialists in $A / S$ Fixed Defences and Controlled Mining in the latter half of 1942; it was not until after these installations had been completed that all training in their use was transferred to Robben Island and Saldanha Bay.

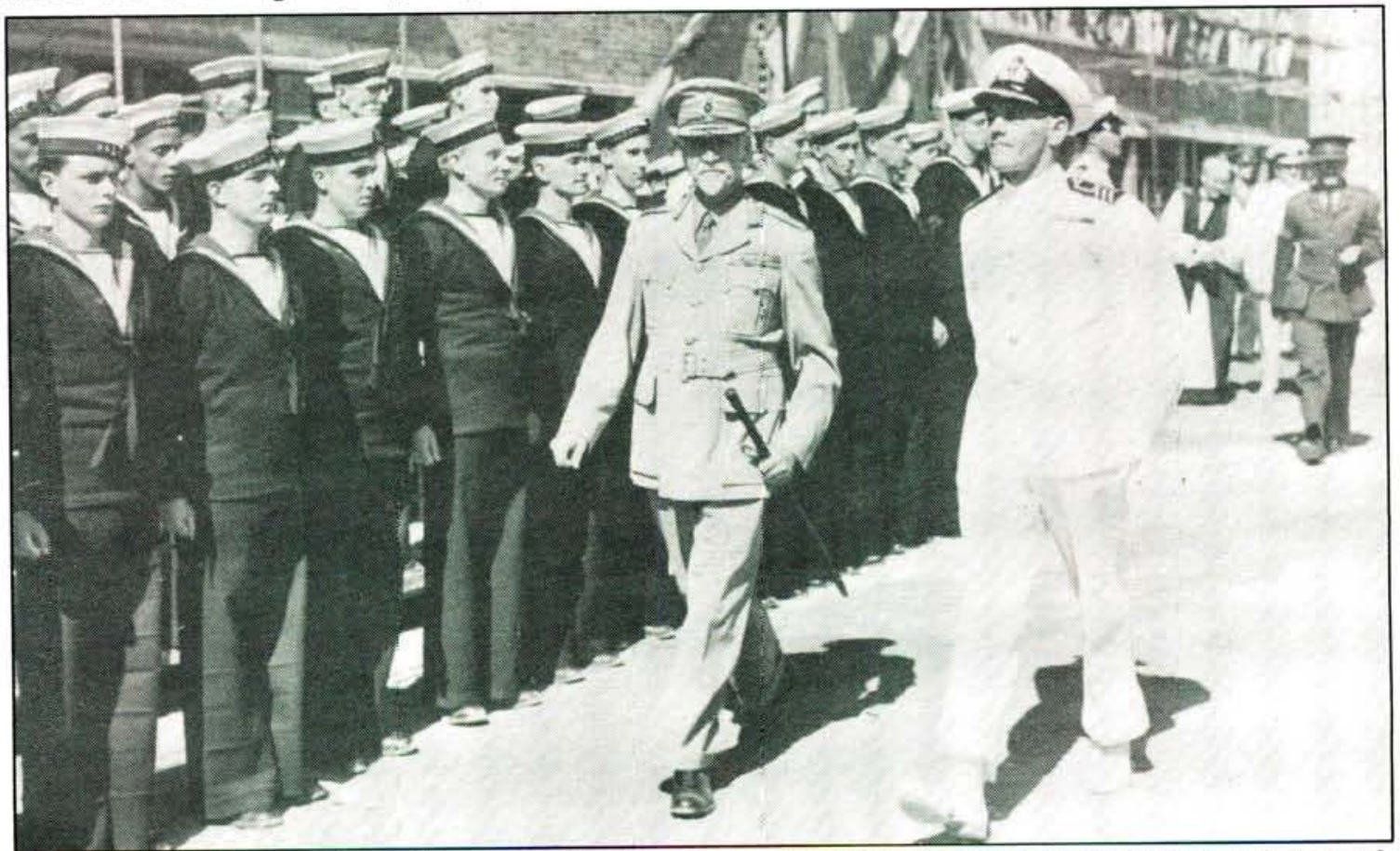

Gen Smuts inspecting the guard of honour after laying the foundation stone of the SA Naval Training Base, HMSAS UNITIE, on 28 February 1942. On his left is Cdr W.J. Copenhagen. 


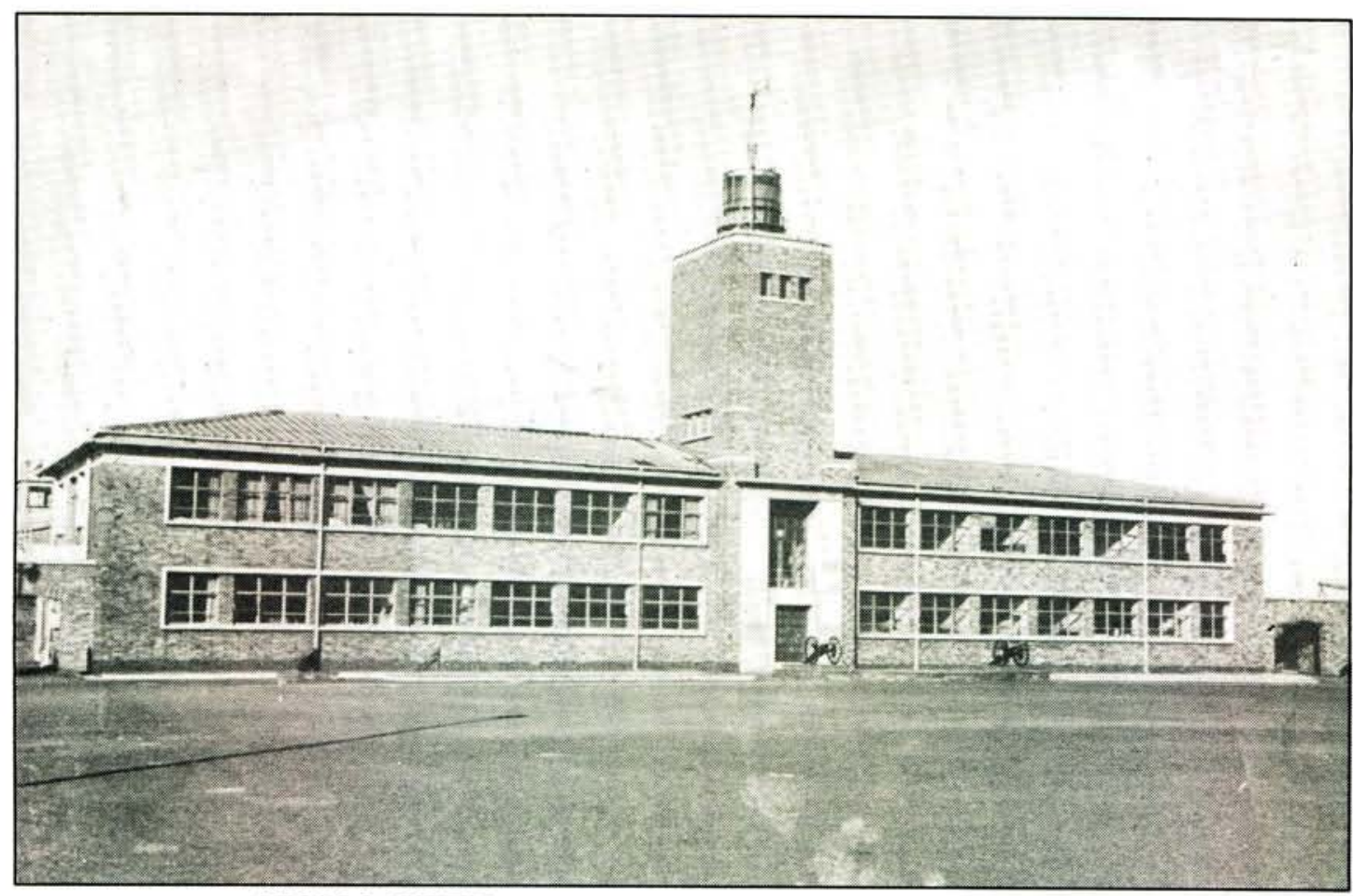

HMSAS UNITIE was commissioned on 4 July 1942.

In 1943, midshipmens' courses began and also navigational instruction and examinations for other officers not previously qualified in this subject. Towards the end of that year, preliminary courses for the newly formed Women's Auxiliary Naval Service were held. In 1944 there were short courses in Radar for some of the officers and men who were to take over the frigates or work the installations in the A/S whalers about to be so fitted. In 1944 also, the anti-submarine school, previously housed by itself in Cape Town docks, was transferred to UNITIE.

\section{TRAINING AT SALDANHA BAY}

When the barracks built for the RN at Saldanha Bay became available for the SANF in May 1944, its advantages over Pollsmoor for initial training became apparent. At Pollsmoor, it was felt, training suffered from the distractions of the neighbouring city of Cape Town; from there also, practical instruction in boatwork entailed the use of land transport and much waste of time. The move was therefore decided upon and the first batch of recruits arrived at Saldanha on 14 June 1944. Soon afterwards, when elementary instruction in gunnery was added, the courses were lengthened to nine weeks, with a corresponding increase in the number under training; this occasionally reached 300 , including "extras", such as a batch of Polish naval cadets. The SANF Initial Training Centre remained at Saldanha Bay until all training was transferred to Durban in 1948.

\section{ROYAL NAVAL TRAINING}

While training for the SANF was thus being placed on a satisfactory basis, the Admiralty decided soon after the formation of the Eastern Fleet early in 1942, that advanced naval training on a large scale should be carried out in the Union of South Africa, thereby making it unnecessary for ratings already serving in the fleet, who would be required to qualify (or re-qualify) for the various specialist branches, to be sent back to the United Kingdom for that purpose. (Had the war continued for longer, it is probable that new entries would also have been trained; but, in the event, the SANF continued to do this for the $R N$ as stated previously).

By the middle of 1942, the building of the main establishment had begun at Wentworth, on the outskirts of Durban. R Adm R.J.R. Scott was appointed Rear-Admiral Training Establishments 
and was installed in an office in Durban to supervise all the preliminary arrangements.

In October 1942, a large hotel at Seaview, near Port Elizabeth, was taken over for the training of cadet ratings as commissioned officers. These were mostly junior RN ratings, including SANF Seconded Personnel; the descendant of the RNVR (SA). It was arranged that members of the SANF proper, who had been recommended for commissions, should also be trained there for the Union Government, but this ceased when courses for SANF midshipmen began at UNITIE in 1943. The RN courses which lasted for 14 weeks, included sea training provided by the SANF in HMSAS AFRICANA or some other vessel based at Port Elizabeth. This establishment, named HMS GOOD HOPE, closed down in April 1944.

By May 1943 the Wentworth establishment was sufficiently advanced to take over the name and functions of HMS ASSEGAI, a naval camp near Pietermaritzburg where a pool of personnel previously had been maintained and some elementary instruction carried out. The new ASSEGAI, designed to accommodate about 2000 officers and men and fitted out for advanced training in nearly every specialist branch, was completed during 1944 but was never fully occupied owing to the unexpectedly early defeat of Japan. At about the same time a large hospital for the RN was completed nearby.

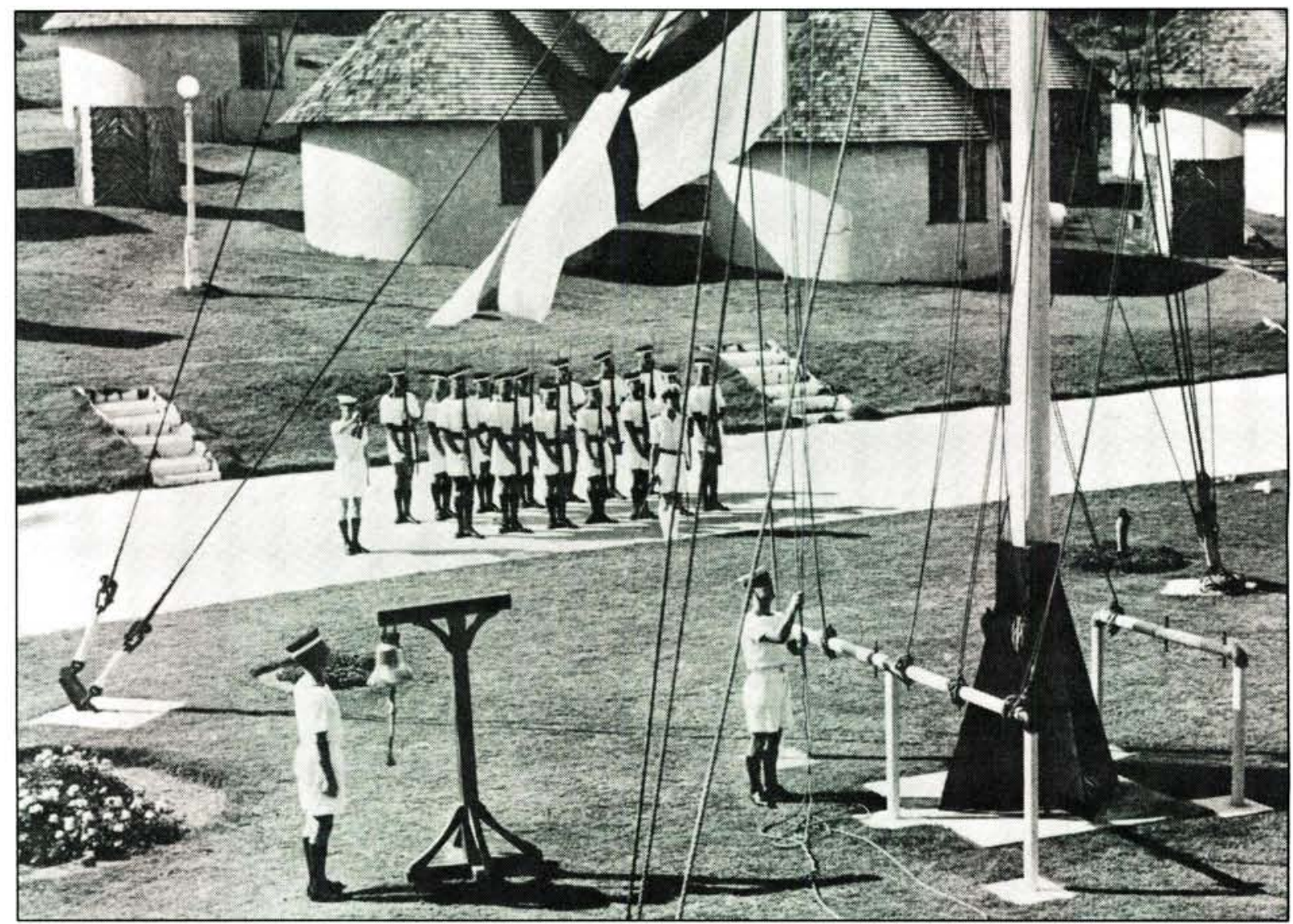

Colours at HMS GOOD HOPE in Port Elizabeth. (Photo supplied by SA National Museum of Military History) 


\section{THE ACQUISITION OF THREE FRIGATES BY THE SA NAVAL FORCES}

The name "frigate", once applied to the cruisers of sailing-ship days, was revived for a class of large anti-submarine vessel which first appeared early in 1943, just as the whaler-type escort vessels, laid down in large numbers in 1939 and 1940, had been given the old class-name of "corvette". The last-named, being very seaworthy for their size and capable of rapid mass-production, filled the bill at that time; but later, as a result of improvements in the U-boats and their tactics, they were found to be inadequate except for escorting the slower convoys. For hunting, especially, something larger and faster was required.

The frigate may be described as a destroyer, shorn of all weapons and other features except those required for killing submarines - no torpedoes, a light gun-armament and only sufficient speed to run down a surfaced U-boat and therefore the more easily and economically produced and manned. In size, it was much the same as the average destroyer so that, as well as having a wide radius of action and good sea-keeping qualities, it had ample carrying capacity for more depth-charges and throwers, as well as any additional anti-submarine weapons which might be and were in fact, introduced later. Compared with a destroyer, the frigate is shorter and beamier. Those first built displaced 1445 tons and had a speed of 21 knots.

The first step towards the provision of frigates for South Africa was taken on 27 May 1944 when the Acting Minister of Defence (Mr F.C. Sturrock, Honorary Commodore SANF) was informed by General Smuts, then in London, that the Admiralty was prepared to place three of these vessels at the permanent disposal of the SANF for employment in Union waters. Of the total of 450 to 500 men required for them, the Admiralty also offered to provide trained South Africans of petty officer rank, then serving with the $R N$, for specialised duties. The immediate object of this offer seems to have been to raise South African naval prestige for recruitment purposes and so obtain a quid pro quo, for the Admiralty at the same time asked for 3600 recruits for service with the RN, spread over the next twelve months.

As the Sixth Armoured Division, then on active service in Italy, had to be kept at full strength, any such contribution was out of the question; even the maximum monthly quota of 40 SANF Seconded Personnel had not been fully forthcoming for some months previously. It would in fact have been difficult to raise crews for the frigates themselves but for the laying-up of minesweepers which took place three months later. With the probability of this reduction in mind, Mr Sturrock suggested that the frigates should be accepted; he also proposed that, to make up for not providing the men asked for, the ships should be made available for service with the Royal Navy anywhere. To this the Admiralty agreed on 13 July and on 22 July the Union Government formally accepted their offer. Shortly afterwards it was stated that the ships would be new ones - of the "Loch-class", then under construction and considerably larger than the existing "River-class" frigates.

The ship's company for the first frigate 10 officers and 120 men - were assembled at Cape Town in September 1944 and embarked on 20 September for the United Kingdom; on 9 November they arrived at Blyth, in Northumberland, where the ship had just been completed; and that afternoon $\mathrm{Lt} \mathrm{Cdr}$ R.P. Dryden-Dymond commissioned her as HMSAS GOOD HOPE - the first South African major war vessel. She then went to Tobermory (in the island of 


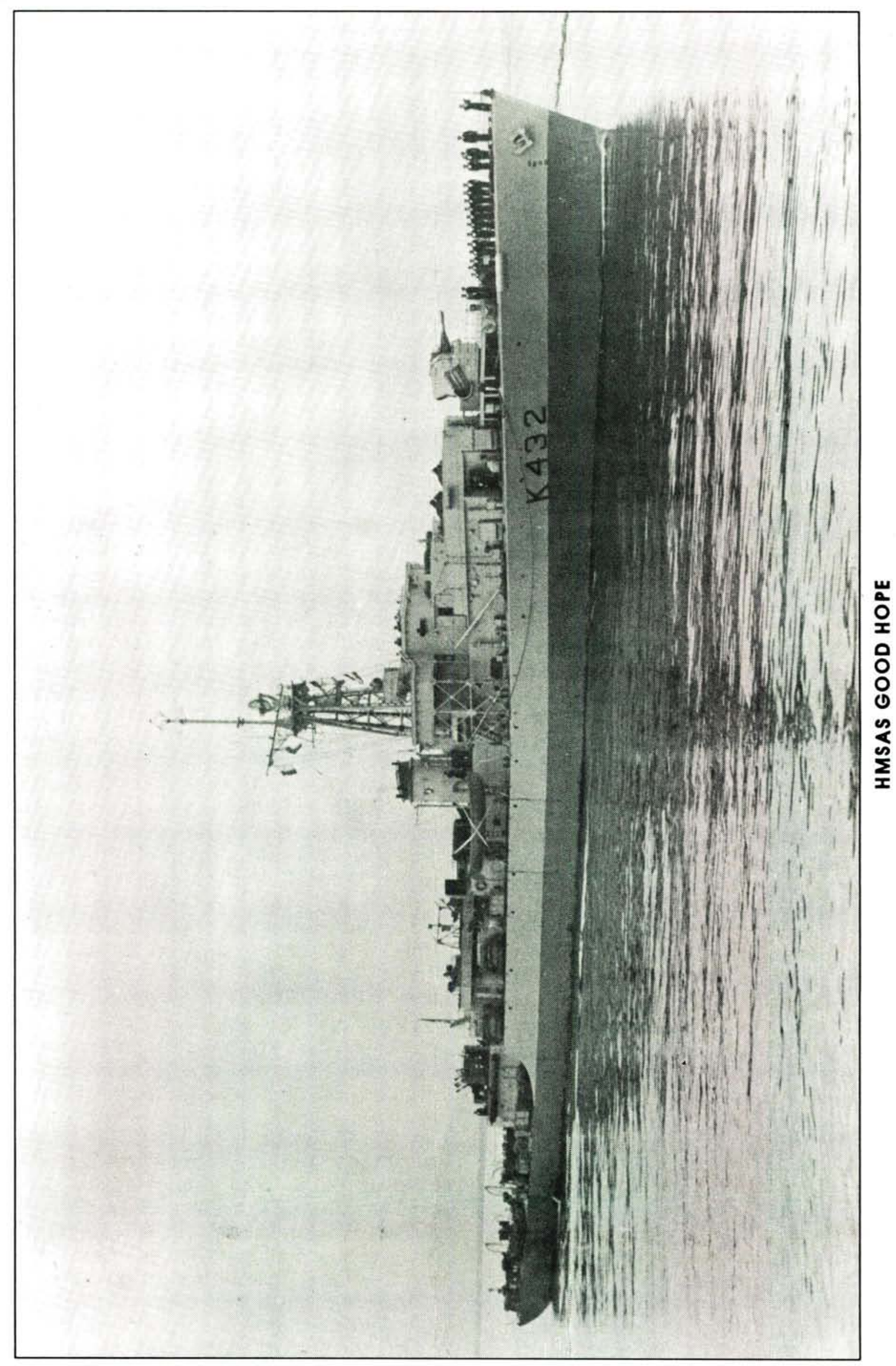


soon afterwards confirmed by instructions from the Commander-in-Chief, Rosyth.

At 15:11, when two miles from the rafts which had been used as a datum point, NATAL obtained and held a good $A / S$ contact. Ten minutes later she fired her first pattern (the main $A / S$ weapon of the frigates was the "Squid" which fired, ahead of the ship, a pattern of six $500 \mathrm{lb}$ time- fused projectiles); much oil and a cylindrical tank, 5 feet long and two feet in diameter, came to the surface. With $\mathrm{A} / \mathrm{S}$ conditions remaining excellent, contact was soon regained and the second pattern, fired at 15:38, brought up more oil and debris. The A/S echo then steadily weakened, finally disap- collected, it did not necessarily follow that the submarine had been destroyed. While NATAL went on her way north to Scapa Floe and thence to Tobermory, a special searching group of $A / S$ vessels left the Tyne for the scene of the action; in almost the exact position reported by the NATAL they located the sunken submarine which, blasted by many depth-charges, soon gave up all the floating evidence required to establish an unquestioned "kill". The first intimation of this was received by NATAL on 19 March in the following signal from the Commanderin-Chief Rosyth :

"Consider evidence now obtalned clearly indicates the attack reported in your 141720 resulted in the

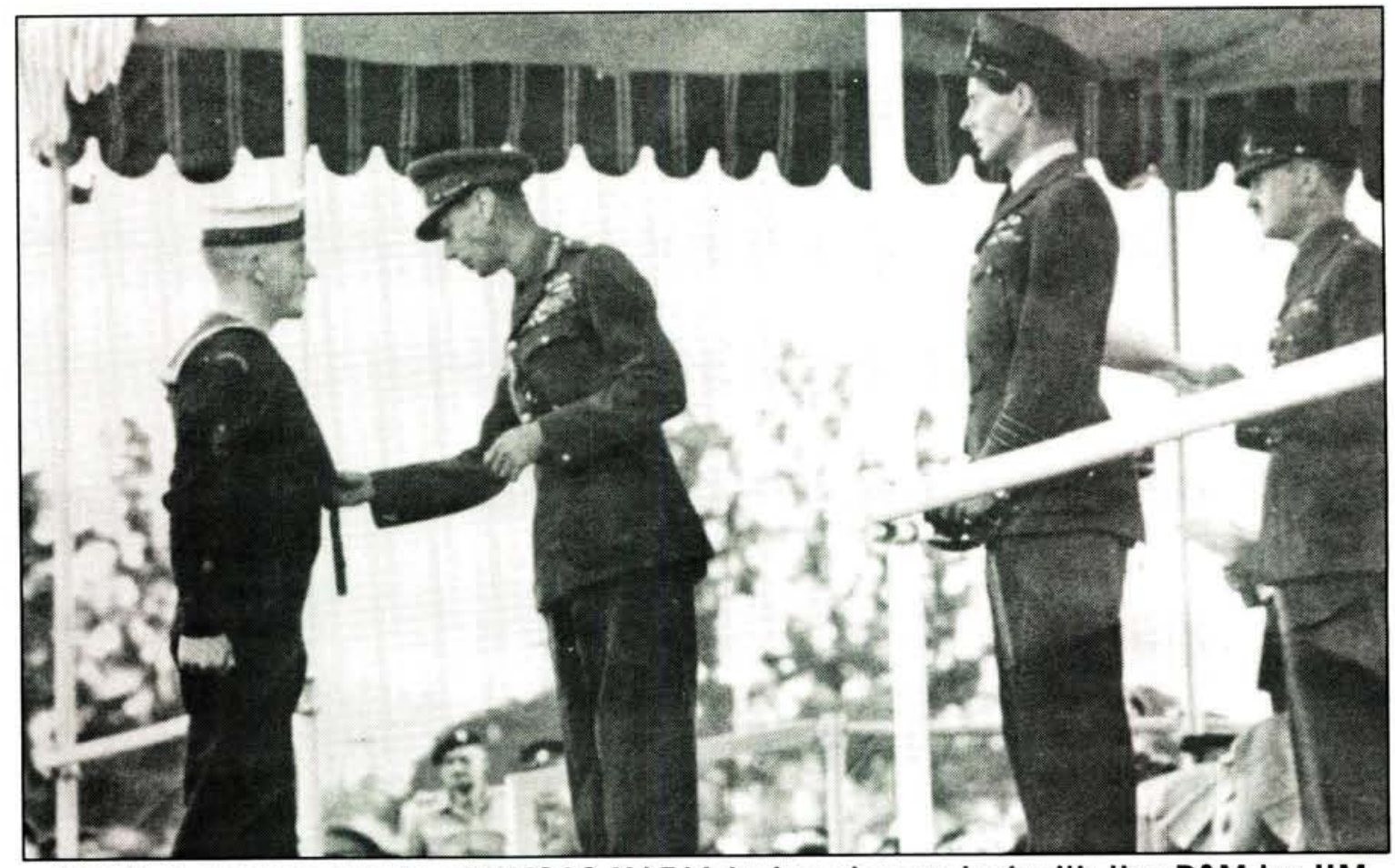

AB Mlchael van Breda of HMSAS NATAL being decorated with the DSM by HM KIng George VI for his part in the sinking of U-714.

pearing at 16:11 when the hunt was broken off. The two ships then carried out a combined search of the area without result. That evening NATAL called at Methil, in the Firth of Forth, where the salvaged tank was landed for examinaiton and the local naval authorities were provided with a full report on the A/S attacks. By this time there was little doubt that the tank was a life-saving apparatus containing a self-inflating dinghy - an item normally supplied to U-boats - but, this would have been carried outside the hull and no other evidence of value had been destruction of a U-boat. Heartlest congratulations on this most successful start of your commission. T.O.O 182354A."

Other messages of congratulation were later received from the Commanders-in-Chief Home Fleet, Western Approaches and South Atlantic Station; from the Admiralty, the Administrator of the Province of Natal and from NATAL's sister ship GOOD HOPE.

As far as is known, this success, in being achieved six hours after leaving 
the builder's yard, established a record for a new ship. It was the more remarkable in that the $A / S$ personnel, as a team, had received only a few day's shore training and, apart from that, the ship's asdic installation (Type 144) was new to all of them. For this action four decorations and five Mentions in Dispatches were awarded, Lt Cdr Hall receiving a bar to the DSC he had won in the Mediterranean in 1941. Among other evidence recovered was a wooden plaque marked " $U$ $766^{\prime \prime}$, suggesting this to be the number of the submarine destroyed. Actually U-766 had been scrapped by the Germans at La Palice prior to the recapture of that port by the Allies in 1944. The submarine sunk by NATAL was later identified as having been U-714.

After her working-up period, NATAL went to the Clyde for boiler-cleaning and on 20 April, off the south-east coast of Ireland, rejoined the 8th Escort Group with which she had already done her group training. In NATAL's absence, the three other ships - also "Loch-class" frigates - had bagged a submarine (U1024) which had surfaced and been abandoned by her crew after a lengthy hunt; she had been taken in tow but had sunk before reaching port. The next fortnight was spent on patrol and escort work in the Western Approaches during which NATAL obtained one promising contact, first by radar and then by asdic, but lost it before an attack could be made.

\section{ARRIVAL OF FRIGATES IN SOUTH AFRICA}

The unconditional surrender of Germany, on 7 May 1945, (the first broadcast ordering German submarines to cease operations was not sent out until 8 May ("VE Day")) found GOOD HOPE and NATAL boiler-cleaning at Greenock. They were immediately taken in hand for tropicalisation and certain other alterations required for service in the Far East. At the request of the Union Government it was agreed soon afterwards that the ships should be routed via the Cape and complete their fitting-out there, thus giving them the opportunity of "showing the flag" in South African ports. GOOD HOPE and NATAL sailed from Greenock on 6 June and on 28 June put into Saldanha
Bay to clean and paint ship after the passage. There they landed 28 South African repatriated prisoners-of-war and embarked the Chief of the General Staff, Sir Pierre van Rynevald, and the Director, SANF. The ships entered the Duncan Dock at Cape Town on 30 June and were formally received by the Acting Minister of Defence, the Commander-in-Chief, South Atlantic (V Adm Sir Robert Durnott), the Administrator of the Cape Province, the Mayor of Cape Town and others. GOOD HOPE then began her fitting-out at Cape Town and NATAL sailed for Durban on 5 July for the same purpose.

The crew for the third South African frigate left Cape Town at the end of February 1945 and their ship was completed on the Clyde six weeks later too late to take part in the war in Europe. She was commissioned as HMSAS TRANSVAAL by Lt Cdr H.E. Fougstedt on 14 May and began her working-up period at Tobermory on 28 May. She left Scottish waters on 8 July, reached Cape Town on 28 July and, after calling at Port Elizabeth and East London, arrived at Durban for fittingout on 9 August. For the short period that they were expected to spend in South African waters, it was arranged that the three ships should remain under the administrative and operational control of the Royal Navy.

\section{OTHER RN VESSELS TAKEN OVER}

As part of the policy for the installation of naval fixed defences, it had been agreed that the vessels required for their maintenance would be taken over from the Royal Navy. As a result, the boom-layers BARCROSS and BARBRAKE joined the SANF early in 1943 and the S/M layer SPRINDRIFT did so in July of that year. Meanwhile HMS MEAD had completed the laying of the A/S loops at Cape Town, Durban and Port Elizabeth; but her transfer was delayed, partly owing to uncertainty as to whether other new loop systems would be installed by the Admiralty. Eventually she joined the SANF on 27 August 1944 when the Union Government took over the hire agreement with her owners, Messis Smith's Coasters.

The paying-off of 19 minesweepers at the end of 1944 and of four $A / S$ vessels 
in the following March, released sufficient personnel to replace those provided for the three South African frigates. In April 1945, with the defeat of Germany and further local naval reductions expected at any time, the Union Government was able to comply with a request for the SANF to man two, or possibly three, more frigates for service on the East Indies Station those ships, however, to remain the property of the Admiralty, similarly HMS SALVESTOR, the salvage ship taken over by a SANF crew at Naples in 1944. The "River-class" frigates TEVIOT and SWALE, which had already been in service for some time, were earmarked for this and the former was commissioned at Cape Town on 10 June by Lt Cdr A.S. Bowyer. She sailed from Durban on 19 June, called at Diego Suarez (Madagascar) and arrived at Colombo on 2 July. There she joined the East Indies Escort Command and immediately began her working-up period which lasted until the end of the month. TEVIOT was at first employed as a link and mark ship on the aircraft route between Colombo and Rangoon. In September she struck an unchartered wreck in Burmese waters, suffering considerable under-water damage. After being repaired at Rangoon she returned to Durban to be paid off there on 21 December.

HMS SWALE was commissioned at Simon's Town by Lt Cdr E.V. Brown on
1 August 1945 and was then employed in the Mombasa area until the end of the year. She was paid off and recommissioned by a RN crew in January 1946.

\section{POST-WAR EMPLOYMENT OF SOUTH AFRICAN FRIGATES}

Of the three South African frigates only NATAL crossed the Indian Ocean. She sailed from Durban on 20 August 1945 and arrived at Colombo, via Diego Suarez, on 1 September. Although the war had ended, it remained necessary for convoys to be escorted through certain mined areas and NATAL was chiefly employed on this duty, between Port Swettenham and Singapore, during September and October. She returned to Durban on $30 \mathrm{No}$ vember and reverted to SANF control.

On 22 August 1945, eight days after "VJ Day", the Union Government informed the Admiralty that they did not wish to become involved in any post-war occupation duties or to send any more men out of the country. They therefore requested that the Admiralty should reconsider decisions taken as to the future employment of the frigates. On account of this, the Commander-inChief South Atlantic held back GOOD HOPE, due to sail for Colombo on 25 August. On 30 August the Union Government compromised by stating that, if the Admiralty so desired, the three South African frigates and the

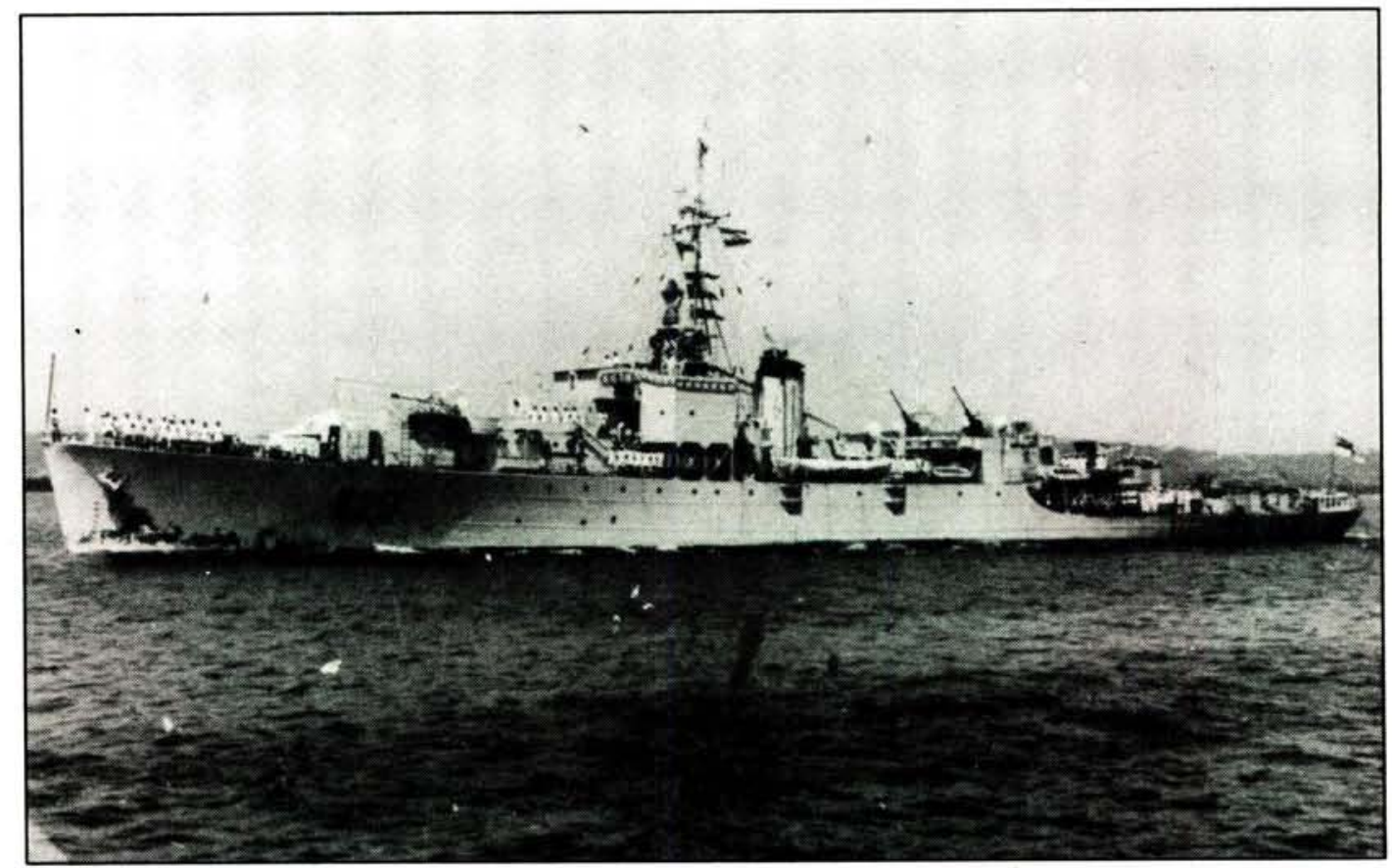

HMS SWALE. 
crews of SWALE and TEVIOT could be employed in Eastern waters for a maximum period of six months after the conclusion of the war. No immediate action was taken, however; TRANSVAAL was then fitting out at Durban; SWALE was being employed at Kilindini; and GOOD HOPE, after doing a trip to Walvis Bay early in September, was temporarily placed under the operational control of the SANF in connection with the ceremonial opening of the new sturrock graving dock at Cape Town, which she was the first ship to enter, on 18 September.

It had been intended to sail GOOD HOPE for Colombo directly after this function, but on 13 September the Commander-in-Chief, East Indies stated that there was no longer any work for her (or for TRANSVAAL, when completed) on his station. GOOD HOPE was therefore sent to Kilindini from where she towed the South African LL minesweeper IMHOFF, which had suffered a series of breakdowns on her return from the Mediterranean, to Durban; arriving there on 4 October, GOOD HOPE was placed under the permanent control of the SANF next day and similar action was taken with TRANSVAAL on 3 November. Soon after the three frigates were relinquished by the RN, the two Bofors AA guns, mounted on the quarterdeck of each ship
When being prepared for the Far Eastern war, were removed.

Ever since the end of the war in Europe, the Defence Department had been faced with the problem of repatriating large numbers of service personnel from Italy and the Middle East. While the war in the Far East continued, very little shipping space could be made available and the best that could be done was to concentrate most of the men in transit camps in the Suez area. Even after the fall of Japan, there was no immediate prospect of providing the sea transport required, so the employment of the South African frigates to ease the position was considered. The first proposal, made at the end of August, was that GOOD HOPE and TRANSVAAL should be used as accommodation ships at Beira, to facilitate the return of personnel by air. The prospect of the two ships lying in a tropical port for an indefinite period, manned only by skeleton crews so as to provide the necessary living space, was most unattractive, not only as regards mechanical maintenance but also for morale especially as these new ships were to be the main units of the future peacetime navy. Fortunately the objections of the Director SANF were accepted and the scheme was dropped.

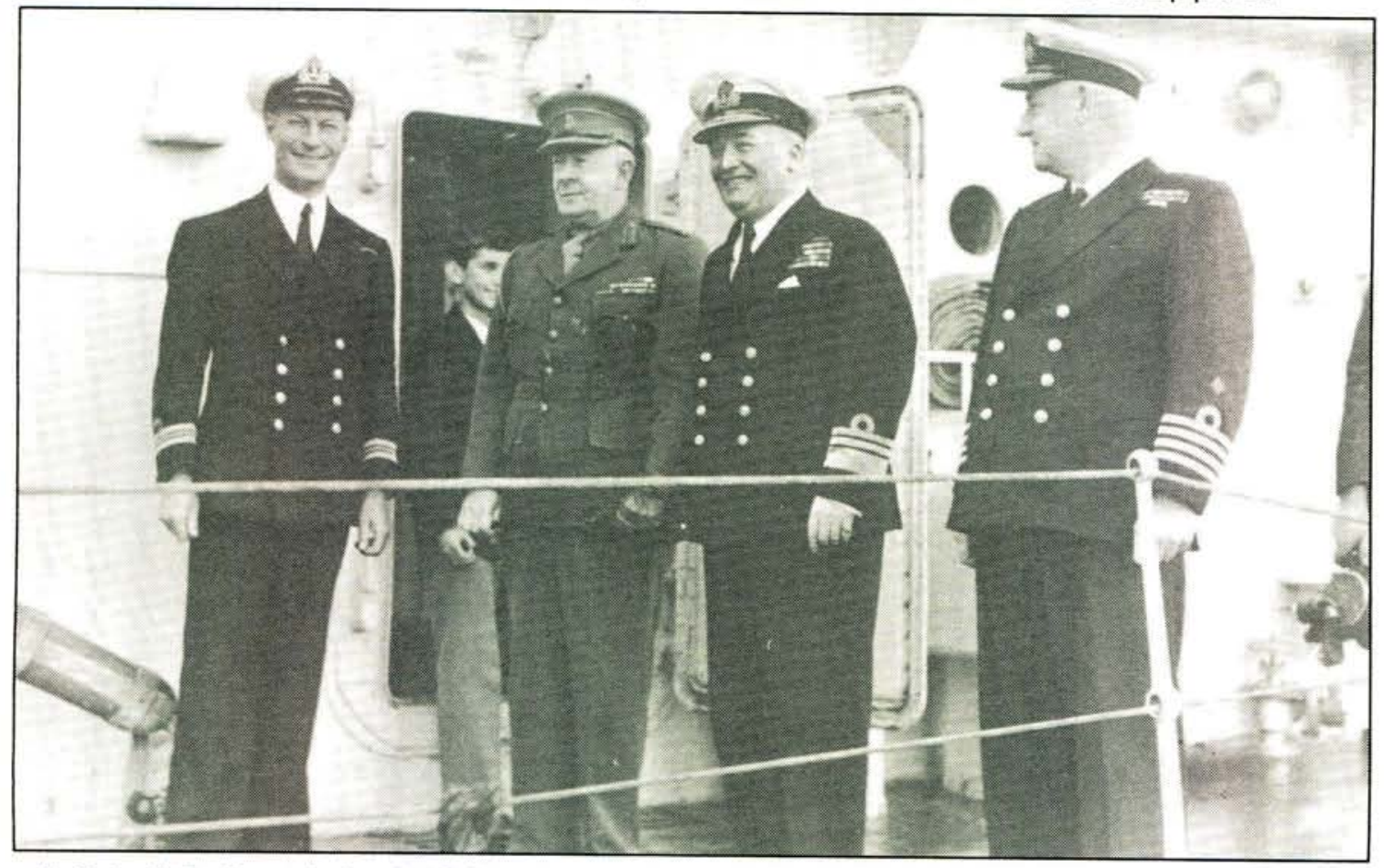

Lt Cdr H.E. Foughstedt (CO) with Brig B.F. Armstrong, V Adm Sir Robert Burnett (C-in-C South Atlantic) and Capt J. Dalgleish (Director SANF) on board HMSAS TRANSVAAL after the ship's arrival in Table Bay Harbour. 
In October it was decided, after some discussion, that the ships themselves should be used for transporting troops from Egypt, although as regards the numbers conveyed, this could be little more than a gesture. With their ship's companies reduced from 130 to 45 the bare minimum for a long passage GOOD HOPE and TRANSVAAL sailed from Durban on 5 November, fuelled at Aden and arrived on 19 November at Suez, where they each embarked six officers and about 94 other ranks. The return passage, in good weather, was entirely satisfactory, good use being made of the army specialists - particularly the cooks - and the ships berthed in Durban on 5 December.

NATAL, having completed her service with the Royal Navy on 30 November, was included in the second transport trip for which the three ships sailed from Durban on 18 December. For this, Lt Cdr Fougstedt of TRANSVAAL became Senior Officer in place of $\mathrm{Lt} \mathrm{Cdr}$ Dymond, who had left GOOD HOPE just previously. This second operation, which repatriated about 300 service personnel, also took about a month and was favourably reported on by the ships' captains and the senior officers taking passage.

On the third and last trip. NATAL developed a defect and had to return from Kilindini, but the other two ships brought their quotas of men to Durban early in March.

Thereafter, during the demobilisation period, the three frigates remained somewhat undermanned, with many changes of personnel, until Permanent Force crews could be assembled.

\section{NARRATIVE OF BARBRAKE}

The return of the last four South African ships from the Levant in December 1945 is described in the Mediterranean section. Only one other ship returned after them - HMSAS BARBRAKE, early in 1946. As is recorded in the chapter on Boom Defences, the Union Government agreed, in November 1944, to lend her and her SANF crew to the Admiralty for service on the East Indies station.
The transfer took place on 27 Janaury 1945 and the boom-layer, commanded by Lt F.M. Kamke, was inspected by the Commander-in-Chief, South Atlantic on 30 January 1945. She sailed from Simon's Town on 3 February, called at Durban, Beira, Diego Suarez, the Seychelles and Addu Atoll and arrived at Trincomalee on 23 March. The next three months were spent in the Bay of Bengal and off the coast of Ceylon where BARBRAKE was chiefly employed in lifting and laying moorings; with Trincomalee as her base port, she visited Madras, Colombo, Coconada, Akyab and also Chittagong where, at the end of April, she played a prominent part in laying a submerged pipeline - a difficult operation because of the strong current - for which she received the congratulations and thanks of the local naval authorities.

On 20 July 1945 BARBRAKE arrived at Rangoon where, during the next three and a half months, her work included the removal of parts of the Japanese boom defences and general work on buoys and moorings in the river channel. On 8 August her First Lieutenant, Lt $\mathrm{J}$. Liddle, was accidently killed when a cable parted on the fo'c'sle. At the end of November she recrossed the Bay of Bengal, called at Trincomalee and Colombo and returned to South Africa by the same route as followed on the way out. While on her way down the Natal coast she found the $A$ / $S$ vessel BLAAUWBERG, broken down and towed her to East London. BARBRAKE arrived at Simon's Town on 12 January 1946 and soon afterwards reverted to the control of the SANF of which she remained a laid-up unit.

A lesson learned from BARBRAKE's service in Indian waters was that her complement was insufficient. The tropical conditions and lack of fresh provisions on the long passages, covered at an average speed of less than seven knots, caused a good deal of minor illness, especially among the stokers. Reliefs usually being unobtainable, riggers and seamen had to lend a hand with the coalfiring. In similar ships of the RN on this service, not only were larger complements allowed but additional stokers were also provided for long passages. 


\section{CHAPTER VIII}

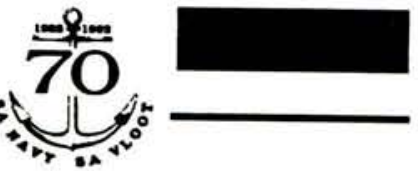

\section{CONCLUSION}

A suitable epitaph to our whalers and rawlers as war vessels, is contained in he last "contact letter" received from t Cdr John Fairburn, Commanding he naval base at Saldanha Bay in 945 :-

"One of the saddest sights imaginable is the Reserve Fleet swinging at their moorings below the Naval Office nothing is so forlorn as a dead ship. To board them is to be reminded of the wild and woolly days on the South Afrlcan coast. If those ships could talk, theirs would be an interesting story tales of the "phoney war" when OOSTEWAL and SWARTBERG disorganised the Port of Cape Town by keeping up a long running commentary on their first efforts to sweep, using the Port RT-wave to do it and ending with the classic phrase: "Am closing down now - the hands have gone to dinner"; stories of the Cape Agulhas minefleld, of the mining of Cape Town, of rescues off
Cape Polnt and of valuable convoys safely dellvered. To them must go the honour of belng the birthplace of the South African Navy and for that reason alone, regardless of others, South Africa has cause to thank them and to say "well done"."

So ended the South African naval war effort, unprepared for and starting almost from zero, but ending as a fair contribution to the Allied cause, considering the population and resources of this country.

Except as an academic component of grand strategy, sea-power and all that it entailed began as a closed book to the Minister of Defence and his Department and remained very much on the top shelf in the years which followed. Indeed there was a general feeling in the Service itself, especially in the early days, that a navy was looked upon as an expensive nuisance which must be

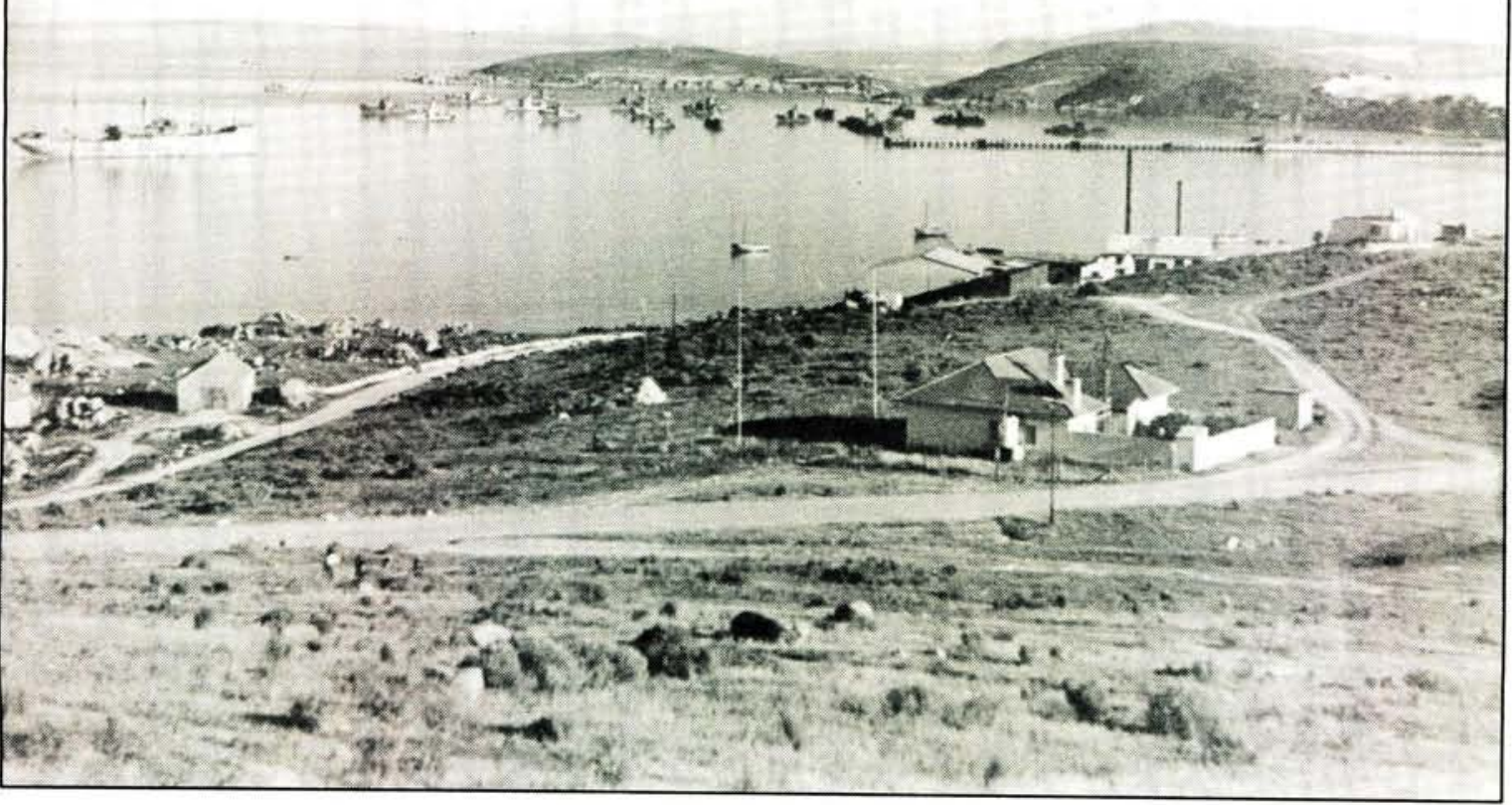

The Reserve Fleet at Saldanha In 1945. 
confined within as narrow limits as possible and the less heard of it, the better. Probably this feeling was exaggerated and the Defence Department's apparent attitude was the only one possible in view of its complete ignorance of sea-going matters.

The failure at a later date to keep in close touch with local developments, combined with the increasing probability of enemy attacks is, however, more difficult to excuse. A striking example of this occurred when FieldMarshall Smuts visited Durban in June 1942. He had not visited the port for some time, but had recently returned from Britain where, among high places, the Battle of the Atlantic was causing more anxiety perhaps than any other aspect of the War.

Before landing, the Minister's plane circled over the roadstead where 50 ships were at anchor - a number which had been about the average for several months previously and the protection of which, with the meagre resources available, had been the major headache of the local navy since the beginning of the year. On arrival, he called together the Fortress Commander, the South African Officerin-Charge and the Commodore- inCharge, Royal Navy. He expressed both surprise and concern at what he had seen in the anchorage and warned these officers that they must keep very much awake. It was as though the Minister of Transport had addressed some of his engine-drivers, cautioned them as to the seriousness of railway accidents and told them to keep a good look-out for signals.

The one person holding high office who evinced a practical interest in naval matters was Mr F.C. Sturrock, whose influence could only be indirect, except when he was carrying out the duties of Acting Minister of Defence and who had, in any case, an important department of his own to administer. Nevertheless, many obstacles were overcome largely due to his efforts. Also, his personal interest and encouragement were most beneficial to morale; it is good for any fighting service to feel that it is, at least, somebody's step-child.

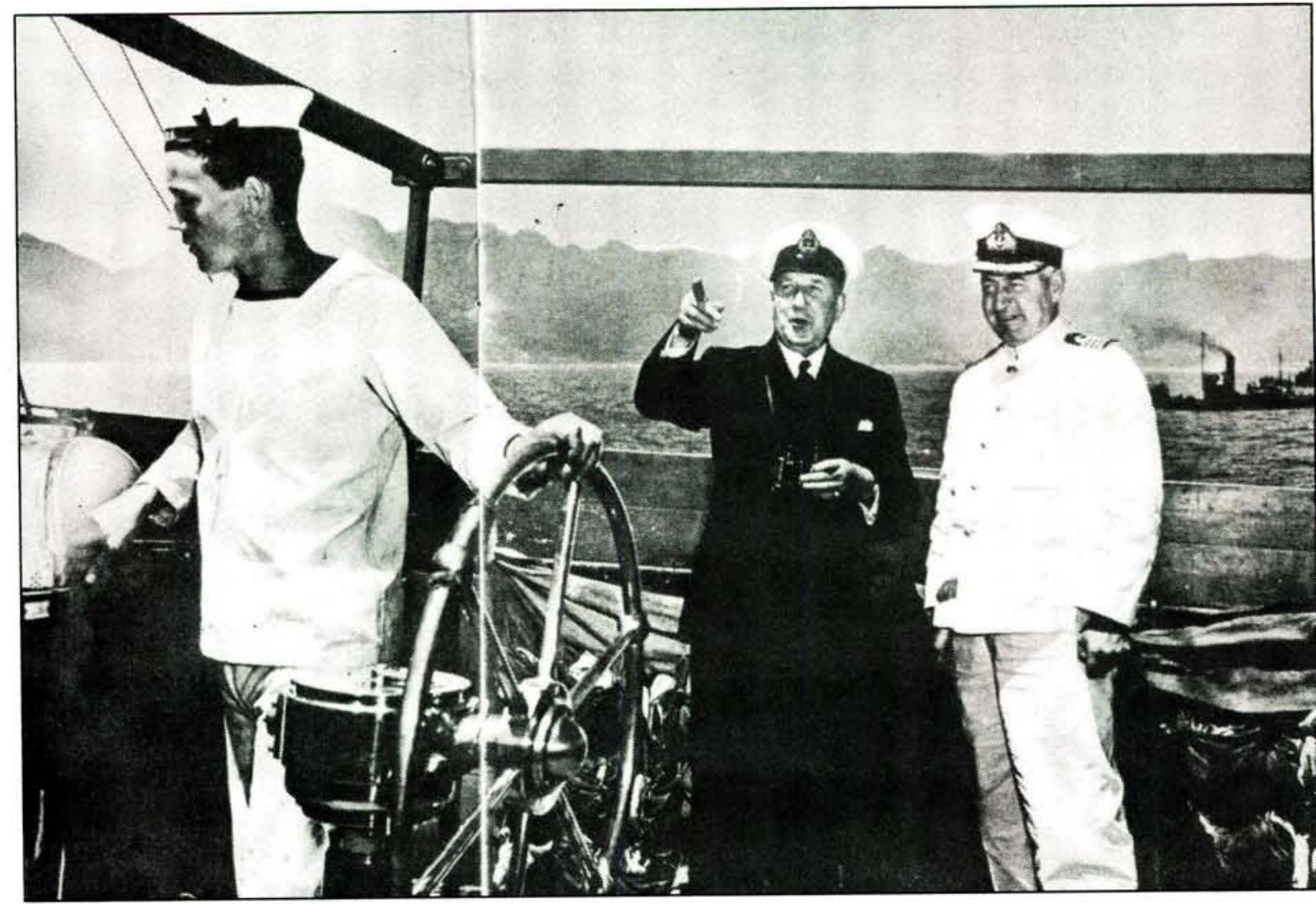

Cdre the Hon Claud Sturrock, MP, Minister of Rallways and sometime Acting Minister of Defence, with Capt (later Cdre) J. Dalgleish. 